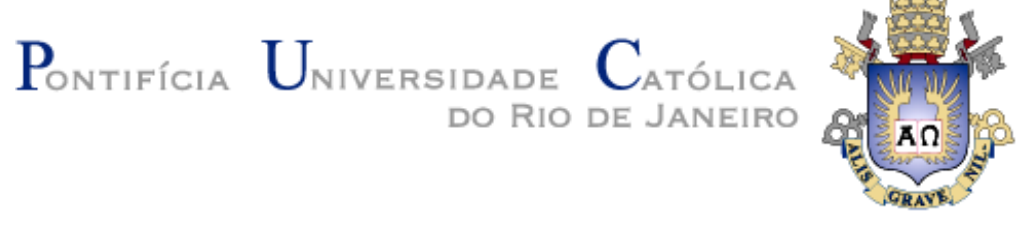

Adriana Maria Ribeiro Gil Ferreira

\title{
UMA ANÁLISE HERMENÊUTICA ACERCA \\ DO PRECONCEITO E DO DIÁLOGO \\ NA EDUCAÇÃO
}

Tese de doutorado

Tese apresentada como requisito parcial para obtenção do grau de Doutor em Educação pelo Programa de Pós-graduação em Educação, do Departamento de Educação da PUC-Rio.

Orientador: Prof. Ralph Ings Bannell 


\section{Adriana Maria Ribeiro Gil Ferreira}

Uma análise hermenêutica acerca do preconceito e do diálogo na educação

Tese apresentada como requisito parcial para obtenção do grau de Doutor pelo Programa de Pósgraduação em Educação do Departamento de Educação do Centro de Teologia e Ciências Humanas da PUC-Rio. Aprovada pela Comissão Examinadora abaixo assinada:

Ralph Ings Bannell Orientador Departamento de Educação - PUC-Rio Profa. Sonia Kramer Departamento de Educação - PUC-Rio

Profa. Rebeca Furtado de Melo Colégio Pedro II

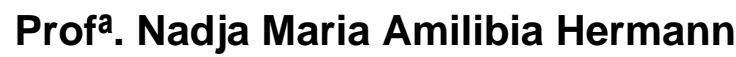
Universidade Federal do Rio Grande do Sul

Profa. Fabiano de Lemos Britto Universidade do Estado do Rio de Janeiro

Prof ${ }^{\mathrm{a}}$ Monah Winograd Coordenadora Setorial do Centro de Teologia e Ciências Humanas

PUC-Rio

Rio de Janeiro, 25 de junho de 2020. 
Todos os direitos reservados. É proibida a reprodução total ou parcial do trabalho sem autorização da universidade, da autora e do orientador.

\section{Adriana Maria Ribeiro Gil Ferreira}

Graduou-se em Pedagogia na UERJ (Universidade do Estado do Rio de Janeiro) em 2008. Concluiu o mestrado em Educação pela PUC-Rio (Pontifícia Universidade Católica do Rio de Janeiro) em 2011. É professora do primeiro segmento do Ensino Fundamental no Colégio Pedro II.

Ficha Catalográfica

Ferreira, Adriana Maria Ribeiro Gil

Uma análise hermenêutica acerca do preconceito e do diálogo na educação / Adriana Maria Ribeiro Gil Ferreira; orientador: Ralph Ings Bannell. - 2020.

$170 \mathrm{f.} ; 30 \mathrm{~cm}$

Tese (doutorado) - Pontifícia Universidade Católica do Rio de Janeiro, Departamento de Educação, 2020.

Inclui bibliografia

1. Educação - Teses. 2. Educação. 3. Diálogo. 4. Preconceito. 5. Compreensão. 6. Hermenêutica. I. Bannell, Ralph Ings. II. Pontifícia Universidade Católica do Rio de Janeiro. Departamento de Educação. III. Título.

CDD: 370 
Aos meus amados filhos, Alice e Francisco. 


\section{Agradecimentos}

O presente trabalho foi realizado com apoio da Coordenação de Aperfeiçoamento de Pessoal de Nível Superior - Brasil (CAPES) - Código de Financiamento 001.

Ao meu orientador, professor Ralph Ings Bannell, pelas significativas conversas que temos mantido desde o mestrado, dentro das disciplinas acadêmicas e grupos de estudos. Obrigada, por toda a sua dedicação e generosidade.

Ao CNPq e à PUC-Rio, pelos auxílios concedidos, sem os quais este trabalho não poderia ter sido realizado. O presente trabalho foi realizado com apoio da Coordenação de Aperfeiçoamento de Pessoal de Nível Superior - Brasil (CAPES) - Código de Financiamento 001.

A todos os professores e funcionários do Departamento de Educação pelos ensinamentos e pela ajuda.

Ao querido professor Marcelo Andrade, in memoriam, por tudo que me ensinou e ainda tem me ensinado, sobretudo, por meio de sua exemplaridade.

Aos professores Nadja Hermann, Rebeca Furtado, Fabiano Lemos e Sonia Kramer, que participaram da Comissão Examinadora.

Aos meus colegas da PUC-Rio. Em especial minhas grandes amigas, Yrama Fernandes e Camila Leporace. Foi um grande presente da vida ter encontrado vocês.

Aos meus colegas do maravilhoso Colégio Pedro II, que tem sido meu local de trabalho e de formação.

A todos os meus amados alunos. Obrigada, por me permitirem fazer parte da história de vocês. 
À minha mãe por todo esforço e cuidado que dedicou a mim e a minha irmã. Obrigada, por tudo que fez pela gente.

Aos meus sogros, Eliana e Paulo, avós dedicados e amorosos, sempre presentes e dispostos a ajudar. Agradeço, também, pelos deliciosos almoços de domingo e pela companhia reconfortante de toda a família Gil.

Aos meus filhos, que me trazem toda a alegria e esperança e que me tornam mais forte. Obrigada, por me fazerem experimentar emoções que eu desconhecia e me fazerem sonhar ainda mais.

Ao meu amado Paulo não só pela parceria e apoio, mas por me encorajar diante dos desafios. Sou grata, também, pelas conversas e ideias que me ajudaram ao longo deste trabalho. 


\section{Resumo}

FERREIRA, Adriana Maria Ribeiro Gil; BANNELL, Ralph Ings. Uma análise hermenêutica acerca do preconceito e do diálogo na educação. Rio de Janeiro, 2020. 170 p. Tese de Doutorado - Departamento de Educação, Pontifícia Universidade Católica do Rio de Janeiro.

O presente trabalho se situa no campo da Filosofia da Educação e tem como tema norteador as contribuições que o pensamento hermenêutico pode oferecer para os debates acerca do preconceito e do diálogo nos processos de formação humana. Acreditamos que o modo como Hans-Georg Gadamer apresenta a formação do horizonte compreensivo dos indivíduos e sua possibilidade de expansão e transformação representa uma virada no modo como temos entendido o papel dos preconceitos desde a Aufklärung. Nesse sentido, buscamos apresentar nesse trabalho como esse modo de considerar os preconceitos, que são inerentes à compreensão humana, pode nos fornecer uma base mais sólida para uma formação que privilegie o diálogo e a abertura entre os indivíduos em seu constante processo de formação.

\section{Palavras- chave}

Educação; diálogo; preconceito; compreensão; hermenêutica; Hans-Georg Gadamer 


\section{Abstract}

FERREIRA, Adriana Maria Ribeiro Gil; BANNELL, Ralph Ings (advisor). A hermeneutical analysis concerning prejudice and dialogue in Education. Rio de Janeiro, 2020. 170 p. Tese de Doutorado - Departamento de Educação, Pontifícia Universidade Católica do Rio de Janeiro.

The present work is situated in the field of Philosophy of Education and has got as its main theme the contributions that hermeneutical thought can provide for the debates concerning prejudice and dialogue in the processes of human formation. We believe that the way in which Hans-Georg Gadamer presents the formation of the horizon of understanding of the individuals and its possibility of expansion and transformation represents a turning point in the way we have been understanding the role of prejudices since the Aufklärung. In this sense, we seek to present in this work how does this way of considering prejudices, which are inherent to human understanding, can provide us with a solid ground to a formation that privileges dialogue and openness among individuals in their constant process of formation.

\section{Keywords}

Education; dialogue; prejudice; understanding; hermeneutics; Hans-Georg Gadamer

\section{Sumário}


1. Introdução 11

1.1. Gadamer e o contexto de produção de sua obra 20

1.2. Verdade e Método l: uma breve introdução 33

2. Apresentação dos conceitos fundamentais 47

2.1. A Aufklärung e o pensamento kantiano: razão e 49

2.2. preconceito 55

2.2.1. Gadamer e a crítica do "preconceito contra o preconceito" 61

2.3. Os preconceitos de autoridade e os preconceitos por 66

2.4. precipitação 70

2.5. A reabilitação da autoridade e da tradição na 78

2.6. hermenêutica

Distância temporal e história efeitual

2.6.1 Horizontes históricos e fusão de horizontes

Diálogo como fusão de horizontes: Gadamer e o diálogo 87

2.7. verdadeiro 89

2.8. A proximidade entre Gadamer e Buber - Sobre a experiência 93

2.9. do tu 101

$\begin{array}{lll}2.9 .1 & 102\end{array}$

3. Sobre as condições para o diálogo: como ficam as 108

3.1. tensões e os conflitos?

A retomada de Platão em Gadamer 109

3.2. A Alegoria da Caverna sob uma perspectiva gadameriana 116

$\begin{array}{lll}3.2 .1 & \text { A experiência educacional } & 126\end{array}$

3.3. Uma breve incursão na crise contemporânea da escola no 135

3.3.1 contexto brasileiro: duas tendências que se polarizam Sobre o planejamento do futuro na educação

3.4 A ideia de tolerância em Gadamer

Educação estética: como ela se relaciona com a ética? $\quad 150$

4. $\quad$ O conceito de jogo: por que Gadamer considerou o jogo 161

5. como o modo próprio de ser da obra de arte? 166

Perspectivas para uma educação hermenêutica: a 
urgência do diálogo

Conclusão

Referências Bibliográficas 
E porque não tem vista, logo se acostuma a não olhar para fora.

E porque não olha para fora logo se acostuma a não abrir de todo as cortinas.

E porque não abre as cortinas logo se acostuma acender mais cedo a luz.

E a medida que se acostuma, esquece o sol, esquece $\mathrm{o}$ ar, esquece a amplidão.

Marina Colasanti, Eu sei, mas não devia 


\section{1 \\ Introdução}

A crise atual na educação não é uma exclusividade de nosso país, na verdade, ela é considerada como um fenômeno mundial, como já foi observado por autores como Rui Canário (2006) e Saviani (2014 e 2017), que se dispuseram a pensar não apenas os rumos da educação tal como ela está instituída, mas, para além disso, o próprio sentido das instituições de ensino que compõem um determinado ideal global de educação escolar. No contexto da educação brasileira, é notório que essa crise ganha algumas especificidades. Ao observarmos as pesquisas realizadas no campo da Educação, que se propõem a observar a implementação e os efeitos das políticas de governo (ESTEBAN, 2009), vemos que no nosso país o agravamento da crise se deu, sobretudo, com a ainda recente ampliação de vagas na educação pública. Cabe, portanto, salientar que um efetivo programa de universalização do acesso à escolarização no Brasil é algo que só foi implementado nas últimas décadas. É importante que se tenha todo o cuidado de não se fazer afirmações definitivas sobre o sucesso ou insucesso de um projeto tão recente, pois isso constituiria uma precipitação. Como observa Oliveira (2007), os problemas que a educação vinha enfrentando podiam ser mais facilmente justificados quando quem ganhava o estigma do fracasso nas instituições de ensino era justamente àquela pequena parcela de alunos oriundos das camadas populares. A situação de pobreza desses alunos era constantemente utilizada como uma explicação simbólica para não haver saída para a tal exclusão. Essa explicação, por fim, acabava por torná-los responsáveis pelo seu próprio insucesso. Com a democratização do acesso à educação, o problema se torna ainda mais visível por atingir um percentual cada vez maior de alunos. Além disso, a demanda por mais escolarização se fez sentir também nas etapas posteriores ao Ensino Fundamental, fazendo com que o locus da crise se ampliasse até abarcar todos os níveis do sistema de ensino do país. As instituições, então, se veem obrigadas a buscar estratégias para regular o fluxo desses alunos e, com isso, intensificam-se os debates a respeito da educação pública e do papel atual que ela assume na nossa sociedade. Importantes pesquisas se dedicam a compreender melhor o problema sob diferentes aspectos: o da organização do currículo escolar, das políticas educacionais, da formação dos 
professores, das avaliações internas e externas, da inserção de novas tecnologias, das relações dos multiculturais, entre outros.

É evidente que para promover o aprendizado de um público tão diverso, as instituições precisaram entrar em um processo de reformulação - pelo qual elas ainda passam com inúmeras dificuldades - algo que acabou causando certa instabilidade e até mesmo questionamentos quanto à viabilidade desse projeto de democratização da educação escolar. E, em meio a tal reformulação, por um lado, passou-se a denunciar a perda de qualidade como resultado da perda de rigor, por outro, questionou-se a capacidade das instituições em dialogar com a diversidade dos alunos e atender as suas demandas. Assim, possíveis causas da crise começaram a ser apontadas, dentre elas: os mecanismos de exclusão que se engendram no interior das instituições de ensino, a falta de preparo dos professores e gestores para lidar com as diferenças e as desigualdades, a falta de investimento financeiro adequado, a baixa escolaridade das famílias desse novo contingente de alunos, o deslocamento da violência urbana para o interior do espaço escolar, o bullying, a perda de sentido da formação - uma vez que o diploma já não garante a inserção no mercado de trabalho, a falta de interação com os novos recursos tecnológicos, ou mesmo o mau uso das novas tecnologias disponíveis etc.

Diante da crise mencionada, é possível observar nos debates públicos sobre a educação duas tendências, que não esgotam, evidentemente, a multiplicidade de visões sobre a questão, mas que apontam para duas direções diametralmente opostas: 1) a que requisita uma maior rigidez das instituições de ensino e de seus mecanismos de disciplinarização, classificação e seleção; e 2) a que compreende que as instituições de ensino nos moldes em que elas se configuram hoje são, em sua essência, opressoras, seletivas e excludentes, e que elas serviriam prioritariamente para reproduzir um modelo de sociedade igualmente excludente e opressivo.

Faço aqui uma ressalva à primeira tendência que, mesmo não tendo ainda ganhado espaço no consenso acadêmico, tem se mostrado cada vez menos marginal. Ela se vale de uma visão ingenuamente idealizada acerca de uma época em que as instituições de ensino gozariam de prestígio social, o qual, por sua vez, seria consequência, sobretudo, da excelência das metodologias tradicionais e de suas rigorosas práticas disciplinares, mas que, na verdade, resultam em um 
processo de homogeneização. Como observa Rui Canário, ao fim e ao cabo, esse modelo de escola "permitiu passar de formas de ensino individualizadas (um professor ensina a um aluno) para modos de ensino simultâneo (o professor ensina a uma classe, considerada como uma entidade única)" (2006, p. 30).

É importante adiantar que, evidentemente, a menção a essas duas tendências constitui uma generalização, com um objetivo indicativo. $\mathrm{O}$ espaço desse trabalho não nos permitiria esgotar todas as suas variações, portanto, utilizo aqui a estratégia de acentuar essas tendências com objetivos didáticos, sabendo que o que encontramos de fato nas análises acerca do atual quadro da educação no país são perspectivas muito mais amplas e diversas.

Como alternativa a essa polarização, gostaríamos de delinear uma terceira vertente analítica, na qual nos parece mais razoável inserir uma parcela significativa daqueles que se propõem a repensar a educação sem renunciar à sua legitimidade institucional. Essa terceira forma de abordagem comporta a possibilidade de colocar como tarefa para o campo da educação a revisão de suas próprias concepções acerca do ser humano e de seu modo de se relacionar com o mundo, algo que está na base de todos os debates acerca dos desafios que hoje estão postos. Por abrir espaço para o questionamento acerca da existência de uma racionalidade universal, que se forma fora dos seus contextos históricos, essa terceira abordagem é o lugar onde se propõe uma análise mais pormenorizada dos fundamentos que sustentam o fazer educativo. Neste trabalho, propomo-nos seguir essa vertente que cremos não se submeter a qualquer custo às instituições tradicionais de ensino e suas respectivas práticas, mas que também não as rechaça por completo, por acreditarmos que essas instituições podem ser ainda espaços privilegiados para a ampliação de horizontes compreensivos. Acreditamos, além disso, que é possível criar as circunstâncias para que os indivíduos se formem uns com os outros colocando em diálogo os conhecimentos prévios que trazem da tradição à qual se vinculam. Temos em vista, portanto, uma escolarização que promova um autoquestionamento e uma autocompreensão que rompa com os dogmatismos que impedem uma relação aberta com outras possibilidades de formação.

Com este fim, trazemos para o debate, nesse trabalho, as contribuições que a hermenêutica filosófica de Hans-Georg Gadamer pode dar para pensar o sujeito e seu horizonte histórico de formação. Entendemos que a hermenêutica filosófica 
pode nos auxiliar no aprofundamento da análise histórico compreensiva, transpondo-nos de uma mera análise conceitual para as condições históricas de sua manifestação. Acreditamos que a hermenêutica de Gadamer possa nos trazer boas contribuições na medida em que ela nos auxilia a ver na crise um momento fecundo para o questionamento acerca dos conceitos que permeiam todo o fazer educativo.

Como nos fala Gadamer: "Ao filósofo cumpre a clarificação dos conceitos, não a apresentação de um novo fundo de conhecimento obtido através da investigação empírica" (p.97, 2001). Nesse sentido, nossas perguntas se dão no sentido de aprofundar conceitos que hoje têm sido recorrentemente utilizados nesse contexto de debate acerca da diversidade de culturas, das possibilidades para o diálogo e do reconhecimento das diferenças.

Já de partida, numa leitura hermenêutica, temos uma radical transformação no modo como compreendemos os indivíduos. No lugar de uma racionalidade pretensamente neutra que poderia ver de fora a si mesma e dialogar com outras racionalidades, o que vemos, em vez disso, é a primazia dos horizontes históricos que condicionam e ao mesmo tempo habilitam o indivíduo no questionamento de si próprio. Esses horizontes constituem o que o indivíduo pensa de si mesmo e carregam consigo os preconceitos herdados da tradição a qual esse indivíduo se encontra vinculado. Assim, o presente estudo se propõe analisar os questionamentos do filósofo Hans-Georg Gadamer acerca daquilo que ele denominou como sendo o caráter "essencialmente preconceituoso de toda a compreensão" (GADAMER, 1997, p.406). Uma vez que, para Gadamer, aquilo que orienta de início nossa compreensão são fundamentalmente os preconceitos herdados, nosso objetivo é apresentar o modo como o autor nos leva a uma visão mais aprofundada acerca de tais preconceitos, assim como a possibilidade e, ao mesmo tempo, os limites de sua transformação na nossa relação com a própria tradição.

Partindo do entendimento de que a palavra preconceito carrega consigo uma conotação extremamente negativa e controversa, tomaremos o cuidado de aqui, já de início, esclarecermos qual o propósito do seu emprego no contexto da obra de Gadamer e, por conseguinte, na nossa. Nosso objetivo é justamente conduzir as antecipações e projeções - que o nosso uso cotidiano da palavra nos permite fazer 
- a uma lida mais autêntica com esse termo, sem a qual seria infrutífero nosso debate.

Gadamer inicia sua reflexão acerca dos preconceitos na segunda parte da obra Verdade e Método I. A palavra "preconceito" (Vorurteil) não teria de antemão uma conotação negativa ou positiva. Em alemão "vor" significa adiante de, antes de, "pré-", e "Urteil" significa "juizo". Preconceito seria então um juízo prévio sobre algo. Para entender por que razão Gadamer chama a atenção para a conotação neutra desse termo, é necessário voltar à descrição ontológica de Heidegger da compreensão ${ }^{1}$, à qual Gadamer adere e torna uma das bases principais de seu pensamento.

A partir da leitura de Gadamer, vemos que o modo como atualmente concebemos o preconceito tem sua origem no contexto da Aufklärung ${ }^{2}$, quando se pretendeu colocar sob o jugo da razão todos os saberes que a tradição nos oferecia, saberes esses que correspondiam a todo o conjunto de crenças, dogmas e verdades historicamente legadas e propugnadas por aqueles que se concebiam como tutores da humanidade. Segundo Gadamer, no contexto da Aufklärung, a própria palavra preconceito passou a ganhar uma conotação preponderantemente negativa. A palavra preconceito se tornou sinônimo de julgamento precipitado, de falso saber, de algo que impediria a nossa boa compreensão das coisas e, por fim, impediria nossa boa relação com aqueles que são diferentes de nós, ou que de alguma forma não são abrangidos por padrões previamente concebidos de uma normalidade. Por esse motivo, o preconceito deveria ser vigorosamente combatido, evitado, camuflado e, se possível, eliminado.

Evidentemente, Gadamer não desconsidera que preconceitos possam se referir a juízos arbitrários e falsos saberes ${ }^{3}$. De acordo com o autor, há aqueles preconceitos que, de fato, limitam nossa compreensão acerca de algo. Contudo, ele irá demonstrar como a própria ideia de uma supremacia da racionalidade com relação aos dogmas da tradição se expressa também sob a forma de preconceitos e que, por isso, ela não pode servir como um patamar a partir do qual se pudesse

\footnotetext{
${ }^{1}$ Adentraremos esta questão a partir da página 28, na introdução da primeira sessão deste trabalho.

${ }^{2}$ Optamos neste trabalho por seguir a edição que utilizaremos do livro Verdade e Método I e não traduzir o Aufklärung para o português. Contudo, devemos informar ao leitor que se trata do movimento intelectual que se iniciou na Europa no século XVIII e que ficou conhecido no Brasil por Iluminismo, Século das Luzes, Ilustração ou Esclarecimento.

${ }^{3}$ Gadamer utiliza em algumas passagens os termos preconceitos verdadeiros e preconceitos falsos. Reconhecemos que este uso é controverso, contudo, não é de interesse desse estudo pormenorizar essa questão.
} 
decidir sobre que conhecimento é legítimo e que conhecimento é ilegítimo. Em vista disso, ele defende que:

Como questão central de uma hermenêutica verdadeiramente histórica, a questão epistemológica fundamental, pode ser formulada: em que pode basear-se a legitimidade de preconceitos? Em que se diferenciam os preconceitos legítimos de todos os inumeráveis preconceitos cuja superação representa a inquestionável tarefa de toda razão crítica? (GADAMER, 1997, p.416)

Considerando, então, a necessidade de se elucidar o modo como se estrutura a nossa compreensão e como atuam dentro dela nossos preconceitos, nosso objetivo é buscar saber se é possível, a partir da interpretação apresentada por Gadamer, oferecer para a educação uma reflexão mais rigorosa acerca do tema dos preconceitos, a fim de lidar com o problema de maneira menos precipitada, para não dizer "preconceituosa". Pois, como ressalta o autor, deve-se evitar cair na contradição da Aufklärung do "preconceito contra os preconceitos", o que é absolutamente central na relação pedagógica. Para Gadamer, são os nossos preconceitos que, em princípio, orientam nossas ações na relação com as coisas e as pessoas. Ainda que esses preconceitos se mostrem ilegítimos e problemáticos, eles são sempre o ponto de partida para a nossa relação com aquilo, ou com aqueles, que desejamos conhecer. Qualquer tentativa de aboli-los se configuraria, então, em um sério problema, pois, além de ser uma empreitada fadada ao fracasso, ela, como veremos mais adiante, pode gerar mais silenciamento do que ampliação do conhecimento. Desse modo, a pergunta fundamental que nos guiará durante todo o trabalho é: Como, então, a educação é capaz de formar a "razão crítica", referida por Gadamer nesses termos tradicionais, capaz de superar inumeráveis preconceitos ilegítimos? Pois, não se trata de fazer uma apologia do preconceito, ou de simplesmente admitir que os indivíduos não sejam responsáveis pelos preconceitos herdados de sua tradição. Muito pelo contrário, nossa intenção é a de buscar meios de confrontar aqueles preconceitos que já se mostraram ilegítimos, mas que permanecem orientando muitas de nossas concepções e práticas.

Ao nos aproximarmos da hermenêutica gadameriana, percebemos que o caminho apontado por Gadamer não é o de olharmos simplesmente para uma subjetividade que manifesta seus preconceitos, mas para o próprio contexto de aparição dos mesmos, que seria, inclusive, responsável pela formação processual 
dessas mesmas subjetividades. Nesse sentido, o horizonte histórico a que os indivíduos dão voz, nos dá muito mais pistas a respeito de como transformar e formar subjetividades do que as próprias subjetividades em formação. Desse modo, diante das manifestações dos preconceitos que já se mostraram ilegítimos, podemos ir à busca de seu horizonte de sustentação e, assim, questionar esses mesmos preconceitos de forma mais radical.

Em vista de nossos objetivos, dividiremos este estudo em duas seções. $\mathrm{Na}$ primeira, apresentaremos como Gadamer, a partir de uma concepção ontológica da compreensão, que ele encontra em Heidegger, chega ao problema do preconceito. Nessa mesma seção, seguindo a interpretação do autor, iremos apresentar como o questionamento acerca dos preconceitos aparece na Modernidade, tomando como referência principal o texto Resposta à pergunta: o que é o esclarecimento? de Immanuel Kant. Em seguida, apresentaremos como Gadamer caracteriza o conceito de diálogo e como nossos preconceitos se manifestam durante a realização do diálogo, entendido como fusão de horizontes.

O diálogo, por seu turno, é um tema clássico no interior da história da filosofia, por isso, o sentido do conceito de diálogo comporta diferentes interpretações. Mesmo sua significação na filosofia de Platão já é bastante controversa, como nos mostra Gadamer em alguns de seus inúmeros ensaios sobre o autor clássico grego ${ }^{4}$.

Para Gadamer, é precisamente no diálogo que reside a ação do autêntico educar. O educar que extrapola a ação intencional de um indivíduo sobre o outro é, antes de qualquer coisa, algo que o próprio indivíduo realiza sobre si mesmo. (GADAMER, 2000), pois educamos a nós mesmos com o outro no diálogo. Nas palavras de Hermann:

O diálogo não é um procedimento metodológico, mas se constitui na força do próprio educar - que é educar-se - no sentido de uma constate confrontação do sujeito consigo mesmo, com suas opiniões e crenças, pela condição interrogativa na qual vivemos. (HERMANN, 2002, p.94)

Gadamer adota um olhar bastante peculiar a respeito daquilo que normalmente compreendemos por educar, ampliando assim o significado do termo. Gadamer privilegia o caráter de interlocutor do professor com relação ao

\footnotetext{
${ }^{4}$ Sobre esse assunto $C f$. GRONDIN, Jean. (org) Platão como Portraitista. In O pensamento de Gadamer. Tradução Enio Paulo Gichini - São Paulo: Paulus, 2012.
} 
de tutor, ou de supervisor. Aquele que se dispõe a educar alguém serviria, principalmente, como um interlocutor para aquele que ele pretende educar. Isto ocorre porque o educando precisa estabelecer um diálogo, a fim de poder se confrontar explicitamente com seus próprios preconceitos e, dessa forma, experimentar os limites de sua própria compreensão.

Assim, na visão de Gadamer, quando um diálogo verdadeiro se estabelece, o que ocorre é uma fusão de horizontes. O autor se mostrou interessado em elucidar essa fusão que condicionaria todo e qualquer diálogo e avaliou que ele não é uma mera estratégia de construção de consensos entre subjetividades, mas o modo pelo qual realizamos "uma espécie de expansão de nossa individualidade e um experimento da possível comunidade a que nos convida a razão" (GADAMER, 2004, p. 246). Por conta disso:

Poderíamos imaginar toda uma filosofia do diálogo, partindo dessas experiências: o ponto de vista intransferível do indivíduo, onde se espelha a totalidade do mundo, e a totalidade do mundo que se apresenta nos pontos de vista individuais de todos os outros como um e o mesmo. (...) a multiplicidade de espelhos do universo, representados pelos indivíduos, singulares, forma na sua totalidade um único universo. Isso se deixa configurar num universo do diálogo. (idem)

Antes de entrarmos em suas considerações acerca do diálogo propriamente dito, apresentaremos outros dois conceitos básicos da hermenêutica gadameriana: o de distância temporal e de história efeitual. Veremos como a partir desses conceitos Gadamer chega à articulação daquilo que ele nomeou como sendo o horizonte histórico da compreensão.

Dentro da filosofia de Gadamer, o conceito de horizonte produz um efeito imagético que é bastante ilustrativo a respeito do que sejam os limites e as possibilidades da compreensão humana. Com a elucidação do conceito de horizonte, chegamos finalmente à ideia sobre como é possível para cada indivíduo, por meio do diálogo, colocar seus preconceitos em jogo e expandir sua compreensão a partir de sua própria situação histórica.

Esta apresentação e todos os seus desdobramentos deverão trazer para o estudo elementos necessários para que compreendamos como se dá a transformação dos preconceitos de uma tradição, isto é, como se alteram as opiniões prévias que constituem um determinado horizonte histórico. Traremos também algumas objeções à concepção de diálogo de Gadamer, principalmente, as que foram feitas por Habermas e Paul Ricoeur. Por fim, ainda de acordo com as 
pistas de Gadamer, buscaremos em Platão, tomando como referência a Alegoria da Caverna, o modo como o autor descreveria - tendo como base o diálogo entre Sócrates e Gláucon - a construção dos preconceitos e seu papel na compreensão do homem acerca do mundo. Vale aqui explicitar que o encontro com Platão não se dá por acaso. No livro A ideia do bem entre Platão e Aristóteles, escrito por Gadamer, é possível perceber que existe uma tentativa de articular o conceito hermenêutico de compreensão com uma releitura do conceito de phronesis em Platão e Aristóteles.

A hermenêutica gadameriana se constitui a partir de uma determinada interpretação da noção aristotélica do "bem". Na filosofia prática de Aristóteles, uma questão central é que a ideia de bem não pode ser conhecida a priori. Como veremos na interpretação de Gadamer do conceito de phronesis, o que dá a medida da ação e permite que a consideremos justa ou não são, antes de tudo, as circunstâncias práticas das tomadas de decisão. Por isso, Gadamer defende que o bem enquanto uma ideia geral é uma antecipação à concretude de cada situação e por isso, a ideia de uma vida justa, orientada para o bem é necessariamente "vazia". Desse modo, nossa relação com a ideia de bem necessita ser uma experiência sempre crítica e interpretativa. (GADAMER, 2004, p. 320).

A partir dessa articulação, proposta por Gadamer, tomaremos a Alegoria da Caverna como um exemplo sobre como Platão concebeu o "falso saber", algo que em regra serviu como um termo análogo para o que se entende por "preconceito".

$\mathrm{Na}$ segunda parte, retornamos ao contexto da educação brasileira e apresentamos mais detalhadamente como uma educação hermenêutica pode se configurar dentro de uma terceira via diante da polarização existente entre as duas tendências que esboçamos anteriormente: uma que prega o enrijecimento disciplinar das instituições de ensino e outra que acredita que o único caminho possível, em última análise, seja o da disrupção. Em seguida, apresentaremos a crítica de Gadamer ao modo como se tem pensado a organização política e econômica em escalas mundiais e como isso se reflete no modo como lidamos com as diferenças. Por fim, chegamos ao questionamento sobre a possibilidade de uma educação hermenêutica, atenta ao caráter processual da construção da subjetividade e às potencialidades que a formação estética traz para o campo da formação ética dos indivíduos. 
Vale aqui, já de início, fazer o alerta de que pensar a experiência da compreensão humana a partir de Gadamer e sob uma perspectiva hermenêutica é muito mais um exercício de ver que, muitas vezes, “o que está em questão não é o que nós fazemos, o que nós deveríamos fazer, mas o que, ultrapassando nosso querer e fazer, nos sobrevém, ou nos acontece", como o próprio autor nos esclarece (GADAMER, 1997, p.14). Somente tendo compreendido esse aspecto fundamental, estaremos a caminho de uma elucidação da experiência de nossa formação em toda a sua complexidade.

Antes de caminharmos em direção às questões conceituais que balizam nosso estudo, consideramos pertinente apresentarmos de um modo mais detalhado tanto o autor quanto a obra que fundamentará nossos estudos. Hans-Georg Gadamer e sua obra mais valiosa e conhecida, Verdade e Método I, surgiram em um horizonte histórico que não pode deixar de ser mencionado: a Alemanha do século XX, do pós-Segunda Guerra. Embora as referências teóricas de Gadamer remontem em grande medida aos clássicos gregos, o contexto em que emergem o autor e sua obra é um contexto de grandes transformações históricas, impulsionadas também pelo avanço tecnológico, uma circunstância que influenciará de modo decisivo sua crítica ao enrijecimento metodológico das ciências humanas, que de um modo equivocado buscaria assegurar sua legitimidade adotando os padrões das ciências da natureza.

\section{1.}

\section{Gadamer e o contexto de produção de sua obra ${ }^{5}$}

Hans-Georg Gadamer viveu entre os anos de 1900 e 2002 e dedicou quase que a totalidade de seu mais de um século de existência à filosofia. Nascido em 11 de fevereiro de 1900 na cidade de Marburg, localizada no estado de Hessen, na Alemanha central, Gadamer, vivenciou nos seus primeiros anos de vida toda a empolgação gerada no início do século em razão dos novos avanços científicos e tecnológicos. Nas ruas das cidades, os primeiros carros se misturavam com as

\footnotetext{
${ }^{5}$ Nesse capítulo usaremos como referências básicas para falar sobre o desenvolvimento intelectual de Gadamer as seguintes obras: DI CESARE, Donatella. Gadamer: a Philosophical portrait. English translation by Insiana University Press, Bollmington, Indiana, 2013; GADAMER, HansGeorg Hermenêutica em retrospectiva: Heidegger em retrospectiva. 1. ed. Tradução de Marco Antônio Casanova. Petrópolis: Vozes, 2007; SCHMIDT, Lawrence K. Hermenêutica; tradução de Fábio Ribeiro, 3.ed. - Petrópolis, RJ: Vozes, 2014, além de fontes complementares que nos auxiliarão com datas e outras informações.
} 
carruagens puxadas por cavalos. Lanternas de gás estavam sendo substituídas por luzes elétricas, o telefone popularizava-se, os cinemas abriam suas portas e o famoso Titanic estava sendo construído. A fé otimista na tecnologia fazia-se presente por toda parte.

Quando Gadamer tinha dois anos de idade, seu pai, Johannes Gadamer, que era um conhecido professor de química farmacêutica, foi convidado para a cadeira de professor titular na Universidade de Breslau, Silésia (atual Polônia). Com isso, toda a família mudou-se para esta cidade onde Gadamer passou a infância e a adolescência. Infelizmente, muito cedo, no ano de 1904, a mãe de Gadamer, Emma Caroline Johanna Gewiese, adoece de diabetes e morre. Apesar de sua pouca idade na época, apenas quatro anos, Gadamer consegue guardar de sua mãe uma viva memória sobre seu gosto por música, arte e seu amor pela literatura.

O contexto da época era de um inaudito progresso econômico e tecnológico e, nos anos que se seguiram, embora fosse uma cidade provinciana e bastante tranquila, mesmo Breslau viu nos primeiros anos desse novo século sua população aumentar exponencialmente, o que acentuou os efeitos econômicos e políticos trazidos posteriormente pelo final da Primeira Guerra. No ano de 1918, Gadamer matricula-se na Universidade de Breslau e a frequenta por dois semestres. No ano seguinte, no entanto, transfere-se para Marburg. Seu pai havia sido convidado a ocupar uma cadeira e dois anos mais tarde chega ao cargo de reitor dessa Universidade. Dessa forma, Gadamer o acompanhou de volta a sua cidade natal.

Seu primeiro ano na vida universitária, ainda em Breslau, havia sido revelador para Gadamer. No primeiro semestre, Gadamer frequentou alguns cursos na área de humanidades: alemão, arte, história, psicologia e estudos asiáticos. Já no segundo semestre, começou a seguir os cursos de alguns neokantianos, dentre eles, Richard Hönigswald (1875-1947). Foi Hönigswald quem insistiu para que ele seguisse no estudo de filosofia admitindo-o para um seminário sobre filosofia da linguagem, do qual só faziam parte alunos mais avançados. Apesar da sua pouca experiência, Gadamer se destacou, o que o deixou confiante a seguir o caminho da filosofia, mesmo sabendo que esse seu interesse não agradava a seu pai:

Meu pai era um pesquisador das ciências da natureza e pouco amigo do saber livresco, embora conhecesse Horácio muito bem. Por isso, durante minha infância, de muitas maneiras, tentou despertar meu interesse pelas ciências naturais, ficando 
muito decepcionado com meu fracasso. Isso porque soube desde o começo de meus estudos universitários que eu simpatizava com os "professores tagarelas". Nisso, ele não me impediu, mas durante toda a sua vida permaneceu insatisfeito com esse fato. (GRONDIN (org), 2012, p.23)

Em Marburg, Gadamer dá continuidade a seus estudos ao lado de renomados professores. Por uma feliz coincidência, haviam se mudado para lá pesquisadores que eram considerados pertencentes à elite intelectual alemã da época. Dentre eles estavam Ernst Robert Curtius (1886-1956), especialista em estudos do Romantismo, Rudolf Bultmann (1884-1976) célebre teólogo protestante, Richard Hamann (1879-1961) pesquisador de história da arte, além de Paul Natorp (1854-1924) e Nicolai Hartmann (1882-1950), figuras emblemáticas do neokantismo. Gadamer esteve em contato direto com esses grandes nomes do círculo acadêmico alemão durante os vinte anos em que permaneceu, entre idas e vindas, na Universidade de Marburg.

Ao chegar a Marburg, Gadamer se aproximou especialmente de Nicolai Hartmann e de Paul Natorp. Ambos guiaram Gadamer nas etapas iniciais, sobretudo Hartmann, com quem Gadamer manteve uma relação bastante próxima. A Universidade de Marburg se notabilizou, por muito tempo, por abrigar uma influente escola de especialistas na filosofia de Kant, a qual tinha na figura de Hermann Cohen (1842-1918) seu principal expoente. Com a mudança de Cohen para Berlim, o jovem Hartmann passou a ser visto como o último grande representante do neokantianismo de Marburg. Hartmann, contudo, se distanciava cada vez mais dessa corrente em favor do "realismo crítico". Apesar da pouca idade, Hartmann foi para Gadamer uma grande referência e foi por sua influência que Gadamer buscou em Natorp a orientação para escrever seu trabalho de final de curso. Após a redação do trabalho, Hartmann e Natorp avaliaram a dissertação e, apesar de terem feito críticas diametralmente opostas, ambos concordaram em dar a nota máxima para Gadamer pelo trabalho.

Gadamer, posteriormente, recebe aos 22 anos o título de doutor em filosofia com o trabalho intitulado A Essência do Prazer de acordo com os Diálogos de Platão (Das Wesen der Lust nach den Platonischen Dialogen). Essa preocupação com o pensamento platônico se fez presente em toda sua obra. Como bem observa Rohden (2017, p.45), mesmo quando não o faz explicitamente, Gadamer parece estar constantemente discutindo com Platão. Para o autor, os ideais dos textos platônicos e a figura de Sócrates nunca se distanciam das preocupações de 
Gadamer. Contudo, Gadamer é certamente mais conhecido por sua admitida filiação ao pensamento heideggeriano. Sua obra é construída na esteira da hermenêutica heideggeriana, no entanto, apesar da proximidade que existiu entre Gadamer e Heidegger, Gadamer não se rende ao estilo grandiloquente e muitas vezes hermético de Heidegger. Seus escritos dialogam com o leitor de uma maneira mais próxima, ao mesmo tempo em que preservam a densidade e a complexidade daquilo que é dito. Para alguns comentadores, como Di Cesare (2007), Gadamer permaneceu fiel a sua inspiração socrática no diálogo, principalmente por uma questão de coerência, uma vez que ele acreditava, de fato, na possibilidade da promoção de encontros por meio de um diálogo verdadeiro. Dessa maneira, para filosofar, "Gadamer precisava ir à Ágora, deixar-se surpreender pelos encontros com os outros e, ao mesmo tempo, surpreender os outros nesses encontros." (DI CESARE, 2007, p. 2).

Infelizmente, logo após sua formatura, em agosto de 1922, Gadamer contraiu poliomielite, uma doença viral grave, para a qual ainda não havia vacina. Gadamer superou lentamente a doença, ficando apenas com leves sequelas motoras ao longo de toda a sua vida. No período mais severo de manifestação da doença, Gadamer precisou manter-se em repouso absoluto, algo que durou longos meses. Durante esse período, dedicou-se à leitura de algumas obras, como as Investigações Lógicas de Edmund Husserl (1859-1938). No entanto, outra leitura feita nesse mesmo período foi mais decisiva em sua vida. Seu professor orientador, Paul Natorp, emprestou-lhe um manuscrito sobre Aristóteles cuja autoria era do jovem assistente de Husserl em Freiburg, Martin Heidegger (18891976).

$\mathrm{O}$ efetivo encontro entre Gadamer e Martin Heidegger se deu no ano seguinte, em 1923, na cidade de Freiburg. Antes mesmo de sua doença, Gadamer já havia ouvido rumores a respeito do "jovem filósofo revolucionário" (GADAMER, 2007, p.10), assistente de Husserl, entre seus colegas e professores em Marburg. Os relatos que ouvia dos estudantes que haviam estado com Heidegger eram intrigantes, mas foi mesmo a leitura do manuscrito sobre Aristóteles, entregue a ele por Natorp, que "o tocou como um choque elétrico" (idem) e o fez querer ir ao encontro do filósofo. O trabalho, intitulado Indicação da Situação Hermenêutica era a introdução de um livro sobre Aristóteles e 
apresentava uma linguagem completamente nova, expressiva e intensa. Com esse manuscrito, Heidegger pleiteava uma possível vaga de professor em Marburg.

Chegando à Universidade de Freiburg, Gadamer teve o seu decisivo encontro com Heidegger. Encontro este que o próprio Gadamer descreve de maneira bastante peculiar:

O meu primeiro encontro com Heidegger em Freiburg transcorreu de maneira extremamente estranha. Dirigi-me à sala na qual ele tinha seus horários de atendimento e percebi que havia vozes na sala. Assim, retirei-me e fiquei esperando no corredor. Então, a porta se abriu e uma pessoa foi levada para fora por um homem muito pequeno de olhos pretos. Eu disse para mim mesmo: 'Que pena, ainda tem alguém lá dentro'. E continuei esperando. Somente depois de um longo tempo procurei escutar de novo junto à porta, não ouvi mais vozes, bati e entrei. O pequeno homem moreno que não correspondia às minhas expectativas era Martin Heidegger. Quando comecei a conversar com ele e vi os seus olhos, compreendi sem qualquer comentário que fenomenologia tinha alguma coisa em comum com a visão. Nesses olhos não havia apenas uma perspicácia penetrante, mas antes de tudo também fantasia e força intuitiva. (GADAMER, 2007, p.11)

Nos meses que se seguiram a esse encontro, Gadamer esteve presente nos cursos dados por Heidegger naquele semestre e teve o privilégio de acompanhar a preleção de uma hora semanal intitulada Ontologia na qual, segundo Gadamer (idem), Heidegger apresentou pela primeira vez a sua análise do mundo circundante que veio a se tornar conhecida mais tarde na célebre obra Ser $e$ Tempo. Curiosamente, Heidegger havia preparado um curso de lógica para aquele semestre de verão de 1923, mas ao saber que um colega daria o mesmo curso, decidiu mudar o tópico e anunciou o novo título. Tempos depois, o título Ontologia foi mudado para A hermenêutica da Facticidade. Assim, como observa Di Cesare (2007, p 20), o primeiro encontro entre os dois filósofos aconteceu sob a bandeira da hermenêutica. Gadamer descreve que o que era dito nos cursos, para ele, que havia sido educado na linguagem da "lógica universal" da escola de Marburg, chegava como "tons completamente novos". Esses tons, contudo, mesmo dentro da escola fenomenológica de Freiburg, eram os tons próprios de um novo pensador: Martin Heidegger. Somente tempos depois, Gadamer veio a entender que na fala de Heidegger "ressoavam efeitos indiretos de Nietzsche por um lado, e, por outro lado, do pragmatismo americano" (GADAMER, 2007, 
p.12), mas sobretudo de Emil Lask $(1875-1915)^{6}$, cujas obras passaram a ser frequentemente citadas por Heidegger.

Naquele mesmo semestre, Heidegger ofereceu quatro seminários, um dos quais tratava do Livro VI da Ética a Nicômaco. O conceito de phrónesis, discutido naquelas páginas de Aristóteles ganhou para Gadamer novos contornos a partir da leitura de Heidegger e o influenciou definitivamente em suas obras. Esses primeiros encontros promoveram também em Gadamer um encontro com outras inquietações que ele carregava:

Aquilo de que tinha me ressentido em minha formação neokantiana em Marburgo e que também não consegui preencher por meio de estudos ocasionais, por exemplo, das obras de Dilthey, de Max Weber ou de Ernst Troeltsch, veio ao meu encontro corporeamente com o jovem Heidegger. Não se tratava mais de ciências e de sua justificação epistemológica, nem tampouco da extensão magistral das análises apriorísticas ao mundo da vida que Husserl tinha promovido. O que estava essencialmente em questão era a historicidade do ser-aí humano, a solução do problema do relativismo histórico - melhor, o questionamento crítico do modo de colocação do problema segundo o qual o relativismo histórico se mostrava como insolúvel. (GADAMER, 2007, p.16)

Ainda no ano de 1923, Heidegger tem seu manuscrito aprovado e é convidado a lecionar em Marburg. Gadamer o acompanhou, juntamente com um grupo de outros quinze estudantes. Antes de partirem, Heidegger convidou Gadamer e sua esposa para passarem, no período de férias, quatro semanas em sua cabana em Todtnauberg. Heidegger desejava dedicar essas quatro semanas à leitura da Metafísica de Aristóteles e, seguindo seu professor, Gadamer aprendeu não só a ler Aristóteles "fenomenologicamente", como também aprendeu a abordar questões filosóficas sobre seu próprio tempo. (DI CESARE, 2007, p 7).

Certamente, Heidegger, que nunca havia saído de Baden-Württemberg, aproveitou o momento para inteirar-se a respeito do cenário que encontraria em Marburg. Segundo Gadamer, "sobre a cena de Marburg, pairava o espírito déspotico de Hermann Cohen, mesmo depois de sua morte - e em reação a ela" (GADAMER, 2007, p.14). O resgate da filosofia aristotélica dividia opiniões e o neokantianismo era o que dava a tônica dos debates em Marburg.

\footnotetext{
${ }^{6}$ Emil Lask, que também influenciou pensadores como Georg Lukács, formou-se em Freiburg e depois foi nomeado professor em Heidelberg em 1905. Em 1914, no início da Primeira Guerra, alistou-se como voluntário e acabou sendo enviado para o campo de batalha, de onde não voltou. Apesar de sua breve trajetória, foi um dos jovens pensadores mais influentes do neokantismo.
} 
Heidegger foi muito bem recebido em Marburg pelos estudantes, que rapidamente encheram seus seminários. Alguns de seus colegas, no entanto, de início não o acolheram tão bem, sobretudo Hartmann, com quem Heidegger teve alguns embates. Nesse contexto de disputa, o próprio Gadamer se viu rechaçado por Heidegger, que o via como fruto de uma aristocracia acadêmica e ainda, em grande medida, seguidor de Hartmann e Natorp - de quem Heidegger reconheceria apenas a influência neokantiana.

Apesar da falta de confiança expressa por seu mestre, Gadamer permanece próximo a Heidegger. Após ser aprovado em 1927 no exame do estado em Filologia Clássica, escreve sua Habilitationsschrift (trabalho de qualificação para o ensino) sob sua orientação. Nesse mesmo período, o pai de Gadamer adoece e é internado na clínica da Universidade de Marburg. Ele morre em abril de 1928. Mesmo diante dessa difícil situação, Gadamer consegue concentra-se mais uma vez em Platão e em obter sua certificação em fevereiro de 1929. Seu escrito se intitulava Interpretações Fenomenológicas do Filebo de Platão e foi publicado em 1931 como A Ética Dialética de Platão. O trabalho foi concebido como um estudo preliminar da Ética a Nicômaco e recebeu uma avaliação bastante positiva tanto de Heidegger quanto de Paul Friedländer - de quem Gadamer se tornava cada vez mais próximo.

Anos depois, em notas autobiográficas, Gadamer reflete sobre seus sentimentos com relação a si mesmo diante de tais circunstâncias: "Estes foram anos de profunda dúvida sobre meus dons intelectuais, contudo, foram também os anos em que eu finalmente comecei a trabalhar seriamente. Eu me tornei um filologista clássico sob a orientação do amigável Paul Friedländer.” (GADAMER apud DI CESARE, p.9). Gadamer diz também que, diante da enormidade de Heidegger e de seu pensamento, o que lhe caberia fazer era buscar seu próprio terreno, onde pudesse contruir seu pensamento com independência, caso contrário, ele "poderia ser simplesmente esmagado" (idem) pelo domínio do pensamento heideggeriano.

Nesse período, Gadamer tornou-se parte da Graeca de Rudolf Karl Bultmann - teólogo luterano que ficou conhecido por sua abordagem hermenêutica do Novo Testamento e por ser defensor de uma teologia dialética. Dentro da academia, a Graeca é um círculo de docentes e estudantes que se reunem para ler e interpretar textos de literatura clássica juntos. Gadamer reuniu- 
se com a Graeca de Bultmann por quinze anos consecutivos e nele teve uma profunda experiência formativa. Ao mesmo tempo, também reunia-se com colegas mais próximos para ler tanto os grandes romances de Balzac, Tolstoi, Dostoiévski, Gogol e Gontcharov, quanto autores modernos como Joseph Conrad, Knut Hamsun e Andre Gide.

Gadamer também fazia parte de outra Graeca, a de Paul Friedländer. Em sua Graeca, Friedländer dedicava-se principalmente aos estudos de Platão, Aristóteles e de poetas gregos como Píndaro. Gadamer foi um dedicado colaborador de Friedländer e, segundo o próprio Gadamer, foi durante esses estudos que ele passou a ver que o diálogo em Platão não era apenas um recurso estilístico textual. Ele seria em si o motivo principal da filosofia de Platão, o que mais tarde aparece no pensamento gadameriano, sobretudo, na ideia dos diálogos platônicos como construtos figurativos (Gebilde) ou portraits ${ }^{7}$.

A essa altura, Heidegger já havia se tornado o autor de Ser e Tempo (1927) e estava prestes a voltar para Freiburg para suceder Husserl, que havia se aposentado. Heidegger, logo depois, no ano de 1933, em plena ascensão de Hitler ao poder, assume o cargo de reitor da Universidade de Freiburg, mas, no ano seguinte, renuncia por causa de divergências políticas com o regime. Gadamer, por sua vez, continuou atuando como Privatdozent, oferecendo cursos regulares na Universidade de Marburg sobre a ética aristotélica e a República de Platão. Nesse período, o regime nazista estava cada vez mais fortalecido e a pressão pelo controle das universidades aumentava. Enquanto Heidegger acaba optando por uma polêmica filiação ao Partido Nacional-Socialista, Gadamer opta pela discrição política nesse período. Ele se concentrou no trabalho cotidiano de professor universitário e em aprofundar seus estudos sobre os autores clássicos ao que tudo indica, afastando-se do conturbado ambiente político, inclusive, sem fazer publicações acadêmicas de maior relevância entre os anos de 1933 e 1945. Anos mais tarde, Gadamer refletiu sobre a ascensão de Hitler ao poder:

Foi um terrível despertar, e nós não podemos nos absolver por não termos atuado adequadamente como cidadãos. Nós subestimamos Hitler e sua gente, e reconhecidamente cometemos o mesmo erro que a imprensa liberal ao fazer isso. Nenhum de nós havia lido Mein Kampf. (GADAMER, apud DI CESARE, p.11)

\footnotetext{
${ }^{7}$ Sobre esse assunto, $C f$. GRONDIN, Jean (org), Platão como portatista. In: GRONDIN, Jean (org.) O Pensamento de Gadamer. Tradução de Enio Paulo Giachini. - São Paulo: Paulus, 2012.
} 
Existe a crença de que dentro da Universidade, na época, havia uma falsa estimativa sobre a realidade política da época. Os acadêmicos estariam convencidos de que o nacional-socialismo seria algo tolo demais para durar por muito tempo. Os meios de comunicação estavam sob controle do Estado e também havia uma forte propaganda do Partido Nazista que misturava táticas de terror a um forte apelo ao sentimento nacionalista, como ressalta Di Cesare. Nesse contexto, até mesmo o antissemitismo para muitos parecia algo primitivo demais para ser verdadeiro. Alguns eventos, no início do regime, eram interpretados como ocorrências isoladas. Contudo, gradativamente eles revelaram seu real contorno: tornaram-se uma perseguição sistemática aos judeus, comunistas, oponentes políticos e todos que eram considerados como inimigos. Dentro da Universidade de Marburg, o resultado foi desolador, como nos conta Di Cesare:

As Leis de Nuremberg finalmente não deixaram espaços para ilusões. Todos os Dozenten da "raça" judia foram forçados a deixar o ensino, e a Universidade de Marburg foi esvaziada por esse decreto. Enquanto alguns, como Erich Frank (1883 - 1949), conseguiram se aposentar, mesmo após a Kristallnacht (Noite dos Cristais) em 1938, e continuar a viver na Alemanha, a maioria deixou o país dentre os primeiros a sair estava Löwith. Ele foi seguido por Strauss, Friedländer, Spitzer, Klein, Auerbach, Kroner e Jacobstahl, para citar apenas alguns nomes. "Sentimos vergonha de permanecer", Gadamer comentou mais tarde. (DI CESARE, 2013, p.12)

Paul Friedländer, com quem Gadamer havia trabalhado de maneira muito próxima, foi forçado a sair da Universidade em 1938 e chegou a ser detido em um campo de concentração. Após sua libertação, mudou-se para os Estados Unidos, onde lecionou primeiro na Universidade Johns Hopkins, em 1939 e, posteriormente, na University of California, Los Angeles (UCLA), entre 1940 e 1945. Na mesma época, Gadamer se torna professor titular e catedrático em filosofia na Univesidade de Leipzig (1939), depois de vários cargos temporários em Kiel e Marburg.

Ao refletir sobre este período, posteriormente, Gadamer chega à conclusão de que a desordem promovida pela Primeira Guerra Mundial e o cenário que se instaurou posteriormente na Alemanha, com o nazismo, foram decisivos para uma transformação cultural.

Mesmo no campo da filosofia, já não era viável para nós, os jovens, prosseguirmos simplesmente o que havia sido criado pela geração anterior. $\mathrm{O}$ neokantismo que 
gozava de uma verdadeira vigência mundial, embora contestada, havia desmoronado nas frentes de batalha junto com a orgulhosa consciência cultural da época liberal, com sua fé no progresso da ciência. Nós, na época jovens, buscávamos uma nova orientação em um mundo desorientado. Nessa situação, vimo-nos reduzidos praticamente ao cenário alemão, onde a amargura e o afã de renovação, a pobreza, a desesperança e a vontade inquebrantável de viver da juventude combatiam entre si. Sua expressão cultural foi inequívoca. O expressionismo na vida e na arte passou a ser a força dominante. (GADAMER, 2002, p. 545-546)

Dentro das universidades houve todo tipo de reação frente ao nazismo. Havia os que apoiavam abertamente o regime e se assumiam como antissemitas, como, por exemplo, Gottlob Frege, pai da filosofia analítica (DI CESARE, 2013, p.13). Mas, havia também os que chegaram a se filiar ao partido e que, posteriormente, buscaram se desembaraçar com relação ao apoio ao regime, como fez Heidegger, enquanto outros adotaram uma posição de afastamento do debate político, como foi o caso de Gadamer.

Mas, o mais importante a se destacar aqui é que Gadamer, apesar das proibições, manteve-se em contato com seus colegas judeus, chegando a abrigar seu amigo Klein em sua casa por quase dois anos, de 1933 a 1934. Ele também ofereceu apoio a Erich Frank até que este saísse de Marburg em 1939 e manteve troca de correspondência com Löwith durante o período nazista.

A relação entre Gadamer e Heidegger ficou, entretanto, um pouco distante entre os anos de 1933 e 1936. Heidegger, após ter retornado a Freiburg, enviou uma pasta com vários escritos a Gadamer e a assinou com uma "saudação alemã". Gadamer não a respondeu e o contato entre os dois ficou interrompido até o final do semestre de verão de 1935, quando Gadamer tem notícias de que Heidegger ofereceria uma série de palestras próximo a Frankfurt sobre A Origem da Obra de Arte. Gadamer que havia escolhido naquele semestre falar em um de seus cursos sobre o tema Arte e História -Introdução às Humanidades, foi mais uma vez ao encontro de Heidegger sem hesitar. Junto com ele também foram Frank e Gerhard Krüger.

Para além das questões políticas, Gadamer via em Heidegger uma potência de pensamento, como ele mesmo reconhecia, alguém capaz de lhe ensinar "coisas decisivas". Gadamer estava ligado a Heidegger por uma congruência no pensamento. As questões que mobilizavam Gadamer iam ao encontro do pensamento heideggeriano: 
Se também no que diz respeito às coisas decisivas aprendi a maior parte delas com Heidegger, então o instante em que ouvi falar pela primeira vez em Frankfurt (1935) sobre a "Origem da obra de arte" foi mais uma confirmação daquilo que eu mesmo buscava há muito na filosofia. (GADAMER, 2007, p.118)

Evidentemente, não é uma tarefa fácil fazer uma releitura dos acontecimentos daquela época e julgar o envolvimento de alguns intelectuais alemães com o nazismo. Contudo, nesse contexto há pelo menos dois fatos que chamam a atenção: a recusa de Gadamer em se deixar influenciar pela adesão de Heidegger, por quem nutria uma forte admiração e respeito, e a renúncia precoce de Heidegger ao cargo de reitor - um ano após seu ingresso. Há de se considerar também que Heidegger restabelece o contato com seus alunos judeus, logo após seu desligamento do partido. Como relata Di Cesare:

\begin{abstract}
A atitude de Gadamer em relação ao seu professor e às suas escolhas políticas foi semelhante às respostas dos outros alunos de Heidegger, tanto antes quanto, sobretudo, após a guerra. Tirando algumas exceções - Günther Anders (1902-1992) e Herbert Marcuse (1898-1979) que devem ser mencionadas - nenhum foi intransigente e, após o rompimento em 1933, todos reestabeleceram o contato. Embora eles não tenham seguido seu caminho, seus alunos - até mesmo os judeus alemães - eram incapazes de reconhecer sua adesão ao nacional-socialismo e a seriedade de seu envolvimento. O próprio Löwith nunca rompeu a correspondência com Heidegger. Hannah Arendt restaurou sua amizade com seu ex-professor em seu retorno à Alemanha em 1950 e, em um ensaio publicado em 1969 para comemorar o Octogésimo aniversário de Heidegger, ela escreveu em uma nota de rodapé sobre seu envolvimento com o Nacional-Socialismo como se tivesse sido uma "escapada". (DI CESARE, 2013, p.15)
\end{abstract}

Em 1939, Gadamer finalmente, após quase dez anos de espera, recebe uma cadeira na Universidade de Leipzig. No mesmo ano, em $1^{\circ}$ de setembro, tem início a Segunda Guerra Mundial com a invasão da Alemanha à Polônia. Leipzig estava, de certo modo, distante do patrulhamento ideológico nazista. Desse modo, mesmo estando proibido o estudo de autores de origem semita, Gadamer consegue ministrar aulas, inclusive sobre Husserl, sem ser incomodado.

Os anos da Guerra levaram a Universidade de Leipzig a sua quase total destruição. Em dezembro de 1943, mais da metade dos edifícios foram destruídos. Os encontros entre professores e estudantes, contudo, não cessaram. As aulas continuaram a serem oferecidas nos alojamentos e nos abrigos antiaéreos como relata Gadamer:

Os últimos anos da guerra foram muito perigosos, como é natural. Mas os numerosos bombardeios a que tínhamos que sobreviver e que reduziram a escombros a cidade de Leipzig e os meios de trabalho da universidade tiveram 
também seu lado bom. As situações extremas fizeram com que o terror do partido mudasse de direção. As aulas na universidade, passando de um local de emergência para outro, continuaram até pouco antes de finalizar a guerra. Quando os americanos ocuparam Leipzig, eu estava estudando os volumes 2 e 3, recémpublicados, da Paideia de Werner Jaeger. Isso também, algo raro de acontecer, obra de um "emigrante", escrita em alemão e publicada em editorial alemão, aparecendo nos piores anos da guerra. Guerra total? (GADAMER, 2002, p. 560)

Em abril de 1945, as forças americanas de ocupação entraram em Leipzig e dois meses depois o controle político e administrativo da cidade foi entregue aos soviéticos. No ano seguinte, foi necessário escolher um novo reitor para a Universidade e, por nunca ter sido membro do Partido Nazista, Gadamer foi o escolhido. A Universidade reabre em fevereiro de 1946 já sob a gestão de Gadamer. Para Kahlmeyer-Mertens, embora Gadamer estivesse longe de ser um bom negociante político, "sua disposição para o diálogo com a autoridade soviética, que ocupava aquela região durante o processo de redemocratização da Alemanha, foi crucial para conservar a autonomia científica (...)" (KEHLMEYER-MERTENS, 2017, p. 67). Desse modo, enquanto muitos acadêmicos precisaram se justificar perante a comissão de desnazificação que foi aberta na Alemanha no pós-guerra, Gadamer pode seguir sua vida acadêmica sem problemas.

Havia, contudo, algo que o impedia de escrever livremente, algo que ele mesmo só conseguiria se dar conta anos mais tarde, diz Gadamer: “(...) durante muito tempo escrever representou para mim uma verdadeira tortura. Sempre tinha a desagradável impressão de que Heidegger estava me espreitando por cima dos ombros" (GADAMER, 2002, p.560).

Gadamer permaneceu por dois anos na reitoria. Em 1947, aceitou um convite da Universidade de Frankfurt e se mudou para lá. Sua passagem por Frankfurt foi breve. Gadamer não se sentiu ambientado com o pensamento frankfurtiano. Em 1949, muda-se mais uma vez, desta vez para Heidelberg, onde substituiu Karl Jaspers, que se transferiu para Basel (Suíça). Gadamer havia se divorciado de sua primeira esposa durante a guerra, mas, já em Heidelberg, volta a se casar em 1950.

As atividades universitárias se intensificam na medida em que a ordem no pós-guerra volta a se estabelecer. Nesse período, Gadamer traduz, edita e comenta o livro XII da Metafísica de Aristóteles e também publica $O$ esboço de uma história geral da filosofia de Dilthey. Em parceria com Helmut Kuhn, cria um 
periódico intitulado Philosophische Rundschau, que chega a ficar bastante importante na Alemanha na época. Além disso, ainda se torna presidente da Sociedade Alemã de Filosofia e membro da Academia de Ciências de Heidelberg. Nesse período, Gadamer dá início também à escrita de sua mais grandiosa obra.

Tendo vivido vinte anos em Marburg, como estudante e docente, passaria agora mais de um quarto de século trabalhando em Heidelberg. E, apesar das inúmeras tarefas de reconstrução que incumbiam a todos, pude evadir-me mais uma vez da política em geral e da política universitária em particular para concentrar-me em meus planos de trabalho, que tiveram uma primeira conclusão no ano de $1960 \mathrm{com}$ a obra Verdade e Método I. (GADAMER, 2002, p.561)

Foram quase dez anos dedicados à escrita deste livro, no qual Gadamer reúne em uma obra de quase quinhentas páginas - tendo como referência o livro original em alemão - seus diversos ensaios escritos ao longo de sua vida até então. Nesses ensaios, ele estabelece um diálogo não só com Heidegger, mas com diversos representantes de diferentes correntes de pensamento em diálogo com a sua hermenêutica filosófica.

A história que se desenrola em torno da escolha do título do livro demonstra o quanto ainda era pouco clara a nova conotação que a palavra "hermenêutica" começava a ganhar. Embora, como sinaliza Di Cesare (2013, p.24), a palavra já tivesse emergido com seu novo sentido no livro de Bultmann em 1950, $O$ Problema da Hermenêutica, havia também uma questão editorial na escolha do título: a palavra "hermenêutica" soava ainda algo obscuro demais, como relata o próprio autor.

A questão a respeito do título do livro tornou-se árdua. Meus colegas compatriotas e estrangeiros esperavam a obra como uma hermenêutica filosófica. Mas, quando propus esse título o editor me perguntou: $\mathrm{E}$ isso o que é? Na realidade, foi melhor relegar a expressão ainda estranha para o subtítulo. (GADAMER, 2002, 562)

Como observa Jean Grondin (apud KAHLMEYER-MERTENS, 2017, p.46), um fato curioso sobre o aparecimento de Verdade e Método I é que, apesar de Gadamer já ter 60 anos na ocasião do lançamento da obra, esta é considerada um escrito de juventude do autor. Gadamer não havia publicado, até então, nenhuma obra de grande fôlego na qual expusesse um pensamento próprio. Verdade e Método I trouxe a público o pensamento de Gadamer e o tornou um autor de referência. Consequentemente, sua obra recebeu a apreciação crítica de muitos pensadores de sua época, que publicaram artigos e ensaios sobre o 
trabalho. Impulsionado por essas críticas, Gadamer lança então diversos ensaios em resposta. Muitos deles foram reunidos quase duas décadas depois em Verdade e Método II.

\section{2.}

\section{Verdade e Método I: uma breve introdução à obra}

A gênese de minha filosofia hermenêutica, no fundo, não é nada mais que a tentativa de explicar teoricamente o estilo de meus estudos e de meu ensino. A práxis veio primeiro. Sempre procurei, quase com ânsia, não me perder em construções teóricas que não proviessem totalmente da experiência (GADAMER, 2002, p.561)

Para entrar na apresentação da obra propriamente dita, é importante ressaltar que, como vimos, Gadamer escreve em um contexto histórico bastante fecundo. A desordem provocada pela guerra reavivou no campo do pensamento questões profundas com relação ao ser humano. Na visão do autor havia, contudo, o prenúncio do "protagonismo de uma geração dominada em parte pelas expectativas tecnológicas e em parte pela afeição à crítica da ideologia." (GADAMER, 2002, p.562).

Se, por um lado, o avanço tecnológico era irreversível, por outro, havia quem o visse com ressalvas. Já na década de 1930, Walter Benjamin condenava a regência tecnocrática das questões sociais e afirmava que a sociedade deve "excluir as ideias técnicas de qualquer direito de coparticipação na ordem social" (BENJAMIN, 2008, p.61). Para Benjamin, o descompasso entre o desenvolvimento técnico e o esclarecimento de questões morais fazia com que as dimensões técnica e espiritual se aproximassem de forma perigosa. Ainda segundo o autor, embora a técnica não fosse suficientemente forte para dominar as forças elementares da sociedade, o homem ainda não teria encontrado meios adequados para usá-la em seu proveito.

Gadamer também dedica grande parte de seu trabalho para chamar a atenção ao modo como a ciência moderna segue uma "marcha vitoriosa" de domínio por toda a parte. Para ele, essa marcha, iniciada no século XIX, passou a ser um fator social predominante, a partir do momento em que ela se torna a base da nossa civilização e se apodera de todos os âmbitos da vida social: 
A investigação científica do mercado, a condução científica da guerra, a ciência da política externa, o controle científico da natalidade, a ciência para a condução da vida humana etc. conferem ao especialista em economia e sociedade um lugar central. (GADAMER, 2002, p.183)

Frente a esse vertiginoso predomínio do método da ciência moderna, Gadamer se mostra disposto a voltar a pôr em discussão a questão da verdade. Sobretudo a experiência da verdade que ultrapassa o campo de controle metodológico da ciência moderna. Ele, então, indaga em que se assenta a legitimação dessa experiência. Dessa maneira, Gadamer dá início já na primeira parte de Verdade e Metodo I à discussão acerca da experiência de verdade manifestada na obra de arte.

Sob o título A Liberação da Questão da Verdade desde a Experiência da Arte, a primeira parte das três nas quais se divide a obra, Gadamer percorre todo o caminho das interpretações concorrentes acerca da teoria estética, do juízo, do gosto, da beleza, da vivência, da formação, da abstração até chegar à discussão sobre a ontologia da obra de arte e o seu significado para a hermenêutica, após o que finalmente apresenta seu conceito central de jogo.

Em seu prefácio à segunda edição, o autor nos diz: "não foi um mero artifício de composição, se eu coloquei o meu ponto de partida na experiência da arte, para garantir a amplidão correta ao fenômeno do compreender." (GADAMER, 1997, p.18). A busca pela questão da verdade na obra de arte, na filosofia de Gadamer, não se dará nem pelo viés de uma consciência estética do sujeito (algo que tomaria a subjetividade como referência), nem tampouco pelo viés da obra de arte como objeto. Para Gadamer, a questão se dá nos termos de uma experiência, algo que acontece entre o sujeito e a obra. Foi nesse sentido que Gadamer considerou o jogo como o próprio modo de ser da obra de arte:

A obra de arte tem, antes, o seu verdadeiro ser em se tornar uma experiência que irá transformar aquele que a experimenta. O "sujeito" da experiência da arte, o que fica e persevera, não é a subjetividade de quem a experimenta, mas a própria obra de arte. (GADAMER,1997, p.175)

Interpretar uma obra é colocar em jogo as concepções prévias que já trazemos conosco sobre o que pode emergir nessa relação como um sentido possível. Esse surgimento de significados propiciado pela experiência é que libera a questão da verdade, pois cria o âmbito em que ela pode aparecer. O jogo é o lugar em que a pergunta pela verdade se tornaria possível. Essas concepções 
prévias não são somente aquelas relativas ao que sabemos sobre a biografia do artista, ao contexto de criação da obra, à escolha do material que foi usado e até mesmo àqueles preconceitos fomentados pela legenda que foi posta na obra. Nossa aproximação em direção à obra é guiada pelas antecipações que constituem a expectativa sobre o que ela pode nos dizer. Gadamer fala que o mesmo ocorre quando lemos um texto:

Quem quiser compreender um texto realiza sempre um projetar. Tão logo apareça um primeiro sentido no texto, o intérprete prelineia um sentido do todo. Naturalmente que o sentido somente se manifesta porque quem lê o texto a partir de determinadas expectativas e na perspectiva de um sentido determinado. A compreensão do que está posto no texto consiste precisamente na elaboração desse projeto prévio, que obviamente, tem que ir sendo constantemente revisado com base no que se dá conforme se avança na penetração do sentido. (GADAMER, 1997, p.170)

Da mesma maneira, para Gadamer, a possibilidade de "ler" uma pintura, por exemplo, dá-se quando reconhecemos o que nela se apresenta a partir de nosso próprio manancial de experiências. Isso só é possível, portanto, porque ao ver uma obra entramos em um jogo no qual "ficamos testando variáveis de agrupamento ou ficamos oscilando entre elas" e então, somente quando entendemos a obra, “quando ela se torna 'clara' para nós, é que vem a ser para nós uma configuração artística" (GADAMER, 1997, p.161). Com isso, Gadamer nos leva a pensar acerca do fato de que a percepção da obra diz respeito ao seu significado, uma vez que apenas olhar para a obra como um mero objeto não é o suficiente para que ela seja compreendida. Enquanto não alcançamos o seu significado, ela não se mostra para nós em sua totalidade. Por isso, para Gadamer: “o mero ver, o mero ouvir são abstrações dogmáticas, que reduzem artificialmente os fenômenos. A percepção abrange sempre o significado" (GADAMER, 1997, p.162).

Nesse sentido, Gadamer também afirma que a qualidade estética de uma obra repousa sobre "as leis de construção" e estão "em um nível de formulação" que ultrapassam as barreiras da procedência histórica e pertença cultural. Evidentemente, ele leva em conta que a formação do gosto estético se dá a partir de contextos históricos e culturais, que já prelineiam e modulam o próprio gosto pessoal. Contudo, Gadamer eleva a questão a uma experiência que ultrapassaria todo o historicismo: 
Talvez pareça até plausível distinguir entre o contexto originário de mundo que funda uma obra de arte, e a sua sobrevivência nas situações de vida modificadas do mundo posterior àquele. Porém, onde se separa propriamente mundo e mundo posterior? (...) Dever-se-ia reconhecer e admitir que uma antiga imagem de deuses, por exemplo, que não foi representada no templo como obra de arte para um desfrute estético da reflexão, e que hoje tem a sua representação no museu moderno, contém em si o universo da experiência religiosa, da qual ela procede, tal como ela se nos apresenta hoje, e isto tem a consequência significativa de que esse seu mundo pertence ainda ao nosso mundo. É o universo hermenêutico que abarca a ambos. (GADAMER,1997, p.17 e 18).

Gadamer fala dessa formação estética que nos permite entrar em contato com o que há de mais "puro" na obra de arte. Aquilo que na obra a diferencia em sua qualidade e a faz extrapolar o seu contexto originário. A esse momento da formação estética, Gadamer dá o nome de "diferenciação estética". A diferenciação estética não persegue um padrão de conteúdo, e por isso também não leva em conta a filiação da arte com o seu mundo. Ela se atém a manter uma relação com a qualidade estética. Sendo assim, não seleciona ou rejeita com base no gosto, por ser ele sempre local e temporal. Tudo o que é aderente a essa obra verdadeira são momentos extraestéticos: fim, função, significado de conteúdo. Esses momentos podem ser significativos na medida em que incorporam a obra ao seu mundo, o que determina uma abundância de significados. Existiria, então, uma diferença entre tudo o que é intencionado esteticamente - tudo o que diz respeito à natureza artística da obra - e tudo o que é extraestético na obra de arte.

De acordo com Gadamer, toda pessoa que experimenta a verdade na obra de arte realiza na plenitude dessa experiência uma autocompreensão, na medida em que a obra de arte significa algo para ela. Isso se dá para além dos contextos de mundo que fundam uma obra e os contextos posteriores, nos quais ela sobrevive e ainda é capaz de dizer algo.

Também a experiência estética é uma forma de compreender-se. Todo compreender-se se completa, porém, em algo diferente do que aí se compreende, e inclui a unidade e a mesmidade desse diferente. Uma vez que encontramos no mundo a obra de arte e em cada obra de arte individual um mundo, este não continua a ser um universo estranho em que, por encantamento, estamos à mercê do tempo e do momento. Nele, mais do que isso, aprendemos a nos compreender, e isso significa que suspendemos a descontinuidade e a pontualidade da vivência na continuidade da nossa existência. (GADAMER, 1997.p.168)

Gadamer intitula a segunda parte de Verdade e Método I como A Extensão da Questão da Verdade à Compreensão nas Ciências do Espírito. Mais uma vez, ele segue a metodologia do diálogo com diferentes autores da tradição filosófica, 
principalmente, com Schleiermacher, Dilthey, Husserl e Heidegger até chegar à elaboração rigorosa dos conceitos que servirão de base para a sua hermenêutica. Nesse ponto, Gadamer adentra a questão do desenvolvimento da hermenêutica moderna. Podemos colocar, então, a pergunta: o que é a hermenêutica afinal?

A hermenêutica entendida como arte, e também como técnica de interpretação, na interpretação bíblica e nas investigações filológicas dos textos clássicos de difícil compreensão possui uma longa história. Ela, contudo, ganha sua condição de corrente de pensamento filosófico apenas no início do século XIX com Schleiermacher, que propôs sua reformulação baseando-se na crença de que era possível formular uma "hermenêutica geral". Sua tarefa seria estabelecer os princípios sobre os quais toda a compreensão de qualquer manifestação linguística se apoiaria. É dessa ideia que deriva a afirmação de que tudo aquilo que é objeto da compreensão e da interpretação é linguagem ${ }^{8}$. Com isso, Schleiermacher descreve a compreensão humana como uma estrutura circular, a princípio de maneira formal, e eleva a hermenêutica a uma questão filosófica.

Gadamer compreende que a hermenêutica moderna, ao seguir o caminho da "reconstrução", tal como proposto por Schleiermacher, ter-se-ia afastado de seu sentido mais original, que era o da "integração", como observa Schmidt (2017, p.141). A tarefa primordial da hermenêutica não era a de reconstruir na compreensão a determinação original de algo que chega desenraizado de seu mundo original (GADAMER, 1997, p.265), mas a de trazer à luz os significados possíveis que são liberados pelo texto e, mais do que isso de integrar essas possibilidades em nossa própria vida. Gadamer percebe que Schleiermacher se afasta dessa tarefa hermenêutica de "integração" e se emprenha em outra tarefa, a de "reconstrução". Gadamer se dá conta de que a noção de reconstrução deixa de fora algo que é decisivo, isto é, o efeito incontornável do interpretado sobre nós.

Schleiermacher, com sua "teoria geral da compreensão", descreveu o movimento circular da compreensão como sendo um movimento constante que vai do todo à parte e desta novamente ao todo. $\mathrm{O}$ método para a correção de uma compreensão seria a busca da concordância que cada parte necessariamente teria com o todo. Schleiermacher também entrelaçava em sua teoria aspectos objetivos

\footnotetext{
${ }^{8}$ BRAIDA, Celso R.. Aspectos semânticos da hermenêutica de Schleiermacher. In: Róbson R. dos Reis; Ronai P. da Rocha. (Org.). Filosofia hermenêutica. Santa Maria: Ed. UFSM, 2000, v. , p. $23-$ 38.
} 
e aspectos subjetivos, referentes à individualidade ou à essência daquele que escrevia a obra:

Tal como cada palavra forma parte do nexo ${ }^{9}$ da frase, cada texto forma parte do nexo da obra do autor, e esta forma parte, por sua vez, do conjunto do correspondente gênero literário e mesmo de toda a literatura. Mas por outro lado, o mesmo texto pertence, como manifestação de um momento criador, ao todo da vida da alma de seu autor. (GADAMER, 1997, p.437)

Mais do que compreender a verdade da obra, Schleiermacher considerou que era tarefa central do intérprete reconstruir, além das condições originais de surgimento da obra, todo o processo criativo pelo qual ela passou, para se chegar a compreender também aquilo que era intencionado pela subjetividade do autor. Schleiermacher, desse modo, acaba recorrendo aos conceitos de interpretação congenial e divinatória, como um movimento de "transferir-se para dentro da constituição completa do escritor, um conceber o decurso interno da feitura da obra" (GADAMER, 1997, p.292). Gadamer, contudo, argumenta que a reconstrução seria uma empreitada fracassada: "o quadro devolvido do museu para a igreja, ou o edifício reconstruído segundo o seu estado antigo não são o que foram - se convertem em objeto para turistas" (GADAMER, 1997, p.266). Para ele, aquilo de que fala o autor, ou seja, o assunto em discussão no modo como ele nos afeta, "a coisa ela mesma" (die Sache selbst) ${ }^{10}$ da fenomenologia, formulação a que Gadamer recorre reiteradas vezes em seu texto, é o que deveria ser o verdadeiro objeto da interpretação.

A descrição da estrutura da compreensão proposta por Heidegger representa uma mudança decisiva, justamente por colocar o aspecto subjetivo de lado e buscar uma fundamentação mais apropriada para o círculo hermenêutico. Segundo Jonathan Rée, Heidegger percebe “que todos nós já entendemos o que é o ser, sem ter sequer de pensar sobre ele - afinal, qualquer criança sabe usar o verbo "ser"" (RÉE, 2000, p.12). Por isso, “se temos, de algum modo, uma compreensão adequada do que é ser, então devemos reconhecer que essa 'compreensibilidade mediana' não educada é ela mesma um fato importante, que merece análise atenta

\footnotetext{
${ }^{9}$ É interessante destacar que "nexo" é a tradução da palavra Zusammenhang, que quer dizer mais exatamente conexão ou contexto. A própria palavra em alemão carrega em si a indicação de que a parte, a palavra, precisa ser entendida a partir do contexto, com sua conexão com um todo.

${ }^{10} C f$. GADAMER, Hans-Georg. A natureza da coisa (Sache $=$ coisa em questão) e a linguagem das coisas (Dinge) (1960) in Verdade e Método II. Tradução de Enio Paulo Giachini. 2. ed. Petrópolis: Vozes, 2002.p. 81-94
} 
e paciente" (RÉE, 2000, p.12). Desse modo, ele coloca mais uma vez a antiga questão filosófica sobre o sentido do "ser" em sua mais conhecida obra: Ser e Tempo. Para Heidegger, o que distingue o ente dotado do caráter de ser-aí $(\text { Dasein })^{11}$, o existente, o modo de ser que nós incorporamos quando lançados na nossa vida histórica, dos demais entes é justamente o seu privilégio ontológico, isto é, de compreender o "ser" dos entes, o que não ocorreria com nenhum outro ente. Assim, o traço mais característico do ser humano é a sua capacidade de compreender e conseguir se orientar em um mundo que desde sempre aparece para ele como um mundo que propicia uma unidade de sentido, um sentido que ele já compartilha com os outros e do qual participa com os outros. A circularidade presente nessas formulações é evidente e fica mais clara ainda na seguinte afirmação de Gadamer:

O movimento da compreensão vai constantemente do todo à parte e desta ao todo. A tarefa é ampliar a unidade do sentido compreendido em círculos concêntricos. O critério para a correção da compreensão é sempre a concordância de cada particularidade com o todo. Quando não há tal concordância, isso significa que a compreensão malogrou. (GADAMER, 1997, p. 436)

De acordo com Schmidt, "Heidegger revela que a compreensão é uma estrutura ontológica fundamental do ser humano" (SCHMIDT, 2014, p.145). Isto significa que nosso existir já sempre acontece a partir de alguma forma de compreender o nosso ser, o ser dos outros entes como nós e o ser das coisas que nos circundam. Mesmo sobre aquilo que se revela como algo novo para nós, ou até mesmo sobre algo que julgamos não saber exatamente do que se trata, já temos alguma compreensão prévia. Um exemplo que podemos tomar no campo da educação é a noção de que podemos e devemos conversar com as crianças, mesmo com as bem pequenas, sobre assuntos que parecem a princípio muito complexos. Com frequência, somos pegos em situações em que tentamos, por meio da escolha de palavras mais simples e objetivas, explicar o que significam tais assuntos. O que ocorre é que, por sua inserção no mundo, a criança, desde

\footnotetext{
${ }^{11}$ Heidegger utiliza o termo Dasein para se referir ao modo de ser do ser humano. O termo é resultado da união da forma verbal e nominal sein (ser ou estar) com a palavra $d a$, que no alemão comporta diferentes significados. A palavra $d a$ pode ser utilizada para indicar um lugar: "lá", "aqui", "ali", "aí" etc., como para indicar o tempo: "então" e "desde". O da também pode expressar o sentido de: "pois", "porquê", "então" etc. Os sentidos de lugar e tempo da palavra $d a$ se entrelaçam no termo Dasein na filosofia heideggeriana. Na tradução para o português, o termo "ser-aí" tem sido o mais bem aceito. Nele temos incorporada a ideia de um ser (que é também um estar) localizado espacialmente e temporalmente em " $d a$ ", ou seja, em um "aí" que é um mundo. Pelo fato de " $d a$ " ser uma palavra plurissignificativa, o Dasein assume ao mesmo tempo um passado vivo, um "então" $(d a)$, que é realizado no "aqui" ( $d a)$ presente, mas que também se projeta em um lá $(d a)$ futuro. Acerca do conceito de ser-aí, $C f$. FERREIRA JÚNIOR, 2009, p.38 (nota 29).
} 
sempre, já participa de situações sociais em que ela precisa se comportar de modo adequado às expectativas do meio no qual ela se insere, caso contrário, ela será repreendida, advertida ou simplesmente não conseguirá ter sucesso em suas ações. O que Heidegger apresenta como ideia de compreensão de ser é que, compreender é atender às requisições do mundo, mais especificamente, das circunstâncias fáticas que a circundam, a partir de determinados comportamentos sedimentados, e não do uso de suas faculdades cognitivas. Para Heidegger na compreensão está tudo aquilo que o ser-aí (Dasein) pode ser:

Por vezes num discurso ôntico, usamos a expressão "compreender alguma coisa" com o sentido de "estar a cavaleiro de...", "estar por cima de...", "poder alguma coisa". O que se pode na compreensão enquanto existencial não é uma coisa, mas o ser como existir. Pois na compreensão subsiste, existencialmente, o modo de ser do ser-aí enquanto poder-ser. O ser-aí ${ }^{12}$ não é algo simplesmente dado que ainda possui de quebra a possibilidade de poder alguma coisa. Primariamente, ele é possibilidade de ser. Todo ser-aí é o que ele pode ser e o modo em que é a sua possibilidade. (HEIDEGGER, 2001, p. 198/199)

Isso significa que a criança já sempre estabeleceu uma lida hermenêutica com seu mundo, descobrindo em comportamentos as orientações que esse mundo fornece, ajustando e reajustando suas ações a cada nova situação. Ou seja, antes mesmo e para além das instruções teóricas provenientes da educação escolar, é o próprio agir da criança no mundo que, em primeiro lugar, requer que ela eduque a si mesma, no sentido em que Gadamer fala em Educar é educar-se. Portanto, o processo de aprendizado se funda, antes de tudo, no modo de ser hermenêutico do agir humano, em vez de se fundar em faculdades cognitivas e, consequentemente, em instituições destinadas a desenvolver essas faculdades.

Ainda segundo Heidegger, na compreensão, o ser-aí projeta possibilidades de seu próprio ser, e por ele ser-em-um-mundo, em um "aí" específico, ele se descobre desde sempre em um contexto histórico, articulado a um momento presente que já carrega em si uma relação com o passado. Por conta disso, "qualquer compreensão ou reivindicação de verdade depende do horizonte temporal em que o Dasein vive e de sua interpretação projetiva de suas possibilidades de ser" (SCHMIDT, 2014, p.145). Com isso, Heidegger devolve à hermenêutica a sua tarefa mais original, que é a de integração, demonstrando que a compreensão é a realização do ser no mundo.

\footnotetext{
${ }^{12}$ Substituímos o termo pre-sença por "ser-aí", pois esta tem sido a forma mais aceita entre os
} estudiosos especialistas na filosofia de Heidegger de traduzir o termo original alemão (dasein). 
Para Gadamer, se há algum deslocamento quando procuramos entender um texto, este deslocamento não é em direção à subjetividade do autor, mas sim em direção à perspectiva "sob a qual o outro ganhou a sua própria opinião" (GADAMER, 1997, p.437), o que só é possível na medida em que projetamos um horizonte em comum, no qual se fundem o horizonte do autor e o nosso próprio. É mais precisamente isso que Gadamer tem em mente com a sua ontologia do diálogo, ou seja, ao pensar o diálogo como uma condição de ser da interpretação, pois quando buscamos interpretar o que nos diz o outro, podemos reforçar os argumentos trazidos pelo nosso interlocutor, na medida em que os atualizamos. Diante disso, Gadamer chega à conclusão de que seria "tarefa da hermenêutica explicar esse milagre da compreensão, que não é uma comunhão misteriosa entre almas, mas uma participação num sentido comum" (GADAMER, 1997, p.438). É preciso dizer aqui que esse sentido comum não possui um caráter metafísico, pois ele é fruto do encontro dos diversos que revela o caráter problemático da compreensão.

O que é central é entender que a noção de compreensão, trazida por Heidegger, é a de que tudo aquilo que sabemos já se encontra determinado, de forma contínua, "pelo movimento de concepção prévia da pré-compreensão" (GADAMER, 1997, p.439). Essa circularidade é o que permite chegarmos ao sentido mais original de algo, uma vez que este sentido não paira sobre nós como um ente extramundano e nem está dentro de uma subjetividade que necessita ser reconstruída.

Nesse mesmo sentido, a tese de Gadamer sobre as investigações das ciências do espírito é a de que "mesmo lá onde a metodologia das modernas ciências históricas ganhou espaço, e torna em "objeto" aquilo que veio a ser historicamente o que foi transmitido historicamente, o qual se tem que "constatar" como um dado experimental" (Gadamer, 1997, p. 22), é o momento históricoefeitual (Wirkungsgeschichtliches Moment) o que permanece efetivo e atuante em todo compreender da tradição. Ou seja, o que torna possível a investigação científica e a própria compreensão do sentido daquilo que é investigado é também algo que a antecede e a orienta. O que orienta a escolha do objeto, do método e a interpretação dos resultados não é nada senão o conhecimento prévio, a compreensão prévia daquilo que veio a ser objeto. Em linhas gerais, o que Gadamer chama de "momento histórico-efeitual" ou "consciência histórico- 
efeitual" (GADAMER, 1997, p.505) é tanto ter, por um lado, uma consciência que é afetada no curso da história e determinada por ela, quanto, também, ter consciência desse próprio ser afetado.

Dessa forma, a partir da estrutura da compreensão que adota de Heidegger, Gadamer desenvolve, nesta segunda parte da obra, algumas questões que serão basilares em sua hermenêutica, como as noções de: preconceito, horizonte, tradição, distância temporal, história efeitual, interpretação, aplicação, autoridade e diálogo. Sobre estas questões, contudo, nos debruçaremos apenas mais adiante nesse capítulo e no segundo capítulo deste trabalho.

A terceira parte de Verdade e Método I intitula-se A Virada Ontológica da Hermenêutica no Fio Condutor da Linguagem. Nela, Gadamer, argumenta que "a linguagem é o medium universal em que se realiza a própria compreensão" (GADAMER, 1997, p.566). Ele inicia sua exposição tomando como exemplo a experiência do diálogo, o que nos leva a refletir sobre o que nos ocorre quando entramos em diálogo com outra pessoa. O diálogo nesse momento tem o sentido de Gespräch, ou seja, uma conversação onde duas pessoas confrontam suas interpretações. Gadamer argumenta que, quanto mais autêntica é uma conversação menos se tem um controle sobre o que se fala. É como se "uma palavra puxasse a outra" e os interlocutores se deixassem levar por ela. Por isso, essas seriam "formas de expressar que a conversação tem seu próprio espírito e que a linguagem que nela discorre leva consigo a sua própria verdade, isto é, 'revela' ou deixa aparecer algo que desde este momento é." (GADAMER, 1997, p.559). O entendimento (Verständigung) entre os interlocutores tem como centro o próprio assunto em questão e a conversação se dá pelo entendimento entre eles sobre esse assunto. Desse modo, o que permite "compreender o que alguém diz é (..) pôr-se de acordo sobre a coisa, não o ato de se deslocar para dentro do outro e reproduzir suas vivências." (idem). Isto nos leva a perceber que o processo de compreensão é um processo que se estrutura linguisticamente, uma vez que o sentido da coisa se expressa linguisticamente durante a conversação (diálogo).

Gadamer traz também o exemplo do texto traduzido de uma língua estrangeira, que mostra que o que permite a alguém compreender um texto é, antes de tudo, compreender a língua na qual ele está escrito. Contudo, compreender uma língua não é somente ser capaz de traduzi-la para a sua própria língua, isto é, encontrar a correspondência daquilo que se fala em uma língua que 
nos é familiar. Para Gadamer, compreendemos uma língua estrangeira quando não precisamos fazer a tradução dela para a nossa própria língua, uma vez que para ele “compreender uma língua não encerra nenhum processo interpretativo, mas é uma realização vital. Pois, compreende-se uma língua quando se vive nela" (GADAMER, 1997, p.561). Nesse sentido, só conseguimos entrar em conversação com um texto que se encontra em uma língua com a qual, em princípio, não estamos familiarizados, quando não precisamos mais que ele seja traduzido para nossa língua materna. Sobre a tradução, Gadamer nos leva a observar que:

Este agenciamento artificial não é, evidentemente, o caso normal das conversações. Tampouco, a tradução é o caso normal de nosso comportamento com respeito a uma língua estrangeira. Antes, o fato de depender da tradução é como que uma renúncia da autonomia por parte do interlocutor. Quando a tradução é necessária, não há outro remédio a não ser dar-se conta da distância entre o espírito da literalidade originária do que é dito e o de sua reprodução, distância que nunca chegamos a superar por completo. (GADAMER, 1997, p.560).

Assim, para Gadamer, quem lê um texto traduzido, também estabelece uma conversação, contudo, essa conversação, ou diálogo, dá-se entre o leitor e o que foi interpretado e, então, o resultado da conversação é reproduzido na tradução do texto original. Assim, ficamos privados de uma compreensão direta das nuances da língua em que ele foi escrito originalmente. Uma vez que não conseguimos nos mover no horizonte de sua expressividade primária, não compreendemos tais nuances em uma tradução, a não ser que passemos a tomar parte na fala original. Portanto, a qualidade da reprodução dependerá da habilidade do tradutor em reconhecer e reiluminar essas nuances, a fim de que elas possam ser expressas na sua própria língua. Isto implica reconhecer que em diversas situações ele precisará "fazer escolhas e resignar-se" diante da impossibilidade de transpor para outra língua, sem algum prejuízo, o sentido do texto original, como reconhece Gadamer (idem).

A própria tarefa do intérprete de propiciar a "ressurreição do sentido do texto" (GADAMER, 1997, p.566) já se encontra sempre implicada pelo horizonte de quem interpreta "como uma opinião e possibilidade que se aciona e coloca em jogo e que ajuda a apropriar-se de verdade do que diz o texto." (idem). Desse modo, também ocorre entre o intérprete e o texto uma fusão de horizontes, o que significa dizer que um intérprete não pode escapar de sua própria situação para 
alcançar um ponto de vista neutro. Nesse sentido, a ideia de haver um círculo hermenêutico da compreensão se apresenta mais claramente. Os preconceitos que permitem a interpretação do texto já se encontram previamente em um horizonte ${ }^{13}$ histórico maior que une os dois horizontes, tanto o do texto original quanto o do intérprete.

O que Gadamer busca tornar claro com os exemplos da conversação e da tradução é a "linguisticidade" da compreensão e o fato de que todo compreender é um interpretar a partir de um horizonte de sentido. Esse horizonte se constitui linguisticamente e, por isso, "todo interpretar se desenvolve no medium de uma linguagem que pretende deixar falar o objeto e é, ao mesmo tempo, a linguagem própria de seu intérprete”. (GADAMER, 1997, p.567)

A partir dessa introdução, Gadamer analisa o privilégio que a língua escrita tem em poder reunir simultaneamente passado e presente e a possibilidade autêntica que ela traz para o leitor de se deslocar, de ampliar seus horizontes e enriquecer seu mundo:

A apropriação da tradição literária supera inclusive a experiência que se vincula com a aventura do viajar e do submergir-se em mundos linguísticos estranhos. O leitor que se aprofunda numa língua e literatura estrangeira mantém, a todo momento, a liberdade de voltar de novo a si mesmo, e está assim ao mesmo tempo aqui e acolá. (GADAMER, 1997 p.568)

Um texto escrito, como uma espécie de fala que se torna alheia a quem a pronunciou, necessita sempre "da reconversão de seus signos à fala e ao sentido" (GADAMER, 1997 p.573), de acordo com Gadamer, e nisso se encontra a verdadeira tarefa hermenêutica. O sentido do que foi dito volta a ser enunciado com base unicamente no que foi transmitido pelos signos escritos. Por isso, "o que diz no texto tem de ser despojado de toda a contingência que lhe é inerente, e entendido na plena idealidade em que unicamente tem seu valor". (GADAMER, 1997 p.574). Como vimos anteriormente, na crítica de Gadamer a Schleiermacher, somente assim ele é capaz de nos dizer algo de verdade e promover alguma integração em nossa vida, que culminaria em uma autocompreensão. Caso contrário, ele se torna um objeto das ciências históricas, incapaz de exercer sobre o presente qualquer influência decisiva.

\footnotetext{
${ }^{13}$ Sobre a ideia de horizonte, falaremos mais profundamente no tópico 2.5 do segundo capítulo.
} 
Os desdobramentos dessa análise irão percorrer alguns caminhos dentro da terceira parte da obra de Gadamer, como a própria cunhagem do conceito de "linguagem" no mundo ocidental. Nesse ponto, Gadamer começa a discussão baseando-se no Crátilo de Platão, em que ele examina a teoria "convencionalista" e a teoria da "semelhança", que são duas teorias sobre a relação entre palavra e a coisa que é nomeada. Gadamer vai dizer que ambas pressupõem que conhecemos primeiro a coisa e que depois a nomeamos, mas, para o autor, o que de fato ocorre é que a coisa somente se releva para nós quando a palavra correta é encontrada. Ele segue a análise se aproximando dos conceitos de "linguagem divina" e "linguagem humana" de Tomás de Aquino, passando pelo conceito de "visão de mundo" (Weltansicht) de Humboldt, até chegar à "intencionalidade" de Husserl e, enfim, mais adiante retomar a ideia da linguagem como horizonte de uma ontologia hermenêutica, na qual finalmente retoma a ideia de que herdamos nossos preconceitos da tradição com a qual nos encontramos unidos. Estes preconceitos constituem nosso horizonte linguístico de significado possível:

(...) nesse sentido seria literalmente mais correto dizer que a linguagem nos fala que dizer que nós falamos a ela (...) que a linguagem não constitui o verdadeiro acontecer hermenêutico enquanto linguagem, enquanto gramática nem enquanto léxico, mas no vir à fala do que foi dito na tradição, que é ao mesmo tempo apropriação e interpretação. Por isso, é aqui onde se pode dizer com toda razão, que esse acontecer não é nossa ação na coisa, mas a ação da própria coisa. (GADAMER, 1997, p.672)

Cabe ressaltar que, neste trabalho, não nos limitamos a ter como referência única a obra Verdade e Método I, mas esta será sem dúvidas nossa principal referência. A escolha metodológica de começar este trabalho pela introdução à obra que nos servirá como base se deu com a intenção de aproximar o leitor de uma visão global daquele que foi o caminho escolhido por Gadamer para desenvolver e apresentar sua hermenêutica filosófica.

Tendo em vista todo o arcabouço teórico construído no campo da hermenêutica acerca dos conceitos de compreensão, preconceito, tradição, horizonte histórico e diálogo, elegemos como temas basilares desse estudo as noções de preconceito e diálogo, que servirão como fio condutor da discussão. Existem diferentes possibilidades de entrar na obra de Gadamer e aproximá-la das questões emergentes no campo da educação. A maneira que escolhemos aqui foi partir da exposição dos conceitos de diálogo e preconceito, pois entendemos que 
eles nos remetem para a reflexão acerca da autoridade legítima, da fusão e ampliação de horizontes de formação e, sobretudo, para a possibilidade de compreender a existência e a influência dos diferentes horizontes históricos implicados no processo educacional. Compreendemos que estes temas são recorrentes quando o assunto é a diversidade cultural, mas que, ao mesmo tempo, a sua autoevidência é apenas aparente. Como já foi dito, o debate acerca de tais questões se faz necessário, uma vez que a má compreensão sobre esses conceitos tem um reflexo direto na nossa postura diante das situações.

Se no senso comum acreditamos que é exatamente a existência do preconceito aquilo que impede o diálogo, na aproximação com a hermenêutica gadameriana temos um forte indício de que é justamente o contrário o que ocorre. Sendo assim, ao contrário do que parece, o diálogo só se tornaria possível pela primazia dos preconceitos. Assumindo essa premissa como verdadeira, somos levados a repensar a relação entre preconceito e diálogo. Abrimos então um novo campo para colocarmos a questão sobre a diversidade e a formação humana.

A educação que, na concepção de Gadamer ${ }^{14}$ só se viabiliza por intermédio do diálogo, assume um lugar privilegiado como questão filosófica. A educação, então, seria um lugar privilegiado para colocarmos nossos preconceitos em jogo, atestamos ou não sua legitimidade e nos educarmos com o outro.

${ }^{14} C f$. GADAMER, Hans-Georg. La educación es educarse. Barcelona: Piados, 2000. 


\section{2}

\section{Apresentação dos conceitos fundamentais}

Para Heidegger, como já dissemos acima, a compreensão é uma estrutura existencial fundamental do ser-aí. Isso significa que desde sempre já estamos imersos em uma determinada compreensibilidade, ou seja, desde sempre partimos de concepções prévias, ou pré-ontológicas, que a nossa inserção no mundo nos fornece. Não seria então possível encontrar um marco zero da compreensão. Até mesmo antes de tomarmos consciência sobre nós mesmos, já temos uma lida compreensiva com o mundo ao qual pertencemos. Como descreve Schmidt, "Enquanto projeção, a compreensão trata das possibilidades futuras do ser humano e culmina na autocompreensão" (SCHMIDT. 2017, p.145). Dessa forma, todo ato de compreensão se apoia em estruturas prévias que já foram sendo construídas ao longo do tempo, não somente nos indivíduos, mas na tradição à qual ele pertence. Também o conceito de compreensão precisa, nesse caso, se desvencilhar de alguns modos como ele tende a ser concebido, como bem avalia Gadamer:

Compreender não é um ideal resignado da experiência de vida humana na idade avançada do espírito, como em Dilthey, mas tampouco, como em Husserl, um ideal metódico último da filosofia frente à ingenuidade do ir-vivendo, mas ao contrário, é a forma originária de realização do ser-a $\imath^{15}$, que é ser-no-mundo. (GADAMER, 1997, p.392)

Compreender significa estar inserido em um mundo (em uma tradição). É essa inserção, que é também um pertencimento, o que nos permite elaborar projetos e fazer antecipações sobre o sentido das coisas. Antecipações que, como afirma Gadamer, "devem ser confirmadas "nas coisas"” (GADAMER, 1997, p. 402), o que remete à estrutura circular de todo compreender.

Embora a estrutura circular da compreensão já tenha sido percebida na hermenêutica do século XIX, a descrição e a fundamentação do círculo hermenêutico, feita por Heidegger, representa uma mudança decisiva. E é a própria circularidade da compreensão o que nos possibilita reelaborar constantemente nossas opiniões prévias, ou seja, nossos preconceitos e as antecipações interpretativas que fazemos a respeito das coisas. A tradição

\footnotetext{
${ }^{15}$ Acompanhando a primeira tradução de Ser e Tempo, o tradutor da edição aqui utilizada de Verdade e Método I também traduziu Dasein por "pré-sença". Optamos nesse trabalho, no entanto, por utilizar o termo ser-aí.
} 
herdada, à qual nós aderimos e da qual nos tornamos parte em nossa inserção em um mundo, torna-se o ponto de partida de todo ato de compreensão. Ou seja, desde nossas primeiras ações, nós nos inserimos nesse ciclo constante de elaboração e revisão de projetos prévios. Com isso, nos tornamos parte de uma tradição que se revela no modo como agimos interpretativamente em nosso mundo.

Como nos chama a atenção Schmidt, a escolha de Gadamer pelo termo "preconceito" não se dá por acaso. Enquanto Heidegger descreve a circularidade hermenêutica da compreensão como sendo a estrutura fundamental do ser humano, "a tarefa de Gadamer na hermenêutica filosófica é demonstrar como se pode obter a compreensão correta fundamentando as estruturas prévias da compreensão nas coisas em si” (SCHMIDT. 2017, p.146). É importante destacar aqui que o que Gadamer compreende como o "em si" da coisa tem o caráter provisório daquilo que foi construído e sedimentado historicamente. Gadamer deseja examinar a compreensão de um ponto de vista ontológico, mas não deixa de fazê-lo também de um ponto de vista epistemológico. Para Gadamer, alcançar a compreensão correta nos oferece uma "experiência de verdade", de ter alcançado o conhecimento sobre algo. A verdade sobre aquilo que desejamos conhecer, ou o conhecimento sobre algo, só é possível no constante projetar e revisar de preconceitos.

Gadamer deseja chamar a atenção para o fato de que toda a conotação negativa que temos sobre a palavra "preconceito" começa a se construir por fomento da Aufklärung. Como veremos a seguir, a Aufklärung incentivava e valorizava o uso da nossa razão contra a aceitação de qualquer autoridade que se fundasse na tradição. A tradição era entendida como um manancial de preconceitos que orientava as pessoas de tal modo, que estas eram levadas a fazer pouco uso sua própria razão. Gadamer, em resposta ao que se pensou na Modernidade, deseja tornar evidente a facticidade histórica do conhecimento e, inclusive, da própria razão.

Para adentrarmos mais profundamente nessa discussão, apresentaremos a seguir como os preconceitos herdados da tradição foram questionados na Modernidade sob o lema da Aulfklärung, que pregava a saída da menoridade como uma das condições para o progresso da própria humanidade. Em seguida, a 
crítica gadameriana ao projeto da Modernidade e, ao mesmo tempo, as possibilidades que essa reflexão pode nos abrir no campo do conhecimento.

Entendemos que essa discussão ainda se faz necessária, sobretudo no campo da educação, pois ela nos fornece reflexões importantes, a partir de um ponto de vista hermenêutico, sobre o modo como conduzimos a nós mesmos em busca do conhecimento.

\section{1}

\section{A Aufklärung e o pensamento kantiano: razão e preconceito}

Immanuel Kant é sem dúvida a referência principal que temos quando falamos da Aufklärung, movimento intelectual europeu do século XVIII também conhecido como Iluminismo, Ilustração, Época das Luzes (Lumières, em francês), ou Esclarecimento. Sobre a tradução do termo para a língua portuguesa, Bicca (1997, p.49) advoga que o termo "Esclarecimento" seria o que melhor guardaria o sentido "de um processo geral que perpassa épocas e culturas diversas" o que não ocorre com os termos Iluminismo e Ilustração. Segundo o autor, "o conceito de Esclarecimento, na medida em que possui o sentido de processo, significa algo inacabado, voltado por excelência para o futuro" (BICCA, 1997, p.49). Essa teria sido a maneira como Kant concebeu esse processo, que não seria possível de ser realizado apenas por um indivíduo, mas por toda a humanidade ao longo de gerações.

Para alguns estudiosos (CAYGILL, 2000, p.183), a Aufklärung teria passado por três fases distintas na Alemanha. A primeira delas, a fase racionalista, que surge no início do século na Universidade de Halle com Thomasius e Christian Wolff. Ambos haviam incentivado o uso do alemão no lugar do latim acadêmico na redação dos textos, por acreditarem que suas obras deveriam ser levadas para além das fronteiras da universidade. Por suas ideias revolucionárias que afirmavam que deveria ser possível justificar racionalmente tudo, inclusive a existência de Deus, Wolff sofreu enorme pressão política e acabou sendo forçado a deixar a Prússia em 1723. Já em Marburg, Wolff foi recebido com entusiasmo e atraiu um enorme número de estudantes. Reescreveu em latim seu sistema, que abrangia princípios da lógica, metafísica, ética, política e ciências econômicas, esperando que este alcançasse uma abrangência internacional. Chegou a retornar à 
Prússia quando Frederico II sucedeu seu pai, Frederico I, mas quase vinte anos haviam se passado e o caráter da Aufklärung já havia mudado. Os grandes sistemas que impulsionavam o exercício de uma razão abstrata haviam dado lugar aos ensaios céticos, que tinham por modelo os de David Hume.

A essa segunda fase da Aufklärung pertencem os escritos pré-críticos de Kant, como, por exemplo, Observações Sobre o Sentimento do Belo e do Sublime de 1764. Numa revisita ao sistema de Wolff, em 1781, o autor dá início à terceira fase da Aufklärung com a publicação da Crítica da Razão Pura. Nessa obra, Kant busca bases sólidas para uma teoria do conhecimento. Bases tão sólidas quanto as que a física e a matemática newtonianas teriam conseguido alcançar para a consolidação metodológica das ciências naturais. Dessa forma, em sua primeira crítica, ele assumiu a tarefa de responder as questões "como são possíveis os juízos sintéticos a priori na matemática?"; “como são possíveis os juízos sintéticos a priori na física?" e, “como são possíveis os juízos sintéticos a priori na metafísica?" (KANT, 1980, p.16).

Em linhas gerais, nas duas primeiras partes da sua primeira crítica - Estética Transcendental e Analítica Transcendental -, Kant dedicou-se à busca dos juízos a priori que poderiam garantir o conhecimento da matemática e da física, para finalmente na Dialética Transcendental, analisar do uso das categorias do entendimento e mostrar as antinomias que resultam do mau uso da razão. Kant chega à conclusão de que o que confere à matemática e à física o título de "disciplinas científicas" é o fato de estas disciplinas corroborarem de modo bastante claro a sua teoria sobre as condições a priori do conhecimento. Já na Dialética Transcendental, Kant se coloca a questão sobre a possibilidade do mesmo título poder ser estendido à Metafísica, que tinha objetos de análise bastante diversos das outras ciências: a existência de Deus, a liberdade e a imortalidade.

A ciência, porém, cujo propósito último está propriamente dirigido com todo seu aparato só à solução desses problemas denomina-se Metafísica; o procedimento desta é de início dogmático, ou seja, assume confiantemente a sua execução sem um exame prévio da capacidade ou incapacidade da razão para um tão grande empreendimento. (KANT, 1980, p.25)

Para Kant "a razão não é constituída apenas por uma dimensão teórica, que busca conhecer (e ultrapassa os limites do conhecimento), mas também por uma 
dimensão prática, que determina seu objeto mediante a ação" (KANT, 1980, p. XVIII). Nesse sentido, a razão criaria um "mundo moral", onde poderiam ser encontrados os fundamentos do agir humano. Em razão dessa questão prática, que tinha como objeto a ação humana, Kant desenvolveu em seguida duas obras fundamentais para o pensamento moderno: a Crítica da Razão Prática e a Fundamentação da Metafísica dos Costumes.

Em meio a esse projeto, em 1784, Kant publica o ensaio Resposta à pergunta: $O$ que é Esclarecimento? em resposta ao pastor Johann Friedrich Zöllner, que havia publicado no famoso periódico Berlinische Monatsschrift um artigo contra a legalização unicamente civil do casamento e a favor do matrimônio sancionado por cerimônia religiosa. No número anterior do jornal, um autor anônimo havia se mostrado favorável à possibilidade de haver um casamento que não precisasse passar pelo ritual religioso, o que motivou Zöllner a escrever tal publicação. Para ele, as conversas em torno da Aufklärung haviam formado uma grande confusão nos corações e mentes dos homens e, por isso, todos deveriam, antes de buscar esclarecer-se, procurar a resposta para "o que é o esclarecimento?", resposta essa que ele dizia não ter encontrado em lugar algum. Essa observação, feita por Zöllner em nota de pé de página, aguçou logo os ânimos dos entusiastas da Aufklärung. Primeiramente, respondeu à pergunta Moses Mendelssohn, no mesmo jornal, no número posterior e em seguida Immanuel Kant ${ }^{16}$ também se propôs a respondê-la.

Kant então escreve de forma objetiva aquilo que defende acerca do assunto: "Esclarecimento é a saída do ser humano de sua menoridade, menoridade na qual ele se inseriu por sua própria culpa" (KANT, 2011, p.24). Baseado em seu sistema filosófico e na certeza de haver entre os homens a inclinação natural ao uso da razão, Kant defendeu que houvesse liberdade para o uso público de tal capacidade, sobretudo entre os eruditos de sua época.

Segundo o autor, o ser humano precisaria, por natureza, de condução alheia durante algum tempo em sua vida. Por esse motivo, alguns seres humanos se tornariam tutores de outros. Contudo, haveria um momento em que essa tutela já não se faria mais necessária, pois o indivíduo já seria capaz de se servir de seu próprio entendimento. Quando ele se recusa a reconhecer e cultivar essa

${ }^{16} C f$. KANT et al. O que é Esclarecimento? Tradução: Paulo Cesar Gil Ferreira; Revisão: Marco Antonio Casanova. - 1, Ed. - Rio de Janeiro: Via Verita, 2011. 
capacidade e continua a se deixar tutelar, assim o faz por preguiça ou covardia. Kant avalia que quando recorremos a um livro, que irá ter um entendimento por nós, a um assistente espiritual, que usa sua consciência em lugar da nossa, a um médico, que nos orientaria sobre o que deveríamos comer, e assim por diante, poupamos um grande esforço: o de pensar por nós mesmos. Só nos seria necessário pagar e então alguém pensaria em nosso lugar.

Esta seria a condição na qual se encontra o ser humano e não somente alguns indivíduos. Para Kant, a sociedade se estrutura de modo a fazer com que o homem não se sirva de seu próprio entendimento e se submeta à condução de outrem. Seria preciso, por isso, ter resolução e coragem para sair de tal situação. Contudo, diferente de uma revolução que poderia talvez "levar a termo a queda do despotismo personalista e da opressão ávida por riqueza ou domínio" (KANT, 2011, p.24), uma verdadeira reforma no pensamento só pode se dar de forma lenta. Caso contrário, novos preconceitos viriam para substituir os velhos com a mesma função de servir de coleira para uma multidão destituída da habilidade de pensar com liberdade.

Desse modo, Kant mostra que o cultivo do pensamento é um processo lento e gradual, que não se alcança por meio de revoluções e que a única coisa que se precisa para que se alcance tal esclarecimento é a liberdade, a possibilidade de se fazer o uso público da razão por toda parte. Somente o uso público da razão seria capaz de promover e concretizar o esclarecimento entre os seres humanos. Contudo, para Kant o que se tem na sociedade é um convite contínuo para que o homem não use sua razão: “Ora, ouço, contudo, clamarem de todos os lados: não raciocine! O oficial diz: não raciocine, exercite-se! O conselheiro de finanças: não raciocine, pague! O clérigo: não raciocine, crê!” (KANT, 2011, p.26). Ele então enaltece Frederico II, ao reconhecer que apenas um único senhor em todo o mundo foi capaz de dizer "raciocinai, tanto quanto quiserdes e sobre o que quiseres; porém, obedecei!" (idem). Frederico II, que acabou por se tornar figura emblemática do despotismo esclarecido, também era conhecido por seus dotes intelectuais e seu interesse por arte e ciências. Apesar de manter um governo autoritário, ficou conhecido por demonstrar uma afinidade com ideais progressistas.

Kant acreditou estar vivendo em uma época de esclarecimento e elogiou o grande feito de Frederico II de não prescrever nada aos seus súditos com relação 
às questões religiosas, dando-lhes total liberdade nesse assunto. Kant considerou que assim Frederico havia libertado o povo, pelo menos por parte do governo, de sua menoridade, deixando que decidissem por sua própria razão os assuntos referentes à fé religiosa.

Sobre o uso público da razão, Kant diz que ele seria aquele uso que o erudito faz diante de um público igualmente letrado. Já o uso privado é o uso que se faz da razão no exercício de um cargo civil específico. Para o filósofo, somente o primeiro uso é capaz de contribuir para o progresso da humanidade. O ser humano, assim, tem em sua vida dois âmbitos de exercício do seu entendimento: o público, no qual ele se insere como parte de uma coletividade organizada, de uma sociedade civil, e o privado, no qual ele é parte de um negócio. Nesse segundo caso, Kant considera que pode ser necessário que se crie uma "unanimidade artificial" (KANT, 2011, p.27). No âmbito privado, portanto, o indivíduo deve atender aos interesses da coletividade e, por isso, deve obedecer. No uso privado de sua razão, ele deve seguir as regras, pois, caso ele não as siga, ele pode obstruir o funcionamento do local em que está atuando.

Dentre os exemplos que Kant apresenta sobre o uso público e o uso privado está o do sacerdote, que, segundo o seu pensamento, deve fazer a pregação aos seus alunos de catecismo seguindo as tradições da igreja a que ele serve. Contudo, como erudito, ele deve ter a vocação de comunicar seus pensamentos a respeito do que ele de forma "bem intencionada" e "meticulosamente comprovada" concluiu estar sendo feito de forma errônea. Ele pode, inclusive, propor sugestões que favoreçam a entidade. Enquanto ensina, no entanto, ele não deve se sentir culpado por não ensinar de acordo como acredita que deveria. Uma vez que ele, como encarregado da Igreja, não pode por conta própria e de forma privada, ensinar como bem lhe convier. Caso os preceitos nos quais acredita forem de encontro com os da religião que ele prega, aí sim, ele deve renunciar.

Este exemplo mostra como Kant busca conciliar o uso do pensamento à obediência, restringindo o local apropriado ao uso livre da razão e as condições desse uso. Esse entendimento sobre a liberdade da razão é oposto ao pensamento bastante recorrente de que algumas regras podem ser quebradas dentro de círculos mais próximos de convivência. Diferente do entendimento comum, o espaço privado é exatamente onde não se deve de modo algum descumprir as regras estabelecidas socialmente. No espaço privado, deve-se seguir as regras, mesmo 
quando se é contrário a estas. O espaço de questionamento e de exposição racional de argumentos é o espaço público. Somente fora dos círculos privados é que se deve propor a alteração de regras mediante a consulta e o julgamento da opinião pública. Essa regra geral se estende para tudo o que é criado mediante acordos comuns dentro da sociedade.

Kant acreditou que a saída da menoridade dos seres humanos não representaria um perigo para os chefes de Estado e que estes deveriam permitir a seus súditos fazer uso público livre da razão. De acordo com o autor, qualquer cidadão deveria poder manifestar publicamente seus pensamentos a respeito inclusive de assuntos relacionados à legislação, propondo uma melhor formulação das mesmas.

(...) a liberdade não representa nem um mínimo de preocupação para a tranquilidade pública e para a unidade da comunidade. Os seres humanos esforçam-se por si mesmos pouco a pouco para se retirarem da barbárie, contanto que não se urda deliberadamente uma artimanha para mantê-los nessa situação. (KANT, 2011, p.34)

Contudo, Kant não deixa de considerar que para garantir tal liberdade de pensamento seria necessário, além de um monarca esclarecido, também um disciplinado exército. Kant acreditou que a liberdade civil caminhava ao lado da liberdade do espírito de um povo e que esta requeria a estrita obediência à ordem. Além disso, quanto mais estivesse garantida a liberdade do pensamento, maior seria a possibilidade de o povo buscar melhores maneiras de se organizar e desenvolver suas capacidades.

Dessa forma, Kant tornou-se um dos grandes defensores da luta entre a razão e os preconceitos que se encontram enraizados na sociedade e que são transmitidos pelos tutores que se apoiam somente na autoridade da tradição. Era objetivo do filósofo que pudéssemos submeter ao julgamento da razão tudo aquilo que nos fosse fornecido pelos costumes de nossa sociedade. Para Kant, essa seria a maneira de nos livrarmos de possíveis erros e enganos que eram passados de geração em geração e colocar a humanidade no caminho do progresso. Kant vislumbrava um momento em que os indivíduos pudessem autonomamente julgar o certo e o errado, não precisando para isso recorrer à autoridade do julgamento de outra pessoa. Essa crença no progresso da razão humana se baseava em outra 
crença: a de haver uma razão universal da qual todos os seres humanos participavam.

De acordo com o que analisamos até aqui, em linhas gerais, o preconceito tal como concebido por Kant nada mais era do que todo aquele conhecimento que era transmitido aos outros homens por seus tutores, que acabavam promovendo uma aceitação passividade que culminava com a incapacidade de pensar por si mesmo. Ele acreditava ser possível por sob a revisão da razão tudo aquilo que a tradição havia passado de uma geração para outra de maneira irrefletida. Agir seguindo os preceitos de uma tradição seria então agir de acordo com os ditames de outrem.

A razão humana funcionaria então como um ponto fora da tradição, à qual o homem poderia recorrer e nela confiar. Subjaz a essa ideia a noção de subjetividade. A ideia é a de que o ser humano possui algo que é acessível somente por meio de uma autorreflexão, de uma estrutura formal e ao mesmo tempo universal de razão. Em grande medida, essa noção ainda é a que serve de fundamento para as ações educativas, uma vez que ela garante que para além dos contextos particulares de vida, subjaz a todos algo que é comum e passível de ser educado: o ser racional.

\section{2 \\ Gadamer e a crítica do "preconceito contra o preconceito"}

Como já vimos anteriormente, Gadamer retoma a ideia de circularidade da compreensão de Heidegger. Contudo, diferente de Heidegger, que privilegiou a questão ontológica, ou seja, que empenhou-se em mostrar como esta é a estrutura fundamental do ser-aí, Gadamer irá mais adiante na busca por demonstrar como é possível, fazendo jus à historicidade da compreensão, obter conhecimento verdadeiro a partir dela. Ele se ocupa assim do fenômeno da compreensão tanto num sentido ontológico, como num sentido epistemológico, como percebe Schmidt (2017, p.146).

Nossa compreensão é o que responde pelo nosso estar em um mundo, e Gadamer, assim como Heidegger, viu a história e a linguagem como sendo a base na qual ela se estrutura. Compreender é estar inserido em um mundo de tal maneira que ele de início e na maioria das vezes não precisa ser tematizado por nós. Guiamo-nos em nosso mundo de forma compreensiva e por isso a 
compreensão é o ponto de partida de toda e qualquer interpretação. Ela é um conhecimento que guardamos de forma implícita, que adquirimos nas práticas cotidianas, sem que precisemos fazer sobre elas um questionamento explícito.

Para Gadamer, o fato de Heidegger ter baseado na temporalidade do ser-aí a estrutura circular da compreensão não deve ter como consequência a aplicação de uma nova teoria a respeito do ser humano, que teria a intenção de mudar o modo como ele atua no mundo. Antes disso, ela teria aberto a possibilidade de que "a autocompreensão da compreensão exercida constantemente fosse corrigida e depurada de adaptações inadequadas" (GADAMER, 1997, p.400), que se daria em meio ao próprio compreender.

A circularidade da compreensão abre, na visão de Gadamer, a possibilidade de se chegar a um conhecimento mais originário sobre as coisas na interpretação sobre elas. É importante observar que essa busca por um conhecimento mais originário requer um esforço por parte daquele que interpreta, o esforço de manter-se orientado pela coisa ela mesma que, como vimos, também tem o seu sentido fundado historicamente. Ele descreve esse esforço a partir da seguinte citação que faz de Heidegger:

Quando a interpretação compreender que sua tarefa primeira, constante e última permanece sendo a de não receber de antemão, por meio de uma "feliz ideia" ou por meio de conceitos populares, nem a posição prévia, nem a visão prévia, nem a concepção prévia (Vorhabe, Vorsicht, Vorgriff), mas assegurar o tema científico na elaboração desses conceitos a partir da coisa ela mesma. (HEIDEGGER apud GADAMER, 1997, p. 401)

Nesse ponto, é possível ver, a princípio, uma aproximação com o que já foi apresentado nesse trabalho a respeito do que falou Kant sobre a tradição. Para Kant, o uso público da razão seria esse exercício de não receber de modo passivo o que nos é passado por aqueles que assumem o papel de tutores da humanidade. A diferença entre os dois pensamentos, contudo, já aparece quando observamos o modo como ambos conceberam o ser humano e como cada um funda a possibilidade de se chegar ao conhecimento. Se por um lado, Kant recorrerá a ideia de haver uma razão universal a priori, capaz de servir como instância reguladora, que por sua universalidade e atemporalidade poderia colocar sob suas vistas tudo o que se pode conhecer, a filosofia hermenêutica de Gadamer procurará demonstrar a impossibilidade de tal pretensão. Com isso, ela fundará a possibilidade de todo conhecimento na própria condição histórica do ser humano. 
Para Gadamer, todo conhecimento, inclusive o próprio conhecimento dito racional, não pode ignorar a sua historicidade. A noção de racionalidade é ela mesma cunhada em um contexto histórico que é bastante específico, por isso, ela não pode se colocar como um ponto arquimediano que, por estar fora do mundo, serviria de apoio para mover este mesmo mundo.

(...) a ideia de uma razão absoluta não é uma possibilidade da humanidade histórica. Para nós a razão somente existe como real e histórica, isto significa simplesmente: a razão não é dona de si mesma, pois está sempre referida ao dado no qual se exerce. (GADAMER, 1997, p.415)

O esforço de manter-se orientado pela coisa e evitar a arbitrariedade da ocorrência de "felizes ideias" tem origem na leitura de textos com sentido, que, por sua vez tratam das coisas de um modo geral. Por isso, a tarefa de interpretar pode ser estendida para os contextos de vida, na medida em que ela não se restringe à leitura de textos escritos. Ao compreender o mundo, interpretamos situações, objetos, falas, ações, por isto, este é um movimento constante de todo o compreender, que busca tornar familiar aquilo que se apresenta diante de nós em diferentes ocasiões.

O que ocorre com um intérprete diante de um texto, segundo Gadamer, é um “projetar" (GADAMER, 1997, p.402). Esse projetar se refere a uma tomada de direção com relação ao todo do texto. Projetar significa ter que se apropriar do texto interpretado a partir de um investimento de sentido que ultrapassa o texto. Para o filósofo, “tão logo apareça um primeiro sentido no texto, o intérprete prelineia um sentido do todo" e isso só acontece porque "quem lê o texto lê a partir de determinadas expectativas e na perspectiva de um sentido determinado" (idem). Esse projetar e reprojetar colocam em um constante movimento nossos preconceitos e os substitui por outros mais adequados. Por isso, como observa Gadamer:

Quem procura compreender está exposto a erros de opiniões prévias, as quais não se confirmam nas próprias coisas. Elaborar os projetos corretos e adequados às coisas, que como projetos são antecipações que apenas devem ser confirmadas "nas coisas", tal é a tarefa constante da compreensão. (GADAMER, 1997, p.402)

Assim, a objetividade daquilo que conhecemos está na possibilidade de nos mantermos orientados pelas próprias coisas, abertos ao que elas nos dizem e atentos à possibilidade de estarmos sendo ludibriados por concepções arbitrárias. 
Aqui vemos claramente que Gadamer faz uma distinção entre os "maus" preconceitos ou os preconceitos arbitrários e os "bons" preconceitos, que são adequados à coisa. Ou seja, o que nos permite alcançar um conhecimento sobre algo é estarmos dispostos a abrirmos mão desses preconceitos arbitrários em favor de outros mais legítimos. Ainda nesse caso, ele não prega a mera abolição dos preconceitos em favor de uma subjetividade neutra, ou purificada pela crítica, capaz de pôr os próprios preconceitos sob revisão. Tampouco faz uma apologia de todo e qualquer preconceito, uma vez que distingue preconceitos arbitrários de preconceitos legítimos. Para a hermenêutica gadameriana, o que há é uma contraposição de preconceitos, o que já revela a historicidade de todo compreender. Como caracteriza Schmidt:

Em qualquer momento particular, nossos preconceitos, como nossas estruturas de compreensão herdadas, incluem tudo que sabemos consciente ou inconscientemente. Eles incluem o significado de palavras, nossas preferências, os fatos que aceitamos, nossos valores, e juízos estéticos, nossos juízos sobre a natureza humana e o divino e assim por diante. Na maior parte do tempo, não percebemos a maioria de nossos preconceitos, apesar de podermos trazer alguns deles para a percepção consciente. (SCHMIDT, 2017, p. 147)

O problema então passa a ser entendido como "achar a saída do cabo de forças das opiniões prévias" (GADAMER, 1997, p.404). As opiniões prévias, que determinam minha compreensão sobre algo, na maioria das vezes não estão claras para mim. Caso elas sejam arbitrárias e promovam mal-entendidos, como seria possível eu perceber? Diante disso, Gadamer responde que aquilo que o outro diz, num diálogo ou através de um texto, dificilmente encaixa-se sem rupturas nas minhas próprias opiniões e expectativas. Desse modo, seria impossível manter por muito tempo uma compreensão incorreta sobre algo sem que esta destrua o sentido do todo, nem "manter, às cegas, as próprias opiniões prévias sobre as coisas quando se compreende a opinião do outro" (idem). Assim, no contato com o que diz o outro, temos contato com as nossas opiniões prévias, ou seja, com nossos próprios preconceitos. Contudo, para que compreendamos o que o outro diz, sem impormos ao que é dito aquilo que nós mesmos pensamos, não é necessário colocar de lado nossas opiniões. De acordo com Gadamer:

Quando se ouve alguém ou quando se empreende uma leitura, não é necessário que se esqueçam todas as opiniões prévias sobre seu conteúdo e todas as opiniões próprias. $\mathrm{O}$ que se exige é simplesmente a abertura à opinião do outro ou à do texto. Mas essa abertura já inclui sempre que se ponha a opinião do outro em 
alguma relação com o conjunto das opiniões próprias, ou que a gente se ponha em certa relação com elas. (GADAMER, 1997, p.404)

Quando existe essa "abertura" somos capazes de ouvir o que é exposto como uma opinião que é a de outro e não a nossa e que devemos tomar conhecimento, mas não precisamos compartilhar. Essa abertura não é algo que necessariamente ocorrerá; ela exige um esforço daquele que compreende em não "se entregar, já desde o início, à casualidade de suas próprias opiniões prévias" (idem) ignorando obstinadamente o que diz o outro. Gadamer acredita que isso exige uma "consciência formada hermeneuticamente", que se mostre receptiva, desde o início, à alteridade do outro, o que de modo algum significa neutralidade ou suspensão da própria perspectiva diante do outro, mas a capacidade de distinguir-se do outro e assim obter "a possibilidade de confrontar sua verdade com as próprias opiniões prévias" (idem, p. 405).

Quando nos abrimos no contato com o outro, e deixamos que ele fale sem impor ao que ele diz um preconceito arbitrário, colocamos em relação aquilo que concebemos previamente e aquilo que nos diz o outro. Desse modo, quando há essa abertura diante do outro, colocamo-nos diante de nossos próprios preconceitos. Somente assim, somos capazes então de renunciarmos a preconceitos arbitrários, reconhecendo preconceitos mais legítimos. Dessa forma, para a hermenêutica:

Uma compreensão guiada por uma consciência metódica procurará não simplesmente realizar suas antecipações, mas antes, torná-las conscientes para poder controlá-las e ganhar assim uma compreensão correta a partir das próprias coisas. (GADAMER, 1997, p.406).

Podemos, mais uma vez, contudo colocar aqui a seguinte questão: o que diferencia tal consciência metódica da subjetividade racional da Aufklärung? Já de início Gadamer chama a atenção para o fato de a consciência metódica não ser um "assegurar-se a si mesmo contra a tradição", mas, pelo contrário, manter-se afastado de tudo aquilo que nos impeça de ouvi-la, a partir dela mesma. "São os preconceitos não percebidos os que, com seu domínio, nos tornam surdos para a coisa de que nos fala a tradição." (idem). Para Gadamer, diferente de Descartes e de Hegel, que com as ideias de consciência e espírito ainda interpretavam o ser como ser presente e atual, Kant descreveu a autocompreensão, em suas premissas ontológicas sobre o conceito de subjetividade, como uma posição prévia de onde 
seria possível compreender toda a tradição. Diferente disso, Gadamer afirma que somente uma consciência histórica é capaz de compreender o que nos diz a tradição. E que "somente um tal reconhecimento do caráter essencialmente preconceituoso de toda compreensão leva o problema hermenêutico a sua real agudeza" (idem), o que significa dizer que o ponto a partir do qual compreendemos uma tradição são os próprios preconceitos que por ela nos são trazidos. Como já falamos anteriormente, de maneira introdutória, é dessa forma que Gadamer chega à conclusão de que é justamente no contexto da Aufklärung que o preconceito ganha seu caráter eminentemente negativo.

Pois há realmente um preconceito do Aufklärung que suporta e determina sua essência: esse preconceito básico do Aufklärung é o preconceito contra os preconceitos, enquanto tais, e, com isso, a despotenciação da tradição. (GADAMER, 1997, p.407).

Dessa forma, herdamos da tradição moderna o preconceito contra o preconceito. Este preconceito nos levou a considerar que apenas aquilo que é arbitrário e negativo é de fato um preconceito e esse pensamento limitou, em grande medida, uma autocompreensão da compreensão. Como avalia Gadamer: "preconceito não significa, pois, de modo algum, falso juízo, pois está em seu conceito que ele possa ser valorizado positivamente ou negativamente" (idem). Mesmo quando se avalia o parentesco com a palavra latina praejudicium, Gadamer observa que junto ao matiz negativo existe um matiz positivo, uma vez que pode haver "prejugés légitimes". Contudo, no uso corrente da língua, esse sentido positivo se perdeu, restando apensa o sentido negativo daquilo que seria um “juízo não fundamentado".

Uma análise da história do conceito mostra que é somente no Aulfklarung que o conceito do preconceito recebeu o matiz negativo que agora possui. Em si mesmo, "preconceito" (Vorurteil) quer dizer um juízo (Urteil) que se forma antes da prova definitiva de todos os momentos determinantes segundo a coisa. No procedimento júris-prudencial um preconceito é uma pré-decisão jurídica, antes de ser baixada uma sentença definitiva. Para aquele que participa da disputa judicial, um preconceito desse tipo representa evidentemente uma redução de suas chances. Por isso, préjudice, em francês, tal como praejudicium, significa também prejuízo, desvantagem, dano. Não obstante, essa negatividade é apenas secundária. É justamente na validez positiva, no valor prejudicial de uma pré-decisão, tal qual o de qualquer precedente, que se apoia a consequência negativa. (GADAMER, 1997, p. 407) 
Um juízo, para ter sua legitimidade garantida precisaria, então, de uma fundamentação, de uma certeza que se baseava na possibilidade de uma verificação metódica, seguindo a "dúvida cartesiana de não aceitar por certo nada sobre o que exista alguma dúvida" (GADAMER, 1997, p.408). O que tal procedimento ignorou é que atuam, nessa verificação metódica, outros preconceitos e não uma razão pura, livre de conteúdos historicamente construídos.

Um exemplo sobre o modo como operam nossos preconceitos, pode ser verificado então no próprio uso da palavra preconceito. Como podemos observar a partir de Schmidt, ao ouvir esta palavra, os "preconceitos em relação à sintaxe e semântica do português ${ }^{17}$ estavam todos operando num nível que você não percebia" (2017, p.147). A conotação negativa da palavra foi provavelmente a que guiou a compreensão num primeiro momento. Em seguida, uma nova possibilidade abriu-se sobre o mesmo termo e, talvez, uma nova compreensão tenha se instaurado, a de que as nossas próprias estruturas prévias de interpretação, que constituem nossa compreensão, são preconceitos. Assim, podemos caminhar neste trabalho com o novo preconceito em relação ao significado da palavra "preconceito", pelo menos enquanto estivermos nos guiando pela hermenêutica de Gadamer.

\subsection{1.}

\section{Os preconceitos de autoridade e os preconceitos por precipitação}

Ao avaliar como a Modernidade compreendeu os preconceitos, Gadamer propõe dividi-los de duas maneiras: o preconceito fundado na autoridade e o preconceito por precipitação. Para Gadamer, seguindo a teoria desenvolvida na Aufklärung, podemos distinguir duas modalidades de preconceitos, aqueles gerados pelo respeito que se tem a outro indivíduo, ou seja, baseados em sua autoridade, e, de outro lado, aqueles gerados por precipitação, ou seja, por antecipações que têm origem em nós mesmos. Ambos os preconceitos poderiam nos induzir a erros. Diante disso, Kant propôs como saída o uso livre e, ao mesmo tempo, metódico da razão.

Ainda no texto Resposta à pergunta: $O$ que é Esclarecimento?, Kant prioriza o combate ao dogmatismo religioso da tradição cristã, que tem como

\footnotetext{
${ }^{17}$ Considerando que Schmidt escreveu o livro em inglês, houve certamente aqui uma alteração do tradutor.
} 
principal fonte de verdades a Sagrada Escritura. Kant desejava garantir que se pudesse, no uso público da razão, contestar os símbolos religiosos e a pretensão de verdade que estes carregavam. A intenção de Kant não era combater a igreja, mas sim o dogmatismo religioso. Para ele, quando um clérigo era impedido de expressar publicamente alguma contestação com relação ao que lhe foi pedido que ensinasse aos seus fiéis, o próprio conhecimento sobre os símbolos religiosos estaria em perigo, uma vez que ele estaria sendo privado de livrar-se de interpretações equivocadas. Desse modo, a autoridade da igreja se tornava uma fonte de enganos. Para que a humanidade caminhasse para seu progresso, não se poderia aceitar, portanto, que os preconceitos fossem simplesmente transmitidos pela tradição, eles deveriam estar sujeitos à análise metódica da razão, sobretudo, os preconceitos religiosos, uma vez que, como percebia Kant, não existia entre as autoridades "nenhum interesse em praticar a tutela sobre os seus súditos com relação às artes e às ciências" (KANT, 2011, p.35). Com isso, o lema fundamental da Aufklärung tornou-se: faça uso de seu próprio entendimento, saia da menoridade e faça uso autônomo de sua razão. Não aceite como verdade os preconceitos fornecidos por seus tutores. Como afirma Gadamer:

(...) [A] tendência geral do Aufklärung é não deixar valer autoridade alguma e decidir tudo diante do tribunal da razão. Assim, a tradição escrita, a Sagrada Escritura, como qualquer outra informação histórica, não pode valer por si mesma. Antes, a possibilidade de que a tradição seja verdade depende da credibilidade que a razão lhe concede. A fonte última de toda a autoridade já não é a tradição, mas a razão. O que está escrito não precisa ser verdade. Nós podemos sabê-lo melhor. (GADAMER, 1997, p.410)

Assim, a Modernidade tornou a tradição objeto de investigação histórica, e passou a investigá-la tal como faziam as ciências da natureza. Os preconceitos verdadeiros precisavam ser justificados de forma racional, mesmo que esta tarefa não pudesse ser realizada completamente. É importante ressaltar que Kant não propunha substituir o dogmatismo religioso pela profissão do ateísmo. A Aufklärung alemã considerou que haveria também os preconceitos religiosos verdadeiros. Como observa Gadamer, para a Aufklärung "dado que a razão humana seria demasiado débil para passar sem preconceitos, teria sido uma sorte se tivesse sido educada nos preconceitos verdadeiros" (idem). 
A marcha moderna contra o misticismo e pelo "progressivo 'desencantamento' do mundo" (GADAMER, 1997, p.411) se faz sentir em toda a sua plenitude em nosso mundo. Até mesmo nos assuntos da fé, o que é "cientificamente comprovado" tem o caráter de verdade. Mesmo a comprovação de milagres na religião cristã passa pelo crivo da ciência e, inclusive, cabe aos especialistas em ciência da religião, filologia, história, teologia etc. apontar as inconsistências e coerências históricas nos textos bíblicos. A relação com a coisa tem por anteparo o método e sua pretensa neutralidade, garantida pelo rigor racional. A autoridade dos religiosos foi aos poucos substituída pela autoridade da avaliação racional das ciências que tem como objeto de pesquisa a religião. Desse modo entramos em um "estágio moderno de fé nas ciências" (GADAMER, 1997, p.413).

Diante disso, Gadamer evidentemente não irá propor uma desracionalização do mundo, ou sua descientificização. Essa investida só seria possível se desconsiderássemos nossa própria condição. Como seres históricos, o modo de ser moderno não é apenas uma prerrogativa, ele nos constitui e atua na nossa compreensão de modo determinante. Na verdade, a pergunta de Gadamer é muito mais a seguinte: "achar-se imerso em tradições significará realmente em primeiro plano estar submetido a preconceitos e limitado na própria liberdade?" (GADAMER, 1997, p.415) Ou esta: "Não é certo, antes, que toda existência humana, mesmo a mais livre, está limitada e condicionada de muitas maneiras?" (idem). Segundo o autor, somente a elucidação dessas questões nos levará a uma adequada compreensão do papel da finitude humana e de sua consciência historicamente condicionada. Apenas a partir de então será possível estabelecer uma análise hermenêutica da história. Observando-a pelo do ponto de vista de quem, justamente por estar dentro dela, compreende e compartilha aquilo que a tradição conseguiu transmitir e, com isso, consegue ter sobre essa mesma história, não uma interpretação absolutamente neutra, mas a mais autêntica e próxima possível. Para Gadamer:

Na realidade, não é a história que pertence a nós, mas nós é que a ela pertencemos. Muito antes de que nós compreendamos a nós mesmos na reflexão, já estamos nos compreendendo de uma maneira autoevidente na família, na sociedade e no Estado em que vivemos. A lente da subjetividade é um espelho deformante. (GADAMER, 1997, p.416) 
O que determina o nosso agir e o modo como nos relacionamos uns com os outros engloba muito mais do que os nossos juízos ou aquilo que somos capazes de expressar conscientemente. Nosso agir é atravessado pelos preconceitos que herdamos de nossa tradição e dos quais não temos nem mesmo plena consciência. Por mais que desejássemos nos manter em um estado de alerta e vigiássemos nossa forma de pensar e agir, atuariam no julgamento desse pensar e agir outros preconceitos e assim sucessivamente. Como define Gadamer: "a autorreflexão do indivíduo não é mais que uma centelha na corrente cerrada da vida histórica" (idem). Desse modo, "os preconceitos de um indivíduo são, muito mais que seus juízos, a realidade histórica do seu ser" (idem). Essa "realidade" de que fala Gadamer é impossível de ser completamente abarcada pela cognição.

Diante de tal afirmação podemos colocar a seguinte questão: o que dizer a respeito daqueles preconceitos que já se mostraram problemáticos e arbitrários, de modo a obstaculizarem nossos esforços interpretativos? Como é possível entendermos a permanência de tais preconceitos dentro de uma tradição? Retornaremos a estas questões mais adiante, quando tivermos mais elementos para respondê-las de uma perspectiva hermenêutica. Agora, contudo, o que podemos observar é que interpretações ocorrem para além de nossa intenção racional. Quando Gadamer nos diz que a tradição é mais do que os nossos juízos, isso significa dizer que, por mais que julguemos de determinada maneira, é na nossa compreensão prévia que a tradição se manifesta de forma completa.

Podemos aqui citar um exemplo do que ocorre dentro das instituições de ensino. Um dilema que muitos professores enfrentam no presente momento, em que a escola é convidada a repensar suas práticas, é sobre em que medida se deve questionar o modelo tradicional de ensino sem que isso signifique ter de abandoná-lo e, dessa forma, colocar em questão aquilo que afinal se reconhece pelo conceito mais difuso de educação. Embora o modelo tradicional já tenha recebido inúmeras críticas e, por isso mesmo, ele não seja passível de uma justificação insuspeita, ele ainda é largamente empregado nas escolas, como observa Brighenti et al (2015). O modelo das aulas expositivas, com bastante conteúdo teórico e exercícios de memorização, no interior do qual existe pouca ou nenhuma possibilidade de expressão criativa por parte dos alunos, está de tal modo cristalizado em nossa compreensão prévia que, por mais que exista uma forte crítica contrária, muitos professores recorrem predominantemente a ele com 
diversas justificativas. Uma dentre essas justificativas é a de que este seria o único modelo possível "para dar várias aulas seguidas em salas superlotadas" (VELASCO, 2016 p.19). Contudo, o que vemos é que mesmo as escolas que buscam escapar do ensino tradicional, reduzindo seu número de alunos por sala, oferecendo cursos de formação continuada para seu corpo docente e diferentes recursos materiais, ainda enfrentam a resistência de diversos professores em ensinar de um modo diferente do qual eles mesmos foram ensinados na escola. $\mathrm{O}$ que percebemos com isso é que a tradição das aulas expositivas permanece, porque ela é reafirmada na prática pelo professor que a ministra. Embora possam coexistir no mesmo corpo docente professores que adotem modelos diferentes de ensino, ainda existem aqueles que acreditam estar fazendo o melhor pelos seus alunos atuando de acordo com um modelo "mais tradicional". Para ilustrar tal situação, cito aqui a fala de Velasco. Um professor que, em sua dissertação de mestrado, intitulada Histórias de Cuspe e Giz, decidiu narrar algumas histórias que vivenciou dentro de uma escola pública da Baixada Fluminense ao longo de quase três décadas (1985-2015). Sobre a escolha do título, Velasco afirma:

\begin{abstract}
Ainda me resta um esclarecimento importante. Fui instado pela amada professora Rita Ribes a explicar o porquê da utilização desse título em minha dissertação uma expressão muito usada para insultar, injuriar e ofender escolas e professores que se utilizam apenas de sua voz e do quadro negro para lecionar. Contudo, durante a maior parte do meu tempo de magistério, exercido em escolas públicas estaduais, na baixada fluminense, nós professores apenas tivemos como instrumento de trabalho mimeógrafo, giz, quadro de giz e, lógico, nossas vozes. Uso a expressão "histórias de cuspe e giz" para dar nome a este trabalho, não intencionando insinuar que as histórias aqui contadas não tenham importância, sejam ruins ou mal elaboradas. Na verdade, meu objetivo é apresentar histórias e fatos que foram recolhidos durante o trabalho e a vivência dentro da escola e na sala de aula entre livros, pó de giz, quadro de giz, folhas mimeografadas e muita saliva para dar várias aulas seguidas em salas superlotadas. Essa expressão é uma forma de dizer que essas narrativas e reflexões sobre uma determinada e especial escola são reais, foram vividas, sentidas, percebidas e sofridas durante o processo ensino/aprendizagem na relação eu e o outro, no diálogo, na responsividade e no ato responsável. Ela é uma expressão legitimamente escolar, concreta e faz parte da tradição dentro dessa instituição. (VELASCO, 2016 p.19)
\end{abstract}

Como observa Schmidt (2017, p.149), Gadamer rejeita a antítese iluminista entre razão e tradição para afirmar que uma tradição "precisa ser afirmada, assumida e cultivada. A tradição é essencialmente conservação (...). No entanto, a conservação é um ato da razão, ainda que caracterizado pelo fato de não atrair a atenção sobre si." (GADAMER, 1997, p.422). Assim, “o fato de alguma coisa ter 
sobrevivido numa tradição implica que ela provavelmente foi considerada digna por aqueles que a acolheram" (SCHMIDT, 2017, p.149). O que fica claro na fala do professor Velasco é que a escola sentida e vivida é a imagem do professor que dá aulas expositivas usando como instrumentos sua voz, o giz e a lousa de giz que é ainda a expressão mais concreta na tradição escolar. Para Velasco, mais do que um modelo de escola, é uma expressão legitimamente escolar. Por mais que a posição do autor possa ser contestada, não podemos negar que ela conta com a concordância de uma grande parcela de educadores.

\section{3.}

\section{A reabilitação da autoridade e da tradição na hermenêutica}

Como vimos acima, seria possível dividir os preconceitos em preconceitos de autoridade e preconceitos por precipitação. O primeiro diz respeito ao modo como a autoridade do outro, seja de um livro, um professor, um líder religioso ou um médico, por exemplo, levar-nos-ia a tomar algo por certo sem que fizéssemos uso de nossa própria razão. O segundo seria o juízo precipitado sobre as coisas, causado pelo mau uso da razão. Neste segundo, encontra-se a "premissa fundamental da Aufklärung, segundo a qual um uso metódico e disciplinado da razão é suficiente para nos proteger de qualquer erro. A ideia cartesiana de método", como avalia Gadamer (1997, p. 416).

O que ocorre nesses dois casos seria um "preconceito a favor do novo" (GADAMER, 1997, p.416), que por acreditar numa autoconstrução absoluta da razão, não compreende que já sempre nos dirigimos às coisas orientados por uma compreensão prévia que nós já temos delas, ou seja, elas só aparecem para nós como um objeto de conhecimento porque nós já as compreendemos, já participamos do sentido que tais coisas têm em nossa tradição. A ideia de haver uma razão neutra é, na verdade, um preconceito problemático, pois ela ignora a si mesma como um preconceito que veio a ser historicamente. Diante disso, Gadamer considera que só podemos fazer justiça ao modo de ser finito e histórico do ser humano se levarmos a cabo uma drástica reabilitação do conceito de tradição e se reconhecermos que existem nela preconceitos legítimos que podem ser produtivos para o conhecimento. Assim, a primeira tarefa de Gadamer está em mostrar como a autoridade pode ser reconhecida como uma fonte legítima de 
saber e que o reconhecimento de uma autoridade é também um ato da razão de quem a reconhece.

De acordo com Gadamer, a difamação promovida pela Aufklärung contra toda autoridade levou "também a uma grave deformação do próprio conceito de autoridade" (Gadamer, 1997, p.419), que se converteu "simplesmente no contrário de razão e liberdade, no conceito de obediência cega" (idem). A obediência a uma autoridade passou a também ser confundida com a crítica ao autoritarismo, no qual pelo uso da força, como no caso do abuso de poder, poder-se-ia obrigar o outro a fazer uma determinada coisa de modo submisso e sem questionamento. Gadamer contesta:

Todavia, não é isso a essência da autoridade. Na verdade, a autoridade é, em primeiro lugar um atributo de pessoas. Mas a autoridade das pessoas não tem seu fundamento último num ato de submissão e de abdicação da razão, mas num ato de reconhecimento e de conhecimento: reconhece-se que o outro está acima de nós em juízo e perspectiva e que, por consequência, seu juízo precede, ou seja, tem primazia em relação ao nosso próprio. (GADAMER, 1997, p.419)

Gadamer ainda ressalta que "a autoridade não se outorga, adquire-se, e tem de ser adquirida se a ela se quer apelar". Desse modo ela também não pode ser imposta sobre o outro, uma vez que ela "repousa sobre o reconhecimento e, portanto, sobre uma ação da própria razão que, tornando-se consciente de seus próprios limites, atribui a outro uma perspectiva mais acertada" (idem). Desse modo, alguém só vem a ser uma autoridade quando recebe o reconhecimento do outro, que o legitima enquanto tal em uma determinada situação. Quando reconhecemos a legitimidade de uma autoridade, damos a ela a autorização para nos dizer algo ou para contribuir conosco em algo que precisamos realizar. Qualquer coisa que fuja a esse princípio do reconhecimento não seria, portanto, uma autoridade de fato.

Acerca do que foi exposto, Schmidt observa que "nós podemos obedecer cegamente alguém que tenha mais poder; entretanto, isto não é um reconhecimento de autoridade, apenas de poder". (SCHMIDT, 2017, p.148). Desse modo, quando recorremos, por exemplo, a um médico e seguimos a receita que ele nos passa, não o fazemos por obediência cega. Muito pelo contrário, mesmo uma pessoa que tenha pouco conhecimento sobre a própria saúde, diante da mínima desconfiança sobre a autoridade do médico, ela pode optar por não seguir a receita prescrita por ele. Essa desconfiança pode levar esta pessoa a 
buscar outro médico, ou seja, outro profissional que detenha determinado conhecimento que foi publicamente reconhecido quando ele recebeu a diplomação e a licença para atuar como médico.

O que foi exposto acima também ocorre de formar parecida em sala de aula. O professor, para ter licença para ministrar suas aulas, além da autoridade concedida institucionalmente, precisa ter essa autoridade reconhecida a cada momento. Ele precisará provar a cada vez que é uma autoridade em determinado assunto, que possui conhecimentos sobre determinada matéria. Esse reconhecimento respeita uma série de etapas, ele se dá primeiro quando uma pessoa se forma oficialmente como professor ou professora, e, da mesma forma, quando essa pessoa é selecionada para atuar em uma determinada instituição de ensino. Por fim, como dissemos, ele ainda precisará ter sua autoridade reconhecida pelos estudantes, pais e por seus próprios pares. Isso indica que sua autoridade não repousa tão simplesmente no exercício do cargo que ocupa, mas também no modo como ele próprio justifica sua competência para exercê-lo. Um professor está sempre às voltas com a necessidade de comprovar sua competência, de modo que é acima de tudo neste sentido que precisamos conceber sua autoridade. Gadamer nos alerta para o perigo da ausência de rigor que nos leva a esvaziar o conceito de autoridade, o que, por conseguinte, levaria-nos a enxergar o professor pura e simplesmente como um opressor. Contudo, não é possível negar que, assim como nos diz Schmidt, existem situações em que o poder pode ser confundido com a autoridade. O professor está em posição de avaliar o aluno, estabelecer determinadas regras, observar o seu cumprimento, por isso, por mais que busque tomar decisões em conjunto com os alunos e tente distribuir um pouco mais este poder, ele ainda detém o controle majoritário sobre o que será decidido. Esse poder decisório, contudo, não deve ser confundido com a questão da sua autoridade como professor.

É interessante observar como o reconhecimento da autoridade também implica na possibilidade de abertura ou não ao que o outro nos diz, o que veremos mais adiante quando tratarmos do diálogo. O que já podemos considerar por ora é que até mesmo a Aufklärung, que almejava colocar diante do tribunal da razão toda forma de autoridade, precisou recorrer já de início à figura do mestre como uma autoridade legítima. Por mais que ela reconheça essa autoridade por meio de 
fins que possam ser justificados racionalmente, ela reafirma a tradição que nos impõe a tarefa de educarmos uns aos outros.

O homem não pode se tornar um verdadeiro homem senão pela educação. Ele é aquilo que a educação dele faz. Note-se que ele só pode receber tal educação de outros homens, os quais a receberam igualmente de outros. Portanto, a falta de disciplina e de instrução em certos homens os torna mestres muito ruins de seus educandos. Se um ser de natureza superior tomasse cuidado da nossa educação, ver-se-ia, então, o que poderíamos nos tornar. (KANT, 2006, p.15)

Desse modo, quando Kant se vê diante da necessidade de recorrer à educação o mais cedo possível, percebemos que, já de partida, ele se compromete com uma autoridade que não poderia por princípio ser contestada, sob pena de levar toda a humanidade a enormes perdas. Para Gadamer, contudo, a própria existência do mestre é fruto de uma herança histórica que foi consagrada pela nossa tradição. Podemos até considerar que a figura do mestre possui uma autoridade que se tornou anônima, o que faz com que, antes mesmo de nos questionarmos sobre a sua necessidade, e até mesmo a respeito dos fundamentos de sua existência, já a incorporamos e a aceitamos como legítima devido à tradição.

(...) mesmo no caso em que, na educação, a "tutela" perde a sua função com o amadurecimento da maioridade, momento em que as próprias perspectivas e decisões assumem finalmente a posição que detinha a autoridade do educador, esta chegada da maturidade vital-histórica não implica, de modo algum, que nos tornemos senhores de nós mesmos no sentido de nos havermos libertado de toda herança histórica e de toda tradição. (GADAMER, 1997, p. 421)

A chegada à maioridade não nos outorga uma autonomia com relação à tradição. Ela não significa, de modo algum, que deixamos de ser condicionados em grande medida por nossa inserção histórica, passando a ter a nossa razão como única fonte de autoridade. Muito pelo contrário, a habilidade de nos guiarmos em nosso mundo, de fazermos uso correto de nossas antecipações e a própria possibilidade de questioná-las requer de nós uma familiaridade com nossas tradições e a participação em seu sentido. Até mesmo nas investigações históricas, Gadamer entende que o "efeito da tradição que sobrevive, e o efeito da investigação histórica formam uma unidade de efeito, cuja análise só poderia encontrar uma trama de efeitos recíprocos." (GADAMER, 1997, p.424). O objeto de interesse na investigação histórica e o interesse do próprio investigador em 
voltar-se para a tradição é motivado pelo "respectivo presente e seus interesses" (ibid, p.427). Assim, a investigação histórica tem como solo que a sustenta "o movimento histórico em que se encontra a própria vida" (idem). Nesse movimento, aquilo que pareceu relevante em um determinado momento, pode mostrar-se completamente sem importância em outro. E assim, como avalia Schmidt, da mesma forma "como uma pessoa pode perder sua autoridade, um texto pode perder seu estatuto de clássico" (SCHMIDT, 2017, p.149). O que significa que ele pode tanto deixar de ser objeto de interesse, como ele pode revelar-se equivocado sobre algo. E isso se dá porque na nossa compreensão, passado e presente são mediados constantemente e o que é transmitido pela tradição não se conserva sem rupturas.

\section{4 . \\ Distância temporal e história efeitual}

Partíamos então do fato de que uma situação hermenêutica está determinada pelos preconceitos que trazemos conosco. Estes formam assim o horizonte de um presente, pois representam aquilo mais além do qual já não se consegue ver. No entanto, importa que nos mantenhamos longe do erro de que o que determina e limita o horizonte do presente é um acervo fixo de opiniões e valorações, e que face a isso a alteridade do passado se destaca como um fundamento sólido. (GADAMER, 1997, p.457)

$\mathrm{Na}$ passagem acima, Gadamer fala de uma situação hermenêutica determinada pelos preconceitos que trazemos conosco. Essa situação hermenêutica nada mais é do que o momento presente em que nos encontramos, ou seja, em que nos situamos historicamente. Em outras palavras, ela se constitui em um campo de visão que encerra tudo aquilo que pretendemos e podemos compreender de algum modo. Contudo, Gadamer nos diz que seria um erro pensar que essa situação hermenêutica fosse "um acervo fixo de opiniões e valorações" que se fundamentariam na alteridade absoluta de um passado também fixo. Isso porque o "horizonte do presente está em um processo constante de formação" (idem) que coloca em movimento a todo instante os preconceitos que herdamos de nossa tradição. Temos aqui algo decisivo, pois, se o "horizonte do presente está em um processo constante de formação", também o está o horizonte do passado e o do futuro. 
Como já falamos anteriormente, para Gadamer, a antecipação de sentido quando se busca interpretar ou conhecer algo não é um "ato da subjetividade" (1997, p. 439). O que nos possibilita tais antecipações é o fato de nos encontrarmos já sempre vinculados a uma tradição. Essa nossa relação, porém, está em um contínuo processo que vai se instaurando na medida em que participamos do acontecer dessa tradição. Esse processo nos é revelado a partir de um entendimento presente acerca daquilo que veio a ser, o que se torna possível com o que Gadamer nomeou como "distância temporal”.

Diferentemente do que se possa imaginar, a distância temporal não é um obstáculo a ser superado. Uma vez que o tempo não é "um abismo a ser transposto porque divide e distancia, mas é, na verdade, o fundamento que sustenta o acontecer, onde a atualidade finca suas raízes." (GADAMER, 1997, p. 445). A distância temporal, muito pelo contrário, enriquece de possibilidades o próprio compreender. Por isso, Gadamer entende como uma ingenuidade do historicismo pressupor que para compreender o passado, seria preciso "deslocar-se ao espírito da época" (idem), na medida em que somente imerso nesse espírito seria possível reconstruir e reviver algo que se encontraria exclusivamente no próprio passado. A prova de que a distância temporal não é um problema, mas antes uma vantagem, se revela, por exemplo, no juízo sobre a arte:

Todo o mundo conhece essa peculiar impotência do juízo, aí onde não há a distância do tempo a nos proporcionar padrões seguros. Assim, o juízo sobre a arte contemporânea reveste, para a consciência científica, uma desesperadora insegurança. Quando nos aproximamos destas criações o fazemos, evidentemente, a partir de preconceitos incontroláveis, pressuposições que possuem sobre nós demasiado poder para que possamos conhecê-las (...). (GADAMER, 1997, p.445)

Do mesmo modo que ocorre na arte, experimentamos também certa insegurança diante dos acontecimentos nas esferas da vida social e política. Quanto mais próximos e recentes, maior nossa dificuldade em emitir juízo sobre algo que nos acomete. Temos a sensação de que precisamos de algum afastamento para avaliar de modo mais seguro, tanto as mudanças que ocorrem de forma lenta e gradual, quanto aquilo que surge de repente como novo. Gadamer diz que "essa experiência levou a investigação histórica à conclusão de que um conhecimento objetivo só pode ser alcançado a partir de uma certa distância histórica". (1997, p.446). 
A distância histórica permite colocar, então, como objeto de investigação, tudo aquilo que foi produzido dentro de um determinado espaço de tempo. O que permite que nos debrucemos, em última análise, sobre esse mesmo tempo. Esse distanciamento, contudo, não pode ser tomado como um colocar-se de fora das relações que nos permeiam, de modo a olhar para a coisa como se ela não produzisse sobre nós mais nenhum efeito. A ideia não é buscar uma objetividade asséptica com relação ao que se deu no passado. O sentido daquilo que foi escrito em um texto, por exemplo, está sujeito a sofrer mudanças, a se transformar ou, ainda, a se mostrar de outras maneiras. Mais uma vez, o texto não será recebido pelo intérprete apenas sob o "aspecto puramente ocasional que representam o autor e seu público originário.” (1997, p. 444). Seu sentido passará a ser determinado pela "situação histórica do intérprete, e, por consequência, por todo processo histórico" (idem) pelo qual o texto e seu intérprete foram atravessados. Desse modo:

O sentido de um texto supera seu autor não ocasionalmente, mas sempre. Por isso a compreensão não é nunca um comportamento somente reprodutivo, mas é, por sua vez, sempre produtivo. Talvez não seja correto falar de "compreender melhor" em relação a esse momento produtivo inerente à compreensão. Pois já vimos que essa fórmula é a conversão de um postulado básico da crítica objetiva da época da Aufklärung sob o fundamento da estética do gênio. (...) Bastaria dizer que, quando se logra compreender, compreende-se de um modo diferente. (idem)

Mesmo quem refaz a leitura de um texto poderá perceber o quanto este pode se mostrar de diferentes maneiras. Isso porque aquele que lê um texto, faz isso a partir de expectativas de sentido produzidas pelos preconceitos que orientam essa primeira leitura. A releitura desse mesmo texto será guiada não mais por essas primeiras expectativas, mas incluirá outras novas que foram produzidas pela primeira leitura. Assim, nunca se lê o mesmo texto duas vezes, uma vez que o sentido do que foi escrito somente se revelará nesta tensão entre o texto e os preconceitos que orientam a leitura de quem o interpreta.

Da mesma forma, nenhuma situação hermenêutica se repete de maneira idêntica. Como na famosa frase de Heráclito que revela a impossibilidade tanto do rio quanto daquele que nele entra de serem os mesmos a cada vez que se entra nele. Embora não possamos ignorar que ainda exista algo que se preserve, uma vez que o rio continua a ser rio. 
A mencionada crítica de Gadamer à doutrina estética do gênio chama a atenção para o fato de que a busca pelo sentido não é uma busca que parte da subjetividade do intérprete até a subjetividade do autor. Como já vimos na crítica de Gadamer a Schleiermacher, essa busca culminaria em uma necessidade de transferir-se por completo para o interior da constituição psíquica do autor original de modo a tornar possível adivinhar e completar o sentido daquilo que ele quis dizer em sua obra. O intérprete seria, então, um coautor da obra, como se o sentido estivesse em posse da subjetividade do autor e do intérprete. O que Gadamer aponta com a distância temporal é que a compreensão não está sob a posse do autor ou do intérprete como indivíduos, mas que o horizonte da compreensão é mais fundamental que a pretensa genialidade dos sujeitos. Um sujeito que se encontra cem anos depois de um acontecimento poderá ter mais elementos interpretativos para compreender o que aconteceu do que quem lá esteve. A compreensão sobre esse acontecimento não se funda no gênio de um historiador, por exemplo, mas no modo como ele se relaciona com os elementos interpretativos que ele encontra ao longo de sua investigação.

O que nos permite compreender um texto escrito em outras épocas tem muito mais a ver com a relação que criamos com os preconceitos que a nossa tradição nos fornece do que algo que se inaugura em nossa subjetividade. Ainda assim, a nossa compreensão é sempre produtiva com respeito àquilo que se deu no passado.

Assim como Gadamer, Walter Benjamin em seu famoso ensaio Sobre o Conceito da História, também criticou o historicismo. Para Benjamin, o historicismo vê a história como uma sucessão de fatos que estabelecem uma relação de causa e efeito entre si:

O historicismo se contenta em estabelecer um nexo causal entre vários momentos da história. Mas nenhum fato, meramente por ser causa, é só por isso um fato histórico. Ele se transforma em fato histórico postumamente, graças a acontecimentos que podem estar dele separados por milênios. (BENJAMIN, 2008, p.232)

Desse modo, na interpretação de Benjamin, o historicismo recorta e aproxima de modo arbitrário, tudo aquilo que serve para fundamentar e fixar uma determinada narrativa. Soma-se a isso o fato de que, esse modo de compreender a 
história, guarda uma tendenciosa "empatia com os vencedores", que são sempre alçados à posição de "herdeiros de todos os que venceram antes" (idem).

Para Benjamin, "o historiador consciente disso renuncia a desfiar entre os dedos os acontecimentos, como as contas de um rosário.” (idem). Ele vê no presente um "agora" no qual se infiltram "estilhaços do messiânico" de épocas anteriores.

Em sua teleologia messiânica ${ }^{18}$, Benjamin vê a possibilidade de haver na história uma unidade ou um fim, no qual "somente a humanidade redimida poderá apropriar-se totalmente de seu passado" (idem). Como na passagem abaixo, Benjamin acredita na possibilidade de, na história, ainda se revelar aquilo que foi escondido nas narrativas dos vitoriosos:

\begin{abstract}
O passado traz consigo um índice misterioso, que o impele à redenção. Pois não somos tocados por um sopro do ar que foi respirado antes? Não existe, nas vozes que escutamos ecos de vozes que emudeceram? Não têm as mulheres que cortejamos irmãs que elas não chegaram a conhecer? Se assim é, existe um encontro secreto, marcado entre as gerações precedentes e a nossa. Alguém na terra está à nossa espera. Nesse caso, como cada geração, foi-nos concedida uma frágil força messiânica para a qual o passado dirige um apelo. Esse apelo não pode ser rejeitado impunemente. O materialista histórico sabe disso. (BENJAMIN, 2008, p.223)
\end{abstract}

Podemos ver aqui que há uma aproximação com o que a hermenêutica gadameriana compreende por integração. Aquilo que herdamos da nossa tradição se integra ao nosso presente e revela-se sempre de modo novo. A maneira como concebemos o passado pode, então, ser sempre alterada, o que confere a ele um caráter dinâmico. Por essa razão, Benjamin vê o tempo presente como um tempo vivo que entrecruza passado e futuro num mesmo agora, uma vez que nele existe um encontro marcado entre nossos antepassados e as gerações futuras. $\mathrm{O}$ autor guarda em sua visão sobre a história a possibilidade de haver um momento em que tudo aquilo que foi silenciado pela narrativa dos vitoriosos, possa ressurgir, havendo assim a redenção dos vencidos.

Benjamin é um autor que resiste a uma sistematização de seu pensamento. Uma vez que toda a sua reflexão se encontra na forma de breves ensaios e fragmentos, qualquer tentativa de fixá-la é problemática. Como caracteriza Löwy:

\footnotetext{
${ }^{18} C f$. LÖWY, Michael. A filosofia da história de Walter Benjamin. Palestra feita pelo autor em 28 de janeiro de 2002 na sede do Instituto de Estudos Avançados da USP. Disponível em: http://www.scielo.br/pdf/ea/v16n45/v16n45a13.pdf Acesso em 21 de janeiro de 2020.
} 
A filosofia da história de Walter Benjamin bebe em três fontes diferentes: o romantismo alemão, o messianismo judeu e o marxismo. Não é uma combinatória ou "síntese" dessas três perspectivas (aparentemente) incompatíveis, mas a invenção, a partir delas, de uma nova concepção, profundamente original. (idem)

Mesmo diante da difícil tarefa de nos apropriarmos dos escritos de Benjamin e de os compormos em uma unidade coerente, podemos ainda assim, em alguma medida, tentarmos nos aproximar das metáforas por ele produzidas em seus textos, na medida em que elas parecem revelar algo bastante similar ao que a hermenêutica gadameriana também nos revela. Uma dessas metáforas seria a de que "o passado só se deixa fixar, como uma imagem que relampeja irreversivelmente, no momento em que é reconhecido" (BENJAMIN, 2008, p.224). Essa passagem revela a atualidade e a atualização de toda a visão que podemos constituir sobre o passado, uma vez que ela sempre se dá no momento presente, algo que também aparece em outro ensaio, que se intitula Cavando e Recordando. Nesse ensaio Benjamin afirma que "se ilude, privando-se do melhor, quem só faz o inventário dos achados e não sabe assinalar no terreno de hoje o lugar no qual é conservado o velho" (2000, p.239). Aqui, se apresenta a ideia do tempo presente como o lugar no qual é possível encontrar-se com o passado.

Benjamin também torna evidente a fecundidade hermenêutica da distância temporal, quando afirma, nesse mesmo ensaio, que:

Antes de tudo, não se deve temer voltar sempre ao mesmo fato, espalhá-lo como se espalha a terra, revolvê-lo como se revolve o solo. Pois "fatos" nada são além de camadas que apenas à exploração mais cuidadosa entregam aquilo que recompensa a escavação. Ou seja, as imagens que, desprendidas de todas as conexões mais primitivas, ficam como preciosidades nos sóbrios aposentos de nosso entendimento tardio, igual a torsos na galeria do colecionador. (idem)

Gadamer, por sua vez, também reconheceu a atualidade de toda compreensão acerca do passado e sua necessária vinculação com o presente, haja vista que estamos atravessados por uma tradição na qual a todo o momento se pode reafirmar ou despotencializar preconceitos. Desse modo, Gadamer não desconsideraria a possibilidade de haver transformações nos preconceitos que orientam nossa compreensão. Essa possibilidade de nos colocarmos diante de nossos próprios preconceitos, no entanto, exigiria que eles já não se encontrassem atuantes com "todo seu vigor". Valendo-nos de outros preconceitos, portanto, poderíamos nos colocar diante daqueles que antes não eram percebidos: 
É claro que destacar um preconceito implica em suspender sua validez. Pois, na medida em que um preconceito nos determina, não o conhecemos nem o pensamos como um juízo. Como poderia então ser destacado? Conseguir por um preconceito diante dos olhos é impossível enquanto este estiver constante e desapercebidamente em obra, porém somente quando, por assim dizer, ele é atraído por estímulo. Esse estímulo procede precisamente do encontro com a tradição. (GADAMER, 1997, p. 447)

$\mathrm{O}$ estímulo, que permitiria esse encontro, seria o fenômeno da pergunta. $\mathrm{Na}$ medida em que, "a essência da pergunta é a de abrir e manter abertas possibilidades" (idem) ela permite a suspensão de um juízo, torna-o objeto de novas interpretações. Porém, o fato de um preconceito ter se tornado visível e questionável, não implica necessariamente que ele deixe de servir à compreensão:

Quando um preconceito se torna questionável face ao que nos diz outra pessoa ou um texto - isso não quer dizer consequentemente que ele seja simplesmente deixado de lado e que o outro ou o diferente venha a substituí-lo imediatamente em sua validez. (GADAMER, 1997, p. 447/448)

Diferentemente de Benjamin, na visão de Gadamer, a história não se orienta para um fim que unificaria todo o seu sentido. Assim como acontece na filosofia heideggeriana, vemos na leitura de Gadamer que é na experiência de mundo que se funda e se origina toda e qualquer compreensão acerca do próprio mundo. Isto se revela, mais uma vez, no modo como a hermenêutica descreveu a circularidade da compreensão. Gadamer reconhece a possibilidade de haver compreensões concorrentes, disputas infindáveis que envolvem e tensionam diferentes preconceitos dentro de uma mesma tradição.

A existência de interesses e visões antagônicas é, inclusive, o que resguarda o sentido da política, uma vez que não é possível, e nem desejável, equalizar as diferenças de modo que todos possam viver de maneira semelhante sob os mesmos valores e crenças. E, também, por outro lado, na medida em que não se pode reivindicar uma razão que transcenda os contextos históricos de sua formação, o que os governos deveriam buscar entre si seria a "a manutenção de um equilíbrio". (GADAMER, 2004, p.194).

Outro aspecto a ser destacado na leitura de Gadamer sobre a história é o efeito que o próprio modo de compreender a história produz. Isso porque, "um pensamento verdadeiramente histórico tem de pensar ao mesmo tempo a sua própria historicidade" (1997, p.448). Isso significa dizer que não somente aquilo 
que foi suspenso com a pergunta tem um caráter histórico, mas também a própria pergunta. Uma pergunta sempre é uma pergunta sobre algo, o que significa dizer que ela, de alguma maneira, já sempre carrega consigo aquilo que ela busca. Para Gadamer, aquele que investiga a história precisa ter isso em vista, pois:

Só então deixará de perseguir o fantasma de um objeto histórico, que é objeto de uma investigação progressiva, aprenderá a conhecer no objeto o diferente do próprio e conhecerá assim tanto um quanto outro. O verdadeiro objeto histórico não é um objeto, mas é a unidade de um e de outro, uma relação na qual permanece tanto a realidade da história como a realidade do compreender histórico. Ao que é exigido com isso, eu chamo de "história efeitual". (GADAMER, 1997, p.448)

Na leitura de Palmer, o que Gadamer sinaliza com isso é que, "não há uma visão ou uma compreensão puras da história, sem referência ao presente" (PALMER, 2015, p.180). Pelo contrário, a história é vista e compreendida apenas e sempre em vista de uma consciência que se situa no presente. Essa consciência carrega interpretações sobre o passado e seus efeitos não "como um amontoado de fatos que se possam tornar objeto de consciência, mas antes como um fluxo em que nos movemos e participamos em todo ato de compreensão" (idem).

Quando procuramos compreender um fenômeno a partir da distância histórica que determina a nossa situação hermenêutica como um todo, encontramo-nos sempre sob os efeitos dessa história efeitual. Ela determina de antemão o que se mostra para nós de questionável e como objeto de investigação, e nós esquecemos logo a metade do que realmente é, mais ainda esquecemos toda a verdade deste fenômeno, a cada vez que tomamos o fenômeno imediato como toda a verdade. (GADAMER, 1997, p.449)

Vale lembrar que o descrito acima, é uma tarefa essencialmente científica, uma vez que compreensão é autoesquecimento, como nos lembra Gadamer (2004, p.104). Compreendemos o mundo quando nos guiamos por ele sem que ele precise a todo instante ser objeto de nosso questionamento. Guiamo-nos por nossos preconceitos e não os colocamos a todo instante em suspenso. Não nos perguntamos a todo o momento sobre eles. Isso, porque:

Antes de todo pensar crítico, filosófico-interventivo, o mundo já sempre se nos apresenta numa interpretação feita pela linguagem. $\mathrm{O}$ mundo se articula para nós no aprendizado de uma língua, na assimilação de nossa língua materna. Isso é muito mais uma primeira abertura do que um engano. Inclui, por certo, que o processo da formação conceptual, iniciado no âmbito dessa interpretação feita pela linguagem, nunca é um primeiro começo. Não equivale a forjar uma nova ferramenta a partir de um material apropriado, uma vez que se trata de um continuar a pensar na língua que falamos e na interpretação do mundo nele contida. Nunca se trata de um começar do zero. (GADAMER, 2002, p.97) 
Assim, como falantes de uma língua, herdamo-la, já nos encontramos dentro da língua que falamos e compreendemos. Isso significa dizer que participamos de um mundo que se encontra para nós linguisticamente estruturado. A tematização desse mundo implica em produzir um estranhamento com relação a ele. Essa tematização pressupõe, mais uma vez, uma abertura e a possibilidade de colocar em jogo nossos preconceitos. Reconhecer nossa própria situação hermenêutica é uma tarefa que Gadamer admite não ser fácil. Uma vez que "estamos nela, já nos encontramos sempre numa situação cuja iluminação é a nossa tarefa, e esta nunca pode se cumprir por completo" (1999, p. 451). Isso não seria, no entanto, um defeito da nossa consciência ou da nossa reflexão, mas antes a "essência mesma do ser histórico que somos. Ser histórico quer dizer não se esgotar nunca no saberse.” (idem). Portanto, um estágio de autoiluminação e de plena consciência histórico-efeitual seria inalcançável, uma vez que a nossa própria situação histórica, que nos mantém vinculados a ela mesma e a nós mesmos, é o mesmo ponto de partida que permite tal reflexão. Para ilustrar com uma metáfora, seria como tentar fazer tal qual o já bastante citado Barão de Münchhausen que, em uma de suas aventuras, consegue tirar a si mesmo do pântano puxando os próprios cabelos, ou os cadarços das botas com as quais está calçado.

\section{5. \\ Horizontes históricos e fusão de horizontes}

Horizonte é o âmbito de visão que abarca e encerra tudo o que é visível a partir de um determinado ponto. Aplicando-se à consciência pensante, falamos então de estreiteza do horizonte, da possibilidade de ampliar o horizonte, da abertura de novos horizontes etc. (...) Aquele que não tem horizonte é um homem que não vê suficientemente longe e que, por conseguinte, supervaloriza o que está mais próximo. Pelo contrário, ter horizontes significa não estar limitado ao que há de mais próximo, mas poder ver para além disso. Aquele que tem horizontes sabe valorizar corretamente o significado de todas as coisas que caem dentro deles, segundo os padrões de próximo e distante, de grande e pequeno. (GADAMER, 1999, 452)

Antes de tudo, é importante frisar que Gadamer aproxima ao máximo o conceito de horizonte do sentido que comumente utilizamos. Em nosso uso habitual da linguagem, costumamos empregar precisamente os termos "abrir nossos horizontes", ou que alguém "tem horizonte", com o sentido de amplitude e 
variação de um determinado campo de visão, de conseguir enxergar mais adiante, de estender nossos conhecimentos de mundo e com isso perceber que existem muito mais coisas a serem descobertas do que anteriormente pressupúnhamos. Em um olhar mais atento a esse sentido indicado pelo conceito de horizonte, podemos observar que a educação ganha então uma fundamental importância para a expansão e pluralização de nossas capacidades interpretativas, e não falamos somente da educação formal e institucionalizada, embora tenhamos evidentemente uma maior atenção sobre ela, mas também a que ocorre na família e nos ambientes informais ao longo da vida de um indivíduo. Dentro dos debates mais especializados, vamos mais além e atribuímos ao processo educacional não só a incumbência de munir os alunos com conhecimentos a respeito das coisas, com também de estimular o desenvolvimento da sua capacidade de refletir sobre esses conhecimentos de forma independente e de serem participantes ativos na produção de novos conhecimentos. Ganhar horizontes deve ser então compreendido não apenas como um tomar conhecimento das coisas, mas como uma participação efetiva do acontecimento do aprendizado.

Vale ressaltar, contudo, que o ser humano descrito por Gadamer, que ganha horizontes à medida que ousa enxergar mais longe, tem um significado muito distinto daquele pensado a partir dos moldes da filosofia moderna. De acordo com Gadamer, só é capaz de afastar-se criticamente de uma tradição aquele que nela se encontra, apoiando-se não em uma subjetividade racional transcendente, mas sim em outras narrativas que ele pode experimentar, por exemplo, na arte, na literatura ou mesmo na relação direta com outros sujeitos por meio do diálogo. Ser capaz de produzir uma elaboração a respeito de nossa própria "situação hermenêutica significa então a obtenção do horizonte de questionamento correto para as questões que se colocam frente a tradição.” (GADAMER, 1999, p.452). Isto só é possível de se fazer a partir da própria situação histórica e em diálogo com diferentes narrativas, como já discutimos.

Ressaltamos também que Gadamer caracterizou todo o processo de educação como algo que o indivíduo realiza em virtude de si mesmo na sua relação com o outro, um processo em que ele se apropria daquilo que se the apresenta, produzindo um estranhamento e tornando a se familiarizar com ele. $\mathrm{Na}$ visão do autor, esse "educar-se" se dá desde sempre, e fica ainda mais evidente, nas primeiras tentativas de aprendizado da língua oral, quando é possível perceber 
a particular "satisfação de uma criança que está crescendo e começa a repetir o que não entende". (GADAMER, 2000, p.16) Esse processo ocorre, para Gadamer, dessa maneira porque:

Aprender a falar não significa ser introduzido na arte de designar o mundo que nos é familiar e conhecido pelo uso de um instrumentário já dado, mas conquistar a familiaridade e o conhecimento do próprio mundo, assim como ele se nos apresenta. (GADAMER, 2002, p.176)

Assim, ganhar horizontes compreensivos é algo que realizamos na linguagem. Uma vez que nossa compreensão se estrutura linguisticamente, a aquisição de horizontes requisita a nossa capacidade de interagirmos com os outros e de dialogarmos:

Em todos os nossos pensamentos e conhecimentos sempre já fomos precedidos pela interpretação do mundo feita na linguagem, e essa progressiva integração no mundo chama-se crescer. Nesse sentido, a linguagem representa o verdadeiro vestígio de nossa finitude. (GADAMER, 2002, p.178)

Em nossa linguagem somos capazes de articular o mundo compreendido e, também, de nos encontrarmos com aquilo que não nos é familiar. Gadamer, inclusive reconhece nesse limiar o lugar em que se efetiva a tarefa de toda hermenêutica, tal como acentua também Schmidt:

"o lócus da hermenêutica é este "entre" [VM: 295], entre aquilo que é familiar ou compartilhado e aquilo que é estranho no texto. $\mathrm{O}$ daquilo que é estranho em um texto permite que o intérprete questione aquilo que é familiar e normalmente aceito sem perguntas. (SCHMIDT, 2014, p.151)

Aqui, é importante trazer para esse momento do debate o que Gadamer denominou como sendo a "concepção prévia da perfeição" (1997, p.440). Para o autor, é esta concepção prévia o que nos condiciona a abordar um determinado texto, ou mesmo uma determinada situação e, presumirmos que nela exista uma unidade de sentido. Quando não alcançamos esse sentido, percebemos que nos faltam elementos e que precisamos tomar conhecimento destes para que o sentido se complete. Eventualmente imaginamos que aquilo que se apresenta possa ter uma falha em sua concepção que impeça que ele seja compreendido, contudo, quando essa falha existe de fato, por vezes, somos orientados a completar essa espécie de lacuna, para que o sentido também se complete. Com isso, acrescentamos ao texto algo que antes não estava lá. Nas palavras de Gadamer: 
(...) o sentido desse círculo, subjacente a toda compreensão, possui uma nova consequência hermenêutica (...) somente é compreensível o que apresenta uma unidade perfeita de sentido. Fazemos tal pressuposição da perfeição quando lemos um texto, e somente quando esta se manifesta como insuficiente, isto é, quando o texto não é compreensível, duvidamos da transmissão e procuramos adivinhar como pode ser remetida. (GADAMER, 1997, p.440)

Mesmo diante de um sentido completo, é possível ainda nos darmos conta de que o texto carece de verossimilhança, ou seja, que aquilo que ele apresenta não tem correspondência com o que compreendemos por verdadeiro. Não podemos esquecer que "também nós entendemos os textos transmitidos sobre a base de expectativas de sentido que extraímos de nossa própria relação precedente com o assunto" (GADAMER, 1997, p.441). Sendo assim, esse encontro tem o potencial de iluminar nossos próprios preconceitos e colocá-los em questão. Podemos com isso, aprender algo com o texto, perceber que os nossos preconceitos são insuficientes e que o texto consegue dizer algo mais razoável sobre a coisa em questão. Por outro lado, podemos também, num movimento contrário, reconhecer que aquilo que ele diz perdeu sua validez, que nossa situação histórica não parece mais corresponder aquilo que os seus preconceitos intencionam. Por conta disso, Gadamer defendeu que:

\begin{abstract}
Não se pressupõe somente uma unidade imanente de sentido que possa guiar o leitor, mas que a compreensão deste esteja guiada constantemente por expectativas de sentido transcendente, que surgem de sua relação com a verdade daquilo a que o texto intenciona. (...) O preconceito da perfeição contém, pois, não somente a formalidade de que um texto deve expressar perfeitamente sua opinião, mas também de que o que diz é uma verdade perfeita. (GADAMER, 1997, p.440)
\end{abstract}

Um texto que nos requisita a reconstrução de sua situação histórica para ser compreendido é um texto que renunciou "definitivamente à pretensão de encontrar na tradição uma verdade compreensível que possa ser válida para nós mesmos". (GADAMER, 1997, p.454). Desse modo, ele está "privado formalmente de sua pretensão de dizer a verdade" (idem). Como exemplifica Gadamer, um texto sagrado não deseja ser compreendido como um objeto histórico, ele presume poder dizer a verdade e poder se integrar à vida em qualquer época.

A esse movimento de encontro entre horizontes históricos, Gadamer deu o nome de fusão de horizontes. O horizonte do outro, que no caso descrito, é o horizonte do texto, apresenta-se para nós permeado de preconceitos oriundos de 
sua situação histórica. Assumimos nesse encontro a possibilidade de ver nesse outro mais além do que temos visto em nossa própria posição e, com isso, colocamo-nos em direção a uma expansão compreensiva a respeito de algo. Os horizontes a que se vinculam texto e intérprete, contudo, não se encontram cindidos um do outro, ou fechados por completo. Gadamer nos diz que:

A mobilidade histórica da existência humana apoia-se precisamente em que não há uma vinculação absoluta a uma determinada posição, e nesse sentido tampouco existe um horizonte fechado. O horizonte é antes algo no qual trilhamos nosso caminho e que conosco faz o caminho. Os horizontes se deslocam ao passo em que se move. Também o horizonte do passado, no qual vive toda a vida humana e que está aí sob a forma de tradição põe em movimento o horizonte abrangente. $\mathrm{Na}$ consciência histórica este movimento tão-somente se torna consciente de si mesmo. (...) Na realidade, trata-se de um único horizonte, que rodeia tudo quanto contém em si mesma a consciência histórica. (GADAMER, 1997, p.455)

Essa consciência histórica que nos permite compreender e investigar o passado em seu próprio ser, "não a partir de nossos padrões e preconceitos contemporâneos, mas a partir de seu próprio horizonte histórico" (GADAMER, 1997, p.452), é o que nos permite desnaturalizar ou até mesmo dessubjetivar alguns de nossos preconceitos, na medida em que "não é verdade que se ganhe esse horizonte deslocando-nos a uma situação histórica, pelo contrário, temos de ter sempre um horizonte para podermos nos deslocar a uma situação qualquer." (GADAMER, 1997, p. 455).

Como os seres histórico que somos, não inauguramos a partir de nossa subjetividade um ponto de vista totalmente apartado da nossa situação, tampouco podemos ignorar que trazemos conosco os modos de compreensão de nossa tradição. Nós carregamos tanto os preconceitos que se mostram apropriados para compreender as coisas, quanto aqueles que se mostram problemáticos e ilegítimos. O desejo que temos de não nos orientamos pelos últimos não significa de modo algum que eles possam ser retirados definitivamente de uma vez por todas de nossa compreensão. Muito pelo contrário, numa situação em que nos colocamos na posição de combate a esses preconceitos, ficamos ainda mais atentos a eles uma vez que reconhecemos sua vinculação com a tradição e reconhecemos de maneira tácita como eles se entrelaçam necessariamente com a nossa própria compreensão. Em outras palavras, quando realizamos um questionamento a respeito dos preconceitos que nos parecem ilegítimos, nós 
fazemos isso à luz de nossa própria compreensão por meio da pergunta. Em outras palavras, como já vimos acima, a essência da pergunta consiste em que ela carrega uma compreensão prévia acerca daquilo que é perguntado, pois toda pergunta é uma pergunta sobre algo. Quando questionamos um preconceito notoriamente ilegítimo, ele acaba por reaparecer como uma orientação hermenêutica para a pergunta. Nesse movimento questionador, tentamos suspendê-lo à medida que o questionamos à luz da articulação de novos preconceitos.

Essa confrontação entre preconceitos, contudo, já acontece no próprio movimento histórico que constitui os horizontes e a chamada tradição. Nas palavras de Gadamer: "A fusão se dá constantemente na vigência da tradição, pois nela o velho e o novo crescem sempre juntos para uma validez vital, sem que um e outro cheguem a se destacar explicitamente por si mesmos.” (1997, p.457). Portanto, "o velho e o novo" se interpenetram de diversas maneiras e, por isso, nunca estão separados por completo. Gadamer, então, questiona: "Mas se não existem esses horizontes que se destacam uns dos outros, porque falamos então de fusão de horizontes e não simplesmente da formação desse horizonte único?" (1997, p.458). Evidentemente, isso implicaria na existência de uma unidade de sentido presente em toda a história e de um encadeamento linear, sem sobreposições e contradições, algo que, como observamos com Benjamin, só é possível quando existe uma leitura eletiva da história, que privilegia apenas uma narrativa. Para Gadamer, "o encontro com a tradição realizado com consciência histórica experimenta por si mesmo a relação de tensão entre texto e presente" (idem), este é o ponto em que a fusão é capaz de revelar algo e ao mesmo tempo revelar a si mesma.

Portanto, diferentemente do que se possa imaginar, a fusão não ocorre entre duas posições fixas, que simplesmente alcançariam, por meio de uma síntese voluntária, um horizonte consensual. A fusão também é algo já dado no próprio horizonte em que nos movemos. Como mostra o poema de Brecht a seguir:

As novas épocas não começam de repente.

Meu avô já vivia num tempo novo, meu neto com certeza ainda vai viver no antigo. A carne nova é comida com os velhos garfos. (apud KONDER, 1996, p.70) 
Gadamer, assim como Brecht, observou que "o horizonte do presente não se forma, pois, à margem do passado. Nem mesmo existe um horizonte do presente por si mesmo, assim como não existem horizontes históricos a serem ganhos." (GADAMER, 1997, p. 457). Ambos se encontram presentes em nossa compreensão, orientando-nos com relação a e fazendo se revelarem, em todas as nossas ações e juízos, quais são os princípios que adotamos. Aqui, então, podemos pensar que uma possível tarefa da educação seria a mesma que Gadamer atribui à sua filosofia: "A tarefa hermenêutica consiste em não dissimular essa tensão em uma assimilação ingênua, mas em desenvolvê-la conscientemente" (GADAMER, 1999, p. 377). A ideia está em levar aquele que aprende a enxergar que, em seu tempo e em seu compreender, coexistem diferentes modos de interpretação do mundo que se entrelaçam e se fundem e que estes podem ser concorrentes, opostos ou complementares entre si. A adesão a esse horizonte não é uma prerrogativa voluntária dos sujeitos, mas a própria condição de sua compreensão. Desse modo, é sempre a partir de uma compreensão prévia de si mesmo e do mundo que ocorre uma nova compreensão. A maneira particular que carregamos conosco de conceber as coisas pode ser elucidada em certa medida quando elucidamos a própria historicidade do nosso ser. Reconhecemos assim, os princípios pelos quais temos nos orientado e, no lugar de buscarmos uma negação dos preconceitos, podemos buscar tornar evidente sua historicidade e então questionar sua legitimidade. Assumimos assim nossa responsabilidade por eles como sujeitos.

\section{6.}

\section{Diálogo como fusão de horizontes: Gadamer e o diálogo verdadeiro}

Não é por acaso que Gadamer é conhecido como o filósofo do diálogo, como bem observa Grondin, "a hermenêutica de Gadamer nasceu realmente da práxis do diálogo." (GRONDIN, 2012, p.20). Sobretudo, são significativos os diálogos que ele estabeleceu com os mais variados pensadores de que se aproximou, tanto pela leitura e comentário de suas obras quanto pela convivência direta nas Universidades pelas quais passou. Desse modo:

Gadamer exerceu a arte do diálogo, da capacidade de ouvir, de reconhecer o outro também como professor e autor. Sua obra principal - sob essas condições só poderia ser uma hermenêutica geral - nasceu pela pressão de seus alunos e 
parceiros de diálogo que exigiam dele mostras do que asseverava. Alguma coisa nele sempre resistiu ao caráter monológico da escrita. (...) Talvez Verdade e Método tenha se tornado tão abrangente, porque Gadamer precisou dar testemunho da multiplicidade de seus parceiros de diálogo e fontes de experiência. (GRONDIN, 2012, p.10)

Apesar de Gadamer se apoiar fundamentalmente na ontologia heideggeriana, ele se desvia dela em determinado ponto e vai ao encontro da filosofia dialógica de Platão, assumindo que a linguagem possui essencialmente uma estrutura de diálogo. Assim, se, por um lado, ele se vale da estrutura da compreensão, trazida por Heidegger, de uma forma também bastante peculiar, por outro, ele torna explícita a linguagem dialógica inerente à relação dos indivíduos e seus horizontes históricos compreensivos. Ao mesmo tempo, Gadamer observa o modo como na civilização atual o discurso tecno-científico conduz o homem a uma existência monológica que se reflete na "crescente incapacidade para o diálogo". Sobre isso ele levanta algumas hipóteses:

\begin{abstract}
A arte do diálogo está desaparecendo? Na vida social de nossa época não estamos assistindo a uma monologização crescente do comportamento humano? Será um fenômeno típico de nossa civilização que acompanha o modo de pensar técnicocientífico? Ou será que as experiências específicas de auto-alienação e de isolamento presentes no mundo moderno é que fazem os mais jovens se calar? Ou será ainda que o que se tem chamado de incapacidade para o diálogo não é propriamente a decisão de recusar a vontade de entendimento e uma mordaz rebelião contra o pseudo-entendimento dominante na vida pública? (GADAMER, 2004, p.242)
\end{abstract}

O diálogo, para Gadamer, revela um traço essencial da linguagem que é "a ausência de um eu" (2002, p.179). Isso porque, falar é sempre falar para alguém, o que coloca a linguagem na "esfera do nós" (idem). Assim, "a palavra quer ser palavra que vai ao encontro de alguém. Mas isso não significa apenas que a coisa em questão, referida pela palavra, se apresente diante de mim, mas que se apresente também a aquele com quem eu falo.” (idem). Quando um diálogo se dá na conversa entre duas pessoas, a palavra deve fazer surgir a coisa em questão para que ambos a vejam. Desse modo, ambos se orientam pela própria coisa e aquilo que é possível dizer sobre ela, o que faz com que ela se mostre ou não. Algumas vezes temos a sensação de que alguém conseguiu mostrar muito bem algo por meio da palavra. Outras vezes, pelo contrário, aquilo que o outro nos diz não se parece com a coisa como a experimentemos. Assim, Gadamer percebe que: 
Também aqui vemos confirmado que compreender significa, primariamente, sentirse entendido na coisa, e somente secundariamente destacar e compreender a opinião do outro como tal. Assim, a primeira de todas as condições hermenêuticas é a pré-compreensão que surge do ter de se haver com a coisa em questão. (GADAMER, 1997. p. 441)

Lembramos que coisa (Sache) guarda o sentido daquilo que é experimentando fenomenologicamente. A coisa "caracteriza-se sobretudo pelo conceito oposto de pessoa" (GADAMER, 2002, p.82), o que significa dizer que a pessoa tem precedência com relação a coisa. A coisa é algo de que dispomos e que utilizamos. Entretanto, a coisa, como revela Gadamer, "tem em si próprio um ser, em virtude do qual pode opor resistência, a partir de sua própria natureza, ao uso impróprio" (idem). Ou seja, mesmo sendo algo de que podemos lançar mão de forma utilitária, a coisa resiste e se impõe em certa medida a esse uso. Por mais que se possa argumentar que o sentido das coisas não está nas coisas em si, mas em seu horizonte de aparição, a coisa impõe em si um limite sobre o que se pode dizer ou fazer dela. Gadamer também afirma que é possível escutar melhor o que ele denomina como "a linguagem das coisas", algo que ele reconhece ressoar de maneira polêmica, uma vez que "expressa que, em geral, não estamos preparados para ouvir as coisas no seu ser próprio" (2002, p.84). Isso acontece porque não se estabelece mais uma relação compreensiva com as coisas, mas se as submetem de imediato "ao cálculo do homem e ao seu domínio da natureza pela racionalidade da ciência" (idem). Desse modo Gadamer, afirma que:

Num mundo que se torna cada vez mais técnico, falar de dignidade das coisas torna-se algo cada vez mais incompreensível. Elas estão desaparecendo, e somente o poeta ainda lhes resguarda uma última fidelidade. Mas o fato de ainda se poder falar de uma linguagem das coisas nos lembra que, na verdade, as coisa não são um material que se usa e consome, não são um instrumento que se utiliza e coloca de lado, mas algo que tem consciência em si e que "é impelido para o nada" (Heidegger). O arbítrio e a vontade manipuladora do homem é que desconsidera seu ser próprio interior. Esse ser é uma linguagem que se deve ouvir. (GADAMER, 2002, p.84)

Nesse momento Gadamer aponta mais uma vez para uma consciência ou uma sensibilização dos sentidos que a experiência estética nos requisita. A capacidade de ouvir a linguagem da coisa se aproxima daquilo que ele considerou acerca da experiência de verdade na obra de arte, algo que é inapreensível a partir de uma perspectiva meramente cognitiva. 
Portanto, é quando há algo efetivamente em questão para nós que pode existir um verdadeiro diálogo. Isso é muito diferente da postura que adotamos quando estabelecemos uma relação com o outro com o único propósito de conhecer algo a seu respeito. Nesse caso, pretendemos nos colocar no lugar do outro sem colocar em questão a nossa própria situação, na tentativa de experimentar, ou dar a impressão de experimentar sua posição nesse horizonte alheio. Contudo, para Gadamer, nesse caso não se pode falar de um verdadeiro diálogo, “já que os conteúdos objetivos do diálogo não são mais do que um meio para conhecer o horizonte do outro." (GADAMER, 1997, p. 453). O mesmo ocorre quando não confrontamos a verdade trazida por um texto e nos limitamos a apenas reconstruir o horizonte histórico de sua justificação. Quando não há no diálogo um conteúdo sobre o qual se busca um entendimento, estamos também desconsiderando a possibilidade de haver uma verdade acerca de algo naquilo que o outro diz. Desse modo, também não colocamos nossos preconceitos em jogo e com isso, não estabelecemos um encontro com nossas próprias opiniões prévias.

É importante salientar que diálogo, para Gadamer, refere-se à troca de experiências não em um sentido personalista, por isso, a fusão é de horizontes e não de opiniões particulares de sujeitos. Dialogar não é simplesmente confrontar falas, opiniões ou interpretações particulares, mas sim transpor-se para o horizonte de possibilidade dessas interpretações. Um verdadeiro diálogo pressupõe então a fusão de horizontes, na qual o horizonte do outro se abre para nós como uma possibilidade legítima de compreensão e a coisa, ou seja, o tema sobre o qual buscamos o entendimento aparece no confronto das concepções prévias que movimentamos.

\subsection{1.}

\section{A proximidade entre Gadamer e Buber - Sobre a experiência do tu}

Abrimos aqui um parêntese para trazer para o debate outro autor que também tem como um dos seus temas centrais o diálogo. Percebemos que a afinidade de pensamento entre Gadamer e Buber é notória quando se trata do tema do diálogo. Onde Gadamer falou de fusão de horizontes, Buber falou de união e encontro. E, onde Gadamer falou de tradição e mundo, Buber falou de concretude do mundo e contingência. Para Kepnes (1988), essa aproximação do pensamento dá-se pelo fato de ambos terem tido um mestre em comum: Dilthey. Gadamer 
chega a citar algumas vezes Buber no segundo volume de Verdade e Método. E, embora não tenha travado um debate mais explícito com o autor, é possível verificar em algumas passagens uma profunda semelhança nas ideias de ambos.

Entretanto, encontrar uma ontologia do diálogo no interior da filosofia de Buber não é uma tarefa fácil. Sobretudo porque, como observa Von Zuben (apud BUBER, 2015, p.14), na introdução que escreve em sua própria tradução da obra "Eu e Tu", Buber nunca desejou figurar como o porta-voz de um sistema filosófico. Ele acreditava ter recebido uma missão: "a de levar os homens a descobrirem a realidade vital de suas existências e a abrirem os olhos para a situação concreta que estavam vivendo" (Idem). Suas considerações sobre o diálogo aparecem essencialmente entrelaçadas a questões teológicas, sobretudo, trazidas por sua aproximação com o Chassidismo. O interesse em tematizar a religião em seus escritos, no entanto, não se limita a um esclarecimento da relação mística entre Deus e o homem. Buber inclusive questiona o dogma da vontade divina que se colocaria acima de todos os homens como o único caminho possível para a verdade e a salvação. Por vezes, ele chega a reflexões um tanto "menocchianas"19 em suas críticas aos dogmas religiosos, como, por exemplo, ao afirmar que: "não há obediência Àquele que vem sem lealdade para com a sua criatura" (2009, p.40). Para Buber, "as palavras que nos são transmitidas manifestam-se para nós no nosso humano voltar-se-um-para-o-outro" (Idem), sendo assim, "não existe palavra divina singular que possa ser inequivocamente conhecida e representada" (Idem). Isso nos leva a compreender que é na relação entre os seres humanos, por meio do diálogo, que a palavra divina pode ser conhecida. Assim, a relação possível com Deus só se dá a partir da própria relação entre os seres humanos.

É o diálogo entre os homens o que interessa Buber, pois é nele que ocorre a relação com o divino. Aqui, é importante compreender que, de acordo com o chassidismo, não existe salvação individual da alma, como veio a existir mais tarde no cristianismo. Somente a comunidade inteira pode ser salva, o que requisita aos homens se relacionarem, terem responsabilidade uns para com os outros e privilegiarem sua ação sobre o mundo:

\footnotetext{
${ }^{19}$ Menocchio é o personagem principal de Carlo Ginzburg em "O queijo e os vermes", que retrata o cotidiano e as ideias de um moleiro perseguido pela Inquisição no século XVI.
} 
Para o judaísmo, cada alma humana é um elemento que serve à criação divina, que deve se tornar reino de Deus por meio da obra dos homens; assim, nenhuma alma tem um objetivo nela mesma, em sua própria salvação. De fato, todas devem se descobrir, se manifestar, se aperfeiçoar, mas não para si mesmas, não por sua felicidade terrena, nem tampouco pela bem-aventurança celeste - mas pela obra que devem realizar no mundo de Deus. (BUBER, 2011, p.40/41)

O mundo terreno e o celeste não seriam "diferentes e separados entre si" (BUBER, 2011, p.47), ambos os mundos são um único mundo. Eles apenas se encontram afastados, mas podem encontrar uma unidade através do trabalho do homem, que é "responsável pela tarefa de realizar Deus no mundo" (BUBER, 2015, p.26). Aqui podemos perceber que há em Buber uma crítica ao dualismo metafísico mais tradicional.

Ao falar da responsabilidade do homem para consigo mesmo, para com o outro e para com o trabalho que realiza no mundo, Buber considera que essa responsabilidade se dá em resposta "a uma palavra" (2014, p.50). Contudo, ele acrescenta: "quem pratica a responsabilidade real, a responsabilidade dialógica, não precisa nomear o emissor da palavra a que está respondendo" (idem). A experiência com o divino, portanto, seria uma experiência que se dá em todo o indivíduo, independentemente se ele é religioso ou não. Essa experiência, como já foi dito, acontece necessariamente por meio do diálogo: "Um indivíduo pode rejeitar com toda força a presença de 'Deus' e, contudo ele a experimenta no austero sacramento do diálogo" (Idem).

Assim, é possível nos arriscarmos a dizer que, para Buber, Deus não é um princípio metafísico que torna possível o diálogo. Na realidade, ele se revela e é experimentado na situação dialógica, em meio ao acontecimento do diálogo. Essa "situação" é sempre inédita e imprevisível e por isso exige de nós sempre uma resposta diferente e adequada, sendo assim, a ação do ser humano não pode ser regida por uma lei divina anterior a ela.

\section{7. \\ O não-diálogo}

Se, por um lado, Buber considerou que é possível haver no diálogo um voltar-se-um-para-o-outro, por outro lado, também é possível haver um pretenso diálogo, isto é, um monólogo que quer se passar por diálogo: 
Conheço três espécies de diálogo: O autêntico - não importa se falado ou silencioso - onde cada um dos participantes tem de fato em mente o outro ou os outros na sua presença e no seu modo de ser e a eles se volta com a intenção de estabelecer entre eles e si próprio uma reciprocidade viva; o diálogo técnico, que é movido unicamente pela necessidade de um entendimento objetivo; e o monólogo disfarçado de diálogo, onde dois ou mais homens reunidos num local, falam, cada um consigo mesmo, por caminhos tortuosos estranhamente entrelaçados e creem ter escapado, contudo ao tormento de ter que contar apenas com os próprios recursos. (BUBER, 2014, p. 54)

Na terceira forma de diálogo, descrita por Buber, não há reciprocidade entre os participantes. Cada um dos que dialogam fala consigo mesmo. Não há a necessidade de comunicar algo, aprender algo, ensinar algo à alguém, ou simplesmente entrar em contato com alguém. O que orienta essa terceira forma de diálogo é o desejo de ver a si próprio "decifrando no outro a impressão deixada". O que resulta num movimento de "dobrar-se-em-si-mesmo". (BUBER, 2014, p.54).

Para Gadamer, o que nos permite o diálogo é estarmos desde sempre vinculados a um mundo que nos dá um horizonte de sentido capaz de se fundir com outros horizontes, o que nos permite, por conseguinte, compreendermos uns aos outros. Na situação do diálogo, primeiramente, há um movimento de "sentirse entendido na coisa", para em seguida se distinguir a opinião do outro como sendo do outro e não nossa. Estarmos vinculados à coisa sobre a qual nos referimos no diálogo é pertencer a uma tradição comum, que nos garante um conjunto de preconceitos fundamentais e nos permite ter, em um diálogo, uma compreensão formada com relação às coisas. Gadamer, contudo, não desconsidera o fato de que há aqui uma tensão entre uma familiaridade e uma estranheza junto ao que nos diz o outro, o que nos leva sempre a perceber que a tradição não é uma unidade inquestionável e autoevidente, que pudesse ser naturalizada.

No ensaio A Incapacidade para o Diálogo que está presente na obra Verdade e Método II, Gadamer recoloca as questões que circundam todo o debate sobre a questão do desaparecimento do diálogo. É interessante observar que, nesse ensaio, Gadamer faz menção ao nome de Martin Buber, como um autor que, assim como Franz Rosenzweig, Friedrich Gogarten e Ferdinand Ebner, estivesse convencido de que o caminho da verdade passava pelo diálogo. (2002, p.247). 
Nesse ensaio, Gadamer também caracteriza algumas formas de diálogo: 1) Diálogo pedagógico: que facilmente resulta em um monólogo protagonizado pelo professor; 2) Diálogo de negociação: que ainda que não tenha um caráter de comunhão mútua entre pessoas e de transformação, ainda preserva a escuta, pela necessidade de se negociar interesses pessoais diversos; 3) Diálogo terapêutico: que representa o próprio processo de cura, quando se tenta reestabelecer para o paciente a comunicação que foi interrompida com o mundo circundante e 4) Diálogo à mesa: que se encontra em nítida extinção.

A primeira forma de diálogo caracterizada por Gadamer parece ser consoante ao que Buber considerou sobre o "dobrar-se-em-si-mesmo". Para ilustrar, Gadamer traz uma situação bastante emblemática protagonizada por Husserl e Heidegger em uma ocasião na Universidade de Freiburg na Alemanha:

Recordo-me de meu tempo de estudante de um seminário que fiz com Husserl. Sabemos que o exercício do seminário costuma conter o máximo de diálogo investigativo possível e o mínimo possível de diálogo pedagógico. Husserl, que nos primeiros vinte anos como mestre de fenomenologia em Friburgo sentia-se movido por um profundo impulso missionário e exercia na realidade uma atividade filosófica de ensino muito significativa, não era nenhum mestre do diálogo. Ele abria aqueles seminários com uma questão inicial, recebia uma resposta curta e movido por essa prosseguia seu monólogo por duas horas seguidas. Quando ao final da reunião saía da sala junto com seu assistente, Heidegger, dizia a este último: "hoje, sim, tivemos realmente um debate animado". (GADAMER, 2002, p. 248)

Numa visão buberiana, tamanha era a imersão de Husserl em seu monólogo, que, naquele momento, ele chegava a acreditar que havida de fato travado um debate com alguém, com um "Outro" ali presente. Contudo, o que de fato ocorria era que ele durante todo o tempo falou e ouviu somente a si mesmo.

Gadamer percebe que a própria maneira como as instituições de ensino se estruturam praticamente cria pouca possibilidade para o diálogo: "nas situações de ensino, quando esta ultrapassa a intimidade de um pequeno círculo, reside uma dificuldade intransponível para o diálogo" (GADAMER, 2004, p.248). Para Gadamer, não é, no entanto, por mero acaso que as instituições de ensino se estruturam dessa forma. Isso seria um reflexo do modo como o projeto educacional da Modernidade compreendeu o indivíduo e sua formação. 
O que melhor caracteriza a incapacidade para o diálogo, na perspectiva gadameriana, é a incapacidade de escutar o outro - algo que podemos experimentar em nós mesmos. Não ouvir honestamente o que o outro diz, ou simplesmente não ter a capacidade de ouvir o que dizem os outros, é algo que ocorre quando se está "constantemente ouvindo a si mesmo, [pois] quem possui os ouvidos tão cheios de si mesmo, buscando seus impulsos e interesses, já não consegue ouvir o outro" (GADAMER, 2004, p.251). Muitas vezes, diagnosticamos no outro a incapacidade para dialogar, mas na realidade isso ocorre justamente porque não estamos dispostos a nos abrirmos para uma escuta verdadeira, que coloque em jogo as nossas convicções. Nos termos de Buber, não tornamos o outro presente, não dizemos "Tu" ao outro e, com isso, privamo-nos de estabelecer uma relação verdadeira.

O que parece diferenciar os dois autores é a maneira como cada um aborda o diálogo. Buber privilegia a ação do sujeito e, por influência dos ensinamentos chassídicos, convoca-o a responsabilizar-se por si mesmo, pelo outro e por aquilo que realiza no mundo. Buber chega a diferenciar dois tipos de existência: a monológica e a dialógica. Segundo Buber: "Aquele que vive uma vida monológica nunca percebe o outro como [alguém] que, ao mesmo tempo, não é absolutamente ele próprio, mas com quem ele, assim mesmo, comunica-se." (2014, p.55).

Gadamer, por sua vez, não deixa de dar importância à ação do sujeito. Ele considera que a existência de um verdadeiro diálogo requisita a entrega de si, ou seja, uma abertura para uma transformação daquilo que se pressupõe ser. Contudo, por influência da fenomenologia hermenêutica, ele se ocupa na maior parte do tempo em descrever aquilo que nos acontece e nos condiciona. Como já falamos anteriormente, não é objetivo da hermenêutica de Gadamer, prescrever a ação do homem. Dizer como ele deve fazer para que um diálogo autêntico se efetue. O que está em questão para o autor é justamente elucidar aquilo que "ultrapassando nosso querer e fazer, nos sobrevém, ou nos acontece" (GADAMER, 1999, p.14).

Acreditamos ser relevante mencionar Buber, na medida em que ele é considerado um autor para quem o diálogo é um conceito central na reflexão sobre a ética. Assim como Gadamer, Buber sustenta que o diálogo é responsável pela mobilização histórica do mundo, desde que haja de fato uma construção conjunta 
entre os interlocutores. Entretanto, veremos a seguir que Gadamer, apesar de não refutar a concepção de diálogo em Buber, oferece uma abordagem mais radical do conceito, abordagem que transpõe o horizonte da ética para o da ontologia.

\title{
2.8. \\ Sobre as condições do diálogo: como ficam as tensões e os conflitos?
}

Não podemos perder de vista que existem objeções à ideia de que é por meio do diálogo que se torna possível a transformação de horizontes compreensivos e a inclusão do outro através da expansão de tais horizontes. Contudo, como observa Gil-Ferreira (2016), algumas dessas objeções se equivocam quando tomam como sendo objetivo do diálogo a busca por um consenso, o que resultaria facilmente em "um encobrimento das tensões e conflitos nas relações sociais" (informação verbal) ${ }^{20}$. Pelo menos no que se refere ao modo como a hermenêutica gadameriana compreende o diálogo, não é possível afirmar que o diálogo "atua para pacificar conflitos" (idem). Nas palavras de GilFerreira:

\begin{abstract}
Conflitos existem porque o horizonte histórico é ele mesmo dialógico, o que significa que os enfrentamentos com os outros tem o potencial de pôr a descoberto as insuficiências de ambos os horizontes. Gadamer não concebe o diálogo como uma maneira de pacificar conflitos por meio de um falso consenso imposto pelo opressor, ou pelo mais forte. Na realidade, Gadamer concebe o diálogo a partir do caráter dialógico constitutivo de todo horizonte. (GIL-FERREIRA, 2016)
\end{abstract}

Os preconceitos historicamente sedimentados constituem um conjunto de crenças que condicionam nossa posição em um horizonte, ao mesmo tempo em que estão eles próprios articulados a esse mesmo horizonte de significados. Atravessam os diálogos não somente os preconceitos que tendem a orientar nossas interpretações, mas também os preconceitos que tendem a orientar a interpretação que fazemos do outro e do que ele nos fala. Nós nos colocamos de diferentes maneiras na interlocução com diferentes pessoas e falamos sobre um mesmo tema de modos diferentes com cada uma delas, seja quando compartilhamos com elas um mesmo horizonte histórico, seja quando ela manifesta um pertencimento a outro horizonte histórico, o de outra cultura, por exemplo. Podemos ainda dizer

${ }^{20}$ GIL-FERREIRA. P.C. Golpismo e conservação: conflito de identidades ou identidade como conflito, in Congresso Sobre o Conceito de Golpe, UFRJ, Rio de Janeiro, 06 de julho de 2016. 
que, dependendo do nosso interlocutor, a modalidade da interlocução ganha um caráter diferente. Uma mãe não conversa sobre a morte com seus filhos pequenos do mesmo modo como ela fala sobre o assunto com sua própria mãe já idosa. Da mesma forma, essa conversa que uma mãe tem com sua filha não é a mesma que desenvolve com um médico. O mesmo pode ser dito da conversa de uma professora com seus alunos, pois cada aluno possui uma relação com seu horizonte histórico, cada um vem de um lugar diferente, de uma classe diferente, com suas peculiaridades linguísticas etc.

Disso se segue que não podemos simplesmente partir do pressuposto de que duas subjetividades isoladas dialogam em condição de neutralidade, ao invés disso, o que vemos são duas posições relativamente diversas em um horizonte histórico. Assim, não há como ignorar a tensão inerente a essa diferença. Negar a existência dessa tensão seria negar a própria alteridade do outro. Quando um adulto conversa com uma criança, ele reconhece a alteridade dela ao reportar-se a ela de modo diverso do que se reportaria a outro adulto. A diferença, portanto não é algo que se possa ou se deva desconsiderar. O problema, contudo, parece residir quando o horizonte de construção de sentido sobre determinado modo de ser encontra-se carregado de preconceitos que limitam ou enviesam a nossa relação com o outro de tal maneira que já não estamos mais abertos a ouvi-lo. Ou seja, quando estes preconceitos de antemão impedem uma relação de abertura no diálogo.

Quando consideramos, por exemplo, o que significa ser uma criança, ou um idoso, somos remetidos ao horizonte histórico em que esses significados se formam. Dessa maneira, podemos notar o quanto nossa compreensão está orientada por preconceitos que, em princípio, ditam nossa relação com esses interlocutores. Evidentemente o sentido do que é ser criança ou o que é ser idoso nos coloca novamente no horizonte histórico de construção desse sentido. Assim, carregamos em nossa compreensão os preconceitos que irão nos orientar, pelo menos a princípio, na relação com esse outro. Esses preconceitos, contudo, deverão ser passíveis de alteração no jogo dialógico que se estabelece. Isso de modo algum significa que já haja um entendimento pacífico, de antemão, ou uma condição de igualdade. Gadamer, por isso, considerou que existe uma distância entre crenças, tempos e pessoas que é irredutível. Todavia, essa distância não impossibilita o diálogo. Muito pelo contrário, é ela "que confere tensão e vida a 
todo compreender" (GADAMER, 2004, p.132), isso porque, "cada qual possui o seu próprio 'horizonte' e todo compreender representa uma fusão desses horizontes" (idem). A vinculação a um horizonte é o ponto de partida para a relação com o outro e não um limite que se impõe. Como observa Ricoeur em diálogo com a filosofia gadameriana:

Se restabelecemos a dialética dos pontos de vista e a tensão entre o outro e o próprio, chegamos ao mais elevado conceito (...) o de fusão de horizontes. Trata-se de um conceito dialético procedendo uma dupla recusa: a do objetivismo, segundo o qual a objetivação do outro se faz no esquecimento do próprio; e a do saber absoluto, segundo o qual a história universal é susceptível de articular-se num único horizonte. Não há horizonte fechado, pois podemos nos transportar para outro ponto de vista e para outra cultura. Seria uma robinsonada pretendermos que o outro seja inacessível. Mas não há horizonte único, pois a tensão do outro e do próprio é insuperável. (RICOEUR, 1977, p.115)

Evidentemente, num mundo em que existem desigualdades e conflitos de interesses, a diferença pode combinar-se ou confundir-se com a desigualdade, como bem caracteriza o pensador Boaventura de Souza Santos ${ }^{21}$. Nesse sentido, não é a diferença o que impede o diálogo, mas sim a existência de relações de força desiguais num campo social. Contudo, o problema que vemos emergir na busca pelo reconhecimento das diferenças e no combate das desigualdades seria o seguinte: em que medida é possível afirmar e reconhecer as diferenças, se não pelo diálogo?

Algo de que os movimentos que buscam afirmar as diferenças já se deram conta é que os indivíduos podem e devem falar por si mesmos sobre as questões que lhes dizem respeito, assumindo o protagonismo garantido por seus lugares de fala $^{22}$. Isto de modo algum constitui uma postura essencialista, uma vez que ela não deslegitima a fala daqueles que não pertencem aos grupos que se encontram em desvantagem de poder. Essa postura somente sublinha que existe uma diferença quando quem fala é o "outro" e prioriza a fala desse outro quando ele a reivindica. Como bem coloca, Djamila Ribeiro:

O falar não se restringe ao ato de emitir palavras, mas de poder existir. Pensamos lugar de fala como refutar a historiografia tradicional e a hierarquização de saberes consequente da hierarquia social. Quando falamos de direito à existência digna, à voz, estamos falando de locus social, de como esse lugar imposto dificulta a

${ }^{21} C f$. SANTOS, Boa Ventura de Souza. A gramática do tempo. Para uma nova cultura política. São Paulo: Cortez, 2006.

${ }^{22} C f$. RIBEIRO, Djamila. O que é lugar de fala?. Belo Horizonte: Letramento, 2017. 
possibilidade de transcendência. Absolutamente não tem a ver com uma visão essencialista de que somente o negro pode falar sobre racismo, por exemplo. (RIBEIRO, p.37, 2017)

Reivindicar essa fala, contudo, requer a superação dos constrangimentos que a ela se impõem. Constrangimentos esses que podem dizer respeito inclusive, ao uso de variedades linguísticas. Como bem observou Marcos Bagno em sua famosa obra Preconceito Linguístico, quando se condena uma variedade linguística, silencia-se grupos inteiros de pessoas. Isso porque cada variedade linguística é o modo de expressão de um grupo, de uma comunidade linguística. A língua é mais do que mero instrumento de comunicação, ela é o modo como se estrutura e se manifesta toda a compreensão de mundo de um indivíduo. Como o próprio autor afirma "a língua varia tanto quanto a sociedade varia. Existem muitas maneiras de dizer a mesma coisa e todas correspondem a usos diferenciados e eficazes dos recursos que o idioma oferece a seus falantes" (BAGNO, 2003, p.18).

Bagno reconhece que existe hoje na sociedade uma forte militância contra os mais diversos preconceitos que estão na base de variadas formas de discriminação social. Contudo, Bagno defende que o preconceito mais comum e que nos atravessa cotidianamente, que é o preconceito linguístico, ainda é pouco discutido. Muito pelo contrário esse tido de preconceito tem sido alimentado a cada vez em que se tenta, inclusive através dos meios de comunicação, se ensinar o que é "certo" e o que é "errado" no uso da língua.

Por vezes, uma das justificativas que se coloca para tal postura é o receio de que cada grupo adote sua própria variedade linguística e se isole nela, tornando-se com o tempo cada vez mais difícil a comunicação entre os grupos. A preservação da língua também seria a preservação da possibilidade de comunicação entre os indivíduos num país tão diverso e complexo como o nosso. Contudo, tomando como exemplo a Alemanha, vemos que quando ela passou pelo seu processo de unificação, o alto alemão foi instituído como a língua oficial. Isso, no entanto não impediu e não impede que cada região preserve seus dialetos. No acaso do Brasil, como isso acontece? Temos uma língua oficial e, ao mesmo tempo, em cada região encontramos variações dessa língua e, ainda, dentro de cada região, observamos variações que ocorrem entre grupos etários, identitários e de perfis econômicos diferentes. $\mathrm{O}$ que permite que esses grupos continuem sendo capazes de se comunicarem uns com os outros entre eles é a participação em um horizonte 
comum mais amplo. Todos se encontram, de um modo ou de outro, inseridos em uma tradição e delas compreendem e compartilham seus valores. Essa aproximação, contudo, pode se dar em diferentes níveis. Por mais que seja possível estabelecer um diálogo e que a vivência em uma mesma língua facilite essa aproximação, haverá sempre alguns pontos em que a distância entre um e o outro será intransponível. Essa distância é o que confere tensão ao diálogo.

Contudo, considerando que as desigualdades sociais são inegáveis e que, por conseguinte, elas colocam os interlocutores em condições desiguais de força já de partida, como é possível superar tal situação? Como é possível abrir espaços que antes não existiam ao mesmo tempo em que se reivindica que as condições de igualdade se estabeleçam? Existe assim um grande problema a ser enfrentado: Como é possível estabelecer um diálogo com quem está com os ouvidos cheios de si mesmo? Essa é uma pergunta para qual é difícil de encontrar uma saída pacífica. Entretanto, quando nos damos conta de que os termos do diálogo precisam ser restabelecidos, a fim de que se tenha um verdadeiro diálogo, como é possível que isso se dê sem que algum diálogo se estabeleça a princípio, ou seja, sem que exista a "violência da iniciativa" (GIEGEL apud GADAMER, 2004 p.311)? Mesmo lá onde as condições para o diálogo não são as mais favoráveis, como se requisita que elas sejam favoráveis? Não é através do diálogo? Nesse sentido, Gadamer diz:

Não consigo ver como no âmbito social a competência comunicativa e seu domínio teórico possam derrubar as barreiras que há entre os grupos, que numa crítica mútua acusam o caráter coercitivo do acordo existente no outro. Nesse caso parece ser indispensável "a violência da iniciativa" (Giegel, 249) e com ela o postulado de uma competência totalmente diferente, ou seja, a da ação política, com o objetivo de possibilitar a comunicação onde ela não existe. (GADAMER, 2004, p.311)

Esta é a resposta que Gadamer dá às críticas que recebeu de um de seus parceiros de diálogo, o filósofo Jürgen Habermas. Para Habermas, a racionalidade e a autorreflexão são parâmetros que devem ajudar qualquer indivíduo a superar seus contextos de vida e fazer uma avaliação justa em qualquer situação. A crítica direcionada a Gadamer é a de que a hermenêutica "bate de dentro nas paredes do contexto da tradição; logo que estes limites são experienciados e conhecidos, ela não pode mais absolutizar tradições culturais." (HABERMAS, 1987, p. 21), o que culminaria num "irracionalismo" ou um "idealismo relativo". 
Diante disso, Gadamer avalia que a pretensa ideia de ver "a partir de fora" acaba por dissimular o que de fato ocorre: uma tomada de posição a partir daquilo que já de antemão lhe parece justo uma vez que essa medida é dada pelos preconceitos fornecidos pela nossa tradição na qual nos inserimos. Desse modo, num contexto global de encontro entre diferentes culturas, não podemos acusar de cegueira aquele que não vê o mundo a partir dos parâmetros da racionalidade moderna. Muito embora nosso ideal de justiça e democracia se funde nesse paradigma e a sociedade ocidental e ocidentalizada se guie por ele, não podemos perder de vista que nem todas as sociedades se orientam por tais preconceitos em seu foro mais íntimo. Assumir nosso vínculo histórico não deve ser um problema, mas o caminho para que um diálogo verdadeiro possa existir. À política, nesse sentido, cabe o papel de buscar reciprocidade justamente por reconhecer tais diferenças e por compreender que o outro não nos é absolutamente inacessível e que nós também não somos inacessíveis para o outro. Gadamer compreende "arte política como uma espécie de arte têxtil que permite compor com o oposto numa unidade" (GADAMER, 2004, p.356). Por esse motivo afirma que:

As oposições insuperáveis entre grupos sociais e políticos repousam na diferença de interesses e na heterogeneidade das experiências. (...) Falar de cegueira nesse caso pressuporia a posse exclusiva da convicção correta da verdade. Afirmar isso, sim, seria um tipo de cegueira. A hermenêutica, por outro lado, parece-me continuar tendo razão quando, em favor do verdadeiro sentido da comunicação, sustenta que os preconceitos devem ser checados no confronto mútuo e quando mantém essa reciprocidade (...). (GADAMER, 2004, p.312)

Sobre o diálogo entre Habermas e Gadamer, Paul Ricoeur ainda observa que, ao pressupor ser possível nos colocarmos para além de nossas determinações históricas, Habermas criou ao mesmo tempo dois problemas: 1) o de que seria possível preservar uma razão imaculada, para além dos vínculos históricos e 2) o de que seria possível tomar a história como um objeto em si.

A questão que permanece consiste em saber se o ideal de uma comunicação sem limites e sem coação, que Habermas opõe ao conceito de tradição, escapa ao argumento de Gadamer: a ideia de conhecimento acabado da história é impensável bem como, ao mesmo tempo, a de um objeto em si da história. (RICOEUR, 1977, 117)

A impossibilidade de fixar uma racionalidade absoluta e ao mesmo tempo fixar a história como objeto é o que faz com que os significados estejam sempre 
em disputa e que na relação com o outro alcancemos um conhecimento sobre ele e sobre nós mesmos:

Dessa relação com o próprio e com o outro o conceito de preconceito recebe seu último toque dialético: é na medida em que me transponho para o outro, que me descubro a mim mesmo, com meu horizonte presente, com meus preconceitos. (RICOEUR, 1977, 116)

Enquanto Gadamer quer pensar a abertura da história com o conceito de diálogo, Habermas parece crer que é preciso submeter a história a uma determinada concepção moral. A história deve ser projetada tendo em vista um paradigma que se funda, em última análise, em uma moralidade. Contudo, na medida em que o outro não é objetificável, as diferenças não se impõem como um objeto de conhecimento já acabado, algo que também tem sido fruto de discussões entre diferentes correntes dos estudos multiculturais. Assim, o diálogo pensado a partir da noção de fusão de horizontes pode se relacionar, em certa medida, com o debate sobre o multiculturalismo. Em um país como o Brasil, com tanta diversidade étnica e cultural, esse tipo aproximação pode ser interessante.

De forma bastante introdutória, podemos pensar aqui a respeito da formulação de Sergio Costa, que considerou ser possível, a partir da ideia de indivíduo, agrupar metodologicamente em duas correntes, diferentes concepções de multiculturalismo ${ }^{23}$. A primeira corrente, que seria a dos multiculturalistas comunitaristas, considera que o indivíduo, ou o self, que se constitui dentro dos grupos aos quais pertence e dos quais retira e significa para si de tradições e repertórios culturais, sem que, na maioria das vezes, se dê conta disso. O pertencimento cultural desses indivíduos se dá em duas vias: o indivíduo pertence a um grupo, na medida em que reconhece nele seus valores e sua maneira de ser e, ao mesmo tempo, esse grupo pertence ao indivíduo, na medida em que ele é parte constitutiva daquilo que ele é. Assim, grupos e indivíduos se alteram de forma dinâmica, um transformando o outro na medida em que um significa o outro. Para a segunda corrente multicultural, que seria a dos liberais, o indivíduo poderia colocar diante de si tradições e repertórios culturais, julgar sua legitimidade e a partir de uma reflexão racional deliberar acerca de seu pertencimento.

\footnotetext{
${ }^{23}$ Reconhecemos a amplitude do debate acerca das diversas correntes dos estudos multiculturais e os diferentes aspectos que as distingue umas das outras. O aprofundamento dessa questão nos requisitaria um maior diálogo com diferentes autores, algo que escaparia aos objetivos desse trabalho.
} 
Em ambas as correntes, Sérgio Costa observa a existência de um "núcleo autêntico e genuíno" (2009, p.53), algo com o que Stuart Hall e Homi Bhabha parecem ter conseguido romper com a concepção de um 'sujeito descentrado'." (COSTA, 2009, p.43).

Essa concepção, defende que o sujeito escapa a qualquer possibilidade de teorização e que não há realidade anterior ao discurso. $\mathrm{O}$ que evidentemente, a partir de uma crítica hermenêutica, nos remete já de início a algumas questões: O discurso, por si só não carrega consigo toda a tradição na qual ele se dá? Caso contrário, como nos faríamos entender uns com os outros? Será que é mesmo possível, alterar o caráter das coisas a cada momento alterando os discursos? Mas, ao mesmo tempo, essa tradição existe para além das narrativas? Até que ponto ela é passível de ser rearticulada e transformada dentro de um horizonte histórico?

Para Sérgio Costa, uma contribuição importante da crítica pós-estruturalista às duas vertentes, que ele identifica no multiculturalismo, é favorecer o debate a cerca da possibilidade de uma representação política das diferenças:

Conforme se mostrou, para autores como Hall e Bhabha, o momento de representação da diferença é, ao mesmo tempo o momento de construção, vale dizer, de articulação dessa. Não existe, na leitura pós-estruturalista, um ente social anterior à representação e que emergisse publicamente, em algum momento, para realizar uma presumida vocação publica imanente. Discursos e sujeitos constitui-se simultânea e mutuamente. (...) Nesse sentido, a representação institucionalizada da diferença pretendida pelas políticas multiculturalistas significa o aprisionamento e congelamento de algo - a diferença que só pode ser móvel, flexível e variável. (...) qualquer intervenção do estado refaz o mapa das negociações identitárias, inventando literalmente novos grupos socioculturais. (COSTA, 2009, p.54)

Costa, contudo, conclui que "se revestidas de tal cuidado, as políticas multiculturalistas podem ser bem vindas" (idem) uma vez que "a intervenção corretiva do Estado torna-se desejável e necessária" (idem) diante das desigualdades. Em alguma medida, a hermenêutica gadameriana parece se aproximar das críticas pós-estruturalistas aqui apresentadas por Sérgio Costa, uma vez que Gadamer afirma que:

No espelho da linguagem reflete-se, antes, tudo que é. Nele e somente nele encontramos o que não encontramos em parte alguma, porque somos nós mesmos (e não apenas o que pensamos e sabemos acerca de nós mesmos). No fundo, a linguagem não é nenhum espelho, e o que vemos nela não é reflexo de nosso ser nem do ser de todos, mas uma interpretação e revitalização do que existe conosco, tanto na dependência real de trabalho e dominação como em tudo mais que constitui nosso mundo. (GADAMER, 2004, p.283) 
Uma vez que a "linguagem é um jogo em que todos participamos" (idem), não é possível concebê-la como um sujeito anônimo passível de contemplação. Desse modo, discursos e sujeitos parecem de fato e constituírem de forma simultânea e mútua. Contudo, Gadamer ao dar um acento especial aos preconceitos que herdamos da tradição, que condicionam nossa compreensão - e consequentemente nossa linguagem - e que somente se revelam na distância temporal, mais uma vez, o espaço para a transformação parece, a princípio, novamente limitado. Uma vez que nesse jogo, jogamos com os sentidos que nossa inserção em uma tradição nos fornece, por mais que algo de novo se revele esse novo já nasce dentro de uma circularidade que nos permite retomar às suas origens.

Retomaremos a essa questão na segunda parte desse trabalho, quando nos dedicarmos mais atentamente às criticas de Gadamer ao modo de ordenação do mundo, onde se insere também os reflexos do tecnicismo científico no âmbito social.

Para finalizarmos essa primeira parte do trabalho, traremos aqui mais um elemento do espectro da filosofia gadameriana: uma releitura de Platão sob um ponto de vista da hermenêutica dialética. Nossa intenção é apresentar, nesse ponto, como uma interpretação mais comum sobre o saber do mestre e do aluno, altera-se de modo radical quando deixamos de vê-la sob o paradigma das subjetividades.

\section{9}

\section{A retomada de Platão em Gadamer}

Embora Gadamer seja mais conhecido por sua identificação com a hermenêutica heideggeriana do que por seus estudos sobre os gregos, ao abordarmos mais atentamente a filosofia gadameriana, percebemos que a influência do pensamento grego possui um caráter decisivo. Exatamente por conta disso, não encontramos em Gadamer aquela leitura amplamente cristalizada, que costuma classificar Platão como um pensador idealista e Aristóteles como realista, como observou Rohden (2018, p.12). O encontro de Gadamer com Heidegger, como vimos na introdução deste trabalho, dá-se sob o signo dos estudos sobre os pensadores clássicos gregos que despertavam o interesse de ambos. Como vimos 
anteriormente, não foi senão a partir da leitura de Heidegger sobre Aristóteles, leitura muito influenciada pelas descobertas da fenomenologia de Husserl, que Gadamer encontrou, por seu turno, um ponto de convergência entre Platão e Aristóteles no campo daquilo que ele denominou como "filosofia prática". Gadamer afirma ter se dedicado ao longo de décadas a essa questão, sobretudo durante suas atividades de ensino, nas quais tinha a oportunidade de elaborar e experimentar o que ele denominou como sendo uma "unidade eficaz platônicoaristotélica" (GADAMER, 2009, p.4).

Gadamer, no entanto, discorda da leitura heideggeriana de Platão que considera que este representaria "o passo decisivo em direção ao esquecimento do Ser do "pensamento metafísico"” (idem) e assume ter tentado vencer teoricamente esse desafio ao longo de sua obra Verdade e Método I. Nesse sentido, não é exagero afirmar que toda a hermenêutica gadameriana foi tramada com a filosofia dialética de Platão a partir da filosofia contemporânea, como percebe Rohden (2018, p.18).

Reconhecendo a importância da filosofia grega para a educação, a nova visão possibilitada pela leitura de Gadamer mostra-se de extrema importância para a nossa pesquisa, uma vez que ela busca nos libertar de interpretações enviesadas, livre das quais, o pensamento grego ganha um novo fôlego.

O que Gadamer nos incentiva a fazer com relação a Platão é que nós nos orientemos pelo que ele nos diz, ao invés de adotarmos a estratégia hermenêutica clássica de interpretar os textos a partir da reconstrução das condições históricas em que ele foi escrito ou de buscar na subjetividade do autor o sentido de sua obra. Ele nos leva a um exercício hermenêutico de interpretação, de nos colocarmos em acordo com o que nos diz a obra e o que ela pode ainda carregar de verdadeiro naquilo que apresenta.

\subsection{1}

\section{A Alegoria da Caverna sob uma perspectiva gadameriana}

Escrita por Platão por volta da década de 380 a.C., a narrativa da Alegoria da Caverna encontra-se no livro VII de A República, na qual Sócrates, em diálogo com Gláucon, descreve uma caverna subterrânea que possui uma extensa abertura para a luz do dia. Dentro desta caverna moram homens que vivem presos ali desde 
a infância, amarrados pelas pernas e pelo pescoço, de tal modo que eles só conseguem olhar para frente. Os moradores da caverna estão de costas para a saída e, atrás deles, existe um muro que serve como uma espécie de biombo utilizado no teatro de marionetes. Fora da caverna há uma fogueira. Entre a fogueira e a entrada da caverna existe um caminho por onde passam pessoas carregando vários objetos: estatuetas de homens e de animais feitas em pedra e madeira. A fogueira faz projetar na parede do fundo da caverna, a sombra desses objetos, que são carregados pelas pessoas que estão fora da caverna e ultrapassam a altura do muro. Tudo o que os prisioneiros conseguem ver, então, são as sombras de tais objetos projetadas na parede a sua frente. As pessoas que passam lá fora, por vezes conversam entre si. A voz dessas pessoas ecoa dentro da caverna e com isso os prisioneiros julgam estar ouvindo a fala das sombras.

Após a descrição da situação na caverna, Sócrates pede que Gláucon imagine, então, que um desses prisioneiros fosse levado para fora da caverna. O que aconteceria com esse prisioneiro, no entendimento de Sócrates, seria que, a princípio, ele teria os olhos ofuscados pela luz, sentiria dor e dificuldade em fixar os objetos cujas sombras via antes. Em seguida, poderia duvidar da realidade de tais objetos, uma vez que por muito tempo acreditou que as sombras fossem reais. Ele talvez desejasse voltar e se esconder na caverna com os olhos doloridos e ficasse aborrecido com quem o forçou a ir para fora dela. O prisioneiro precisaria de tempo para se acostumar com a luz e se tornar apto a ver os objetos:

Em primeiro lugar olharia mais facilmente para as sombras, depois disso, para as imagens dos homens e dos outros objetos. A partir de então, seria capaz de contemplar o que há no céu, e o próprio céu, durante a noite, olhando para a luz das estrelas e da Lua, mais facilmente do que se fosse o Sol e o seu brilho de dia. (PLATÃO, 2001, p. 317)

Ainda no entendimento de Sócrates, o prisioneiro veria, então, que o Sol é que produz as diferentes estações do ano e a própria sucessão dos anos, que ele reina sobre tudo o que há no mundo visível e que é a causa de tudo o que os seres humanos podem contemplar. Ao lembrar-se de sua antiga morada, das coisas que lá havia e de seus companheiros de prisão, o antigo prisioneiro ficaria feliz com a mudança e não desejaria mais voltar a viver na caverna. Mesmo que houvesse entre os habitantes da caverna honras e distinções para premiar aqueles que melhor distinguissem as sombras e fossem capazes de prever quais viriam antes e 
quais viriam depois, ainda assim, o homem que saiu da caverna não desejaria nela voltar a permanecer.

Gláucon concorda com as suposições de Sócrates, que pede para que ele imagine, então, que o prisioneiro voltasse para seu antigo lugar e pergunta: "Não teria seus olhos cheios de trevas ao regressar subitamente da luz do sol?" (PLATÃO, 2001, p.318). Isso poderia levá-lo ao ridículo ao tentar rivalizar com os outros cativos, pois por algum tempo ele não seria capaz de ver nada nas sombras. Os outros prisioneiros poderiam dizer que ter ido para a luz the arruinou os olhos. Caso o antigo prisioneiro ainda tentasse livrar aqueles homens das trevas, correria o risco de ser morto por eles.

Sócrates afirma em seguida que "as perturbações visuais são duplas, e por dupla causa, da passagem da luz à sombra, e da sombra à luz.” (2001, p.320) e que o mesmo se passa com a alma. Quando ela se encontra perturbada e incapaz de ver, pode estar ofuscada por falta de hábito "por vir de uma fase mais luminosa, ou (...) por vir de uma maior ignorância a uma luz mais brilhante". Desse modo, Sócrates pondera: "se é verdade o que dissemos: a educação não é o que alguns apregoam que ela é. Dizem eles que introduzem a ciência numa alma em que ela não existe, como se introduzissem a vista em olhos cegos.” (PLATÃO, 2001, p.320)

A Alegoria da Caverna é com frequência usada na educação para exemplificar a ideia de que, na relação de ensino e aprendizagem, o professor seria aquele que está na luz e o aluno aquele que está no escuro. O professor por já ter aprendido a verdade, por já ter visto o mundo sob a luz do Sol, vai até o aluno, que a princípio oferece alguma resistência, mas que depois aceita segui-lo até a luz. A luz é entendida como sendo a verdade, o conhecimento verdadeiro. Essa leitura seria, contudo, uma leitura apressada do que Platão teria apresentado na Alegoria. Para Gadamer:

Diante dessa grandiosa e multifacetada parábola da caverna, prescindimos de submetê-la a uma exegese epistemológica precisa, voltando nossa atenção para um ponto apenas, a função assumida pela parábola dentro do desenrolar do diálogo. Agora, ela é totalmente inequívoca: cabe-lhe disseminar a aparência, segundo a qual a dedicação à "filosofia" e à vida "teórica" seria, em geral, incompatível com a prática política na sociedade e no Estado. O tema é o ofuscamento sofrido por quem está habituado à escuridão e passa a ser exposto à claridade e, inversamente, por quem sai da claridade e caminha rumo à escuridão. Cabe-lhe explicar porque os indivíduos envolvidos na vida prática não dão a mínima importância à vida teorética: 515d 516e. A alegoria procura esclarecer essa suposta inaptidão "teórica" 
do ser humano para a prática. Não faz mister apenas adaptar-se à claridade, mas também à escuridão: também aquele que retornasse do dia real à penumbra da caverna submeter-se-ia, em primeiro lugar, a um ofuscamento devido ao contraste com a claridade. Não significaria nenhuma cegueira ou incapacidade real encontrar orientação ali. O ofuscamento rapidamente dissipar-se-ia. (GADAMER, 2009, p.77)

O que Gadamer defende é que na Alegoria da Caverna o conhecimento, o saber, o pensar está na dialética. De acordo com Gadamer, a questão central para Platão na Alegoria da Caverna está em mostrar que é na dialética que está a possibilidade do saber, que essa possibilidade não está somente na luz do conhecimento verdadeiro e nem tão somente na sombra. O que Platão estaria tentando mostrar é que é na flutuação entre sombra e luz, que o conhecimento se dá. O saber estaria nessa confrontação, de enxergar o seu escuro e se guiar até o seu claro, de enxergar o seu claro e se deixar guiar até o seu escuro. O procedimento sofístico se reduziria a se aferrar ou às sombras, negando a existência da luz, isto é, do conhecimento verdadeiro. ou a sua própria luz, denunciando as sombras alheias. O conhecimento, portanto, estaria no diálogo entre os dois. Nas palavras de Rohden:

(...) o caminho de saída e o de retorno à caverna institui um elo no qual eles se entrecruzam e instituem uma circularidade (entre os dois caminhos). Nem a dialética propriamente dita e menos ainda seu método são unidirecionais segundo a lógica linear progressiva. O método da dialética é tecido pela articulação tensional entre o plano conceitual e o prático passível de ser elevado ao grau metafórico do conhecido movimento cardíaco da diástole e da sístole. (ROHDEN, 2018, p.118)

A mesma alegoria serviria tanto para pensar a relação entre o professor e o aluno, quanto para pensar "o conhecer" e "o não conhecer" que pode se realizar na mesma pessoa, e que, para Platão, estabelece-se no pensamento, no "diálogo interno da alma consigo mesma". Seria uma simplificação muito grande pensar que a Alegoria pretende estabelecer uma relação dicotômica afirmando que na práxis só existe escuridão e na teoria é que está a luz, Ou que na vida cotidiana, na vida dos afazeres cotidianos, o que há é só escuridão, enquanto que na vida teórica, na vida afastada e contemplativa, está a luz. Para Gadamer, o exercício dialético de Platão "não cria nem sustenta uma esquizofrenia entre a atividade teórica e a vida prática, pelo contrário, estimula o entrelaçamento circular virtuoso entre ambos." (ROHDEN, 2018, p.202). 
Com frequência ouvimos, no campo da educação, principalmente de quem está atuando majoritariamente dentro de sala de aula que aquilo que se experimenta conceitualmente sobre a educação, nos textos e nas reflexões dos autores, dialoga pouco com o que se vivencia dentro das escolas. Existe o entendimento de que o cotidiano das escolas é muito diferente das discussões acadêmicas e que as teorias pouco contribuem num nível prático. A leitura de Platão a respeito do que se dá nesse movimento de ir e voltar à caverna, sob uma perspectiva hermenêutica, pode nos ajudar a pensar sobre o que nos acontece. Uma vez que a dialética não pressupõe uma cisão entre mundo das sombras e mundo das ideias, ou seja, entre os princípios e as práticas, vemos nela a necessidade de exercício dessa capacidade de construir uma trama contínua entre teoria e prática. Dito de outro modo, caberia tanto a quem tende a aferrar-se à prática, quanto àquele que dela pouco conhece, o exercício de enxergar fora de suas cavernas. Uma prática bem-sucedida desse exercício abriria a possibilidade de diálogo entre vida prática e teórica, gerando uma "unidade tensional e complementar" nos termos em que explicita Rohden:

(...) ao analisarmos nossas práticas filosóficas, nos damos conta de que percorremos os caminhos de subida e de descida quase que concomitantemente. Normalmente, é por causa de uma espécie de dúvida ou se insight sobre algum tema ou problema que encetamos o caminho da subida ao nos dedicarmos a estudar a história da filosofia a fim de construirmos conceitos que lhes sejam apropriados. Por outro lado, a aquisição de mais clareza e consciência conceitual nos leva a fazer comparações com a realidade e, consequentemente, instaurar uma prática mais filosófica. Porém os dois movimentos são inseparáveis e compreendem-se numa unidade tensional e complementar. (ROHDEN, 2018, p.119 e 120)

Podemos aqui, mais uma vez, chamar a atenção para a dicotomia que se cria na Aufklärung: a de que na tradição o que há são preconceitos limitadores e de que somente no cultivo da racionalidade, concebida como um processo de autoesclarecimento é que se poderia sair da escuridão. Essa é também a crítica que Gadamer faz a noção de maioridade na Aufklärung. A noção de que em um dado momento, podemos sair de um estado heterônomo e alcançar um estágio de autossuficiência que o uso livre da razão permitiria. A partir do uso livre, deixaríamos para trás toda a heteronomia, ou seja, a tendência de apoiarmo-nos não só na tutela do outro, mas nos conhecimentos da tradição, para guiarmo-nos somente por nós mesmos. Isto é algo que para a Aufklärung tornou-se inclusive um projeto de sociedade: um coletivo de indivíduos completamente autônomos 
com relação à tradição, o que para a hermenêutica é uma completa impossibilidade. Em termos gadamerianos, isso significa que "quem sai à busca dos conceitos carrega consigo os pré-conceitos; quem se envereda na compreensão do princípio ou das coisas mais importantes leva, na garupa, aquilo que aprendeu na tradição" (ROHDEN, 2018, p.203).

A análise de Gadamer sobre a Alegoria da Caverna subverte uma leitura apressada da relação pedagógica e nos leva a pensar essa relação como uma fusão ao invés de uma transição. A educação ou a aprendizagem é pensada muitas vezes, de um modo cognitivista, como uma transição do não saber para o saber, ou uma transição da heteronomia para a autonomia. Mas a ideia para Gadamer é outra, é a de pensar na educação como uma fusão. A identidade daquele que sabe, ou a identidade do conhecimento não é uma identidade pronta. Quando pensamos na fusão, pensamos numa ignorância inerente ao saber. Essa identidade do mestre é uma identidade provisória. Nunca chegamos a um conhecimento pleno sobre nada, aquilo que sabemos não é algo acabado em si. E, também não existe progresso, num sentido de acúmulo de conhecimentos. Tudo o que conhecemos modifica o todo daquilo que já era conhecido. 


\section{3 \\ A experiência educacional}

Apresentamos até o momento os conceitos fundamentais da filosofia gadameriana com os quais trabalharemos na segunda parte deste estudo. Pretendemos nessa segunda parte, lançar mão desses conceitos dentro do debate de fenômenos pontuais que nos dispomos a interpretar. Continuaremos perseguindo o objetivo inicial de nosso estudo, que é o de problematizar como se forma uma razão crítica, da qual fala Gadamer, capaz superar os inumeráveis preconceitos ilegítimos que herdamos de nossa tradição.

Iniciaremos voltando ao contexto em que se insere nosso questionamento, que é o da democratização do acesso às instituições de ensino no nosso país e a compreensão de que hoje a escola atende a um público que anteriormente não atendia. Um público que traz consigo as diferenças com as quais o modelo tradicional de escola parece não conseguir dialogar. Algo que faz com que a crise na educação, que vem sendo compreendida como um fenômeno mundial, ganhe uma configuração bastante específica no Brasil. Problematizaremos duas tendências que facilmente identificamos nos debates no campo da educação hoje e buscaremos localizar de que maneira é possível inserir nossa contribuição. Em seguida, retornaremos, então, a Gadamer e sua crítica ao modo como se tem pensado a organização política e econômica em escalas mundiais e como isso se reflete no modo como lidamos com as diferenças. Por fim, iremos apresentar um caminho possível para uma formação hermenêutica que propicie a fusão e ampliação de horizontes compreensivos e que nos permita também reconhecer e valorizar os elementos que tornam tal formação possível. Entendendo que devemos nos manter afastados das pretensões instrumentalistas, procuraremos ao mesmo explicitar o caráter formador e transformador da própria experiência educativa. 


\section{1. \\ O questionamento da tradição: uma breve incursão na crise contemporânea da educação no contexto brasileiro ${ }^{24}$}

Se aquilo que temos chamado de tradição constitui uma herança de saberes que não se conserva sem rupturas, portanto, se devemos mais adequadamente falar em tradições em contínua transformação, isso significa que a defesa da escola, enquanto instituição tradicional, corroboraria um mero tradicionalism Estaríamos caminhando para o fim da escola, na medida em que observamos a crise de uma determinada tradição? Constantemente ouvimos a afirmação de que a educação se encontra em crise e que essa crise se tornou mais evidente, ou até mesmo se agravou, com a democratização do ensino no nosso país. Isto significa uma falência do modelo "tradicional" de educação escolar? Isto significa que, em uma sociedade como a nossa, a escola pode perder sua legitimidade e deixar de existir? Estamos caminhando para isso?

Como bem contextualiza Canário (2006) - em seu famoso livro: A escola tem futuro? Das promessas às incertezas - o século XX foi um período em que a educação escolar alcançou o seu triunfo. $\mathrm{O}$ que deu suporte à institucionalização do ensino foi, em grande medida, a maneira como a Aufklärung associou a necessidade de desenvolvimento da razão à educação ${ }^{25}$. A promessa de que o desenvolvimento da razão levaria toda a humanidade também ao seu desenvolvimento criou um ambiente propício para que a instituição escolar crescesse e se difundisse. A expansão do ensino, no entanto, por mais que tenha possibilitado um maior desenvolvimento científico e tecnológico, não alcançou o mesmo êxito nas questões sociais, sobretudo em países com profundas desigualdades sociais. Como observa Canário:

\footnotetext{
${ }^{24}$ Não consideramos produtivo, para os fins desse trabalho, uma apresentação maior dos problemas encontrados no contexto da educação brasileira. Partimos do entendimento de que tais problemas, que são de diversas ordens, têm sido objeto de inúmeras pesquisas e já se encontram detalhados em vasta bibliografia no campo educacional.

25 É importante observar que mesmo no contexto europeu, sobretudo na Alemanha, a universalização das instituições de ensino não se deu como uma consequência imediata ao movimento da Aufklärung. Logo após ter experimentado um desenvolvimento intelectual promissor no reinado de Frederico II, a Prússia enfrentou um período bastante nebuloso, sob o governo de Guilherme II. Nesse período, até mesmo Kant teve textos censurados (Britto, p.224, 2012). Foram necessárias ainda uma série de transformações de ordem política e social, que vieram somente no reinado de Guilherme III, para que a Alemanha começasse a adotar uma pedagogia neo-humanista favorável à "autonomia individual e independência dos sistemas de ensino" (idem). Cf. BRITTO, Fabiano de L. Identidade Cultural e Formação Individual: a Alemanha do século XIX e a Fundação da pedagogia mederna. Educação \& Sociedade, Campinas, v. 33, n. 118, p. 217-233, jan.-mar. 2012.
} 
Verifica-se que há um desequilíbrio acentuado entre o conhecimento científico e técnico que marca as nossas sociedades, por um lado, e, a imaturidade social e política, por outro, expressa na incapacidade de controlar os efeitos indesejáveis do progresso. (CANÁRIO, 2006, p.12)

A realidade não confirmou a promessa de desenvolvimento e progresso da Aufklärung, sobretudo no que se refere às questões sociais. O enorme avanço tecnológico que a humanidade alcançou não resultou necessariamente em melhoria de vida para a população em geral. Mesmo as sociedades mais escolarizadas e que desfrutam de um maior desenvolvimento tecnológico não deixam de produzir desigualdades e injustiças.

Não é possível, no entanto, imaginarmos que nossa sociedade estaria melhor sem os avanços tecnológicos que a difusão do ensino escolarizado propiciou. O que podemos nos perguntar, a partir disso, é como ainda é possível enfrentar o que Canário chamou de "efeitos indesejáveis do progresso" e buscar ainda algum equilíbrio que garanta mais justiça e igualdade.

O descontentamento com as promessas não realizadas com a escolarização fez com que a ideia de "crise" crescesse. No contexto brasileiro, quando se discute possíveis saídas para essa crise, duas tendências são facilmente identificáveis e apontam para caminhos opostos: 1) A primeira tendência, de caráter dogmático-tradicionalista, acredita que a saída está em se exigir maior rigor dentro das instituições de ensino, algo que se traduz pela busca por mais avaliações, mais cobranças, mais metas, emprego de bonificações etc.; e, na outra ponta, 2) A segunda tendência, que podemos denominar como cético-disruptiva, que defende nada menos do que o fim da escola, ou, mais especificamente, o fim do modelo de instituição escolar que conhecemos. Busquemos, então, compreender o que significa cada uma dessas duas tendências, começando pela segunda.

Para alguns estudiosos, como Ivan Ilich (1971) e Tião Rocha (2015), superar o modelo de educação vigente só é possível com o fim da própria escola. Rocha, inclusive, empreende seu próprio projeto de educação sem escola e o defende de forma apaixonada:

Escolarização e educação não são sinônimas, são coisas distintas, que muitas vezes têm caminhado inclusive de forma contrária. A educação é um processo que abre, que areja, que possibilita a aprendizagem, enquanto a escolarização fecha em uma 
grade, num currículo, com uma lógica cartesiana, visando o diploma. (ROCHA apud MOSÉ, 2015, p.271).

Diante dessa perda de sentido do conhecimento escolar, passa a existir "um desejo recorrentemente manifestado de "ligar a escola à vida"' (CANÁRIO, 2006, p.13). Um desejo de se relacionar com o conhecimento que parta da premissa de que nós já nos encontramos em relação com as coisas e que já temos informações sobre elas antes mesmo de as tomarmos intencionalmente como objeto de conhecimento. Assim, há uma urgência na busca de se superar a "forma escolar" que, ao tentar compartimentar o conhecimento em currículos, disciplinas, horários, métodos e avaliações, acabou por deixar escapar a relação que este estabelece com a vida.

No mesmo caminho, projetos como o da Cidade Educadora ${ }^{26}$, começam a trazer a intenção pedagógica para fora da escola reconhecendo que os indivíduos aprendem também na sua relação uns com os outros nos espaços públicos. Saviani é um dos autores que também vai questionar o modelo escolar que temos reproduzido. O autor questiona, sobretudo, se a escola é de fato capaz de formar indivíduos autônomos, que atuem dentro de um Estado democrático de modo ativo, crítico e transformador. Ele inclusive reavalia se esse tem sido de fato o objetivo da educação pública:

\begin{abstract}
$\mathrm{Na}$ verdade, podemos constatar que a maioria dos dirigentes educacionais, dos gestores escolares e dos professores quando enunciam esse objetivo estão querendo uma escola que forme pessoas que saibam ocupar seu lugar na sociedade, que sejam disciplinadas, ordeiras; que respeitem os outros; reconheçam a diversidade; acatem a hierarquia. Em suma: que sejam submissas e conformadas. Eis aí o paradoxo: o mesmo raciocínio coerente e plausível que respalda o papel da escola de formar para o exercício consciente da cidadania gera conclusões contraditórias. Assim, quando, diante da pergunta que escola queremos, respondemos que queremos uma escola que forme para o exercício consciente da cidadania, encontramo-nos diante de expectativas contraditórias: queremos, pela ação educativa, contar com cidadãos ativos, críticos e transformadores, mas no fundo desejamos que esses mesmos cidadãos sejam dóceis, colaboradores, compreensivos das diferenças e desigualdades, respeitosos da ordem social e conformados à situação vigente; submissos, portanto, às normas e valores próprios da sociedade tal como se encontra constituída. (SAVIANI, 2017, p.654)
\end{abstract}

Da mesma forma, verificamos também que, com a expansão da oferta de vagas nas redes públicas de ensino, a incapacidade desse modelo tradicional de

${ }^{26}$ Cf. Carta das Cidades Educadoras. Gênova. Disponível em: http://www.edcities.org/redeportuguesa/wp-content/uploads/sites/12/2018/09/Carta-das-cidades-educadoras.pdf Acesso em: 02 de março de 2020. 
escola de educar para a diversidade ficou ainda mais evidente. Isto ocorre uma vez que esse modelo não dialoga com as especificidades dos públicos que ele atende, tomando todos como um corpo homogêneo de indivíduos que recebe os conteúdos de forma pacífica:

(...) atribui-se ao sujeito um papel irrelevante na elaboração e aquisição do conhecimento. Ao indivíduo que está adquirindo. conhecimento compete memorizar definições, enunciados de leis, sínteses e resumos que lhe são oferecidos no processo de educação formal a partir de um esquema atomístico. (MIZUKAMI, 1986. p.11)

Contudo, se por um lado, diante desse atual quadro, alguns pensadores começam a relativizar a própria legitimidade da instituição escolar, por outro, há quem acredite que se deva enrijecer ainda mais sua estrutura. De um modo geral, pode-se falar nesse segundo grupo como o daqueles estudiosos e profissionais que acreditam que o modelo da escola tradicional, o qual, afinal, ainda persiste notadamente como o modelo hegemônico de educação, é o que deve mesmo prevalecer e ser prestigiado pelas políticas públicas. Vemos o quanto isso se manifesta na busca por modelos mais eficazes, submetidos a uma rigorosa e constante avaliação de resultados. Dentro dessa lógica, são valorizadas, então, as metas de escala nacional, rankings e um conjunto de medidas que geram um ambiente pouco propício para um trabalho crítico e reflexivo. Algumas dessas medidas acabam por gerar outras burocracias dentro da escola e alienam ainda mais o professor de seu trabalho com os alunos, que deveria ser o foco de suas preocupações. O sentido daquilo que ele faz passa a ser orientado de fora e apenas aquilo que é quantificável e analisável por determinados protocolos passa a ser valorizado, o que gera uma negligência com relação a importantes aspectos da formação humana.

Essa tendência se expressa muito claramente naquilo que Hermann denomina como uma "ansiedade tecnicizante" (HERMANN, 2002, p.87), a qual requisita muito mais a instrumentalização da relação pedagógica do que uma formação propriamente dita, ou seja, uma relação dialógica baseada no pensamento livre e crítico. Por conta dessa tendência, o debate acaba por girar em torno de preocupações com a eficácia e os resultados de determinados procedimentos. Essas exigências são geralmente acompanhadas de grandes frustrações, pois quando os objetivos não são alcançados, há uma profunda 
sensação de perda de sentido sobre o próprio fazer pedagógico. Como resultado, vemos a busca insaciável por novos modelos que, na esperança de romper com modelos mais antigos - geralmente questionados apenas quanto a sua eficiência -, provoca uma enxurrada de produções científicas que nos colocam diante de um angustiante malabarismo, em que a escola é forçada a se equilibrar entre uma perigosa naturalização de um modelo escolar e o combate a sua mistificação.

A fala do ex-ministro da Educação, Cristovam Buarque, em entrevista a Viviane Mosé (2015) reflete bem essa tendência:

Você tem que provar que é bom o tempo todo, o endereço geográfico é menos importante do que o eletrônico. Você vai poder aprender de casa, o professor terá que assumir que não sabe tudo, vai ter que ter um diálogo com o aluno e uma qualidade de outros itens que o mundo de hoje exige. Por quê? Porque a velocidade com que o conhecimento avança é muito grande. (...) A universidade não é capaz de acompanhar isso, há cursos que já deveriam estar fechados há muito tempo e a universidade continua insistindo em formar esses profissionais. (BUARQUE apud MOSÉ p.169)

Não só a ansiedade pelo novo, mas a noção de que a escola deve servir às urgências sempre atuais da sociedade e do mercado é algo que está presente na fala do ex-ministro e que já foi alvo de críticas de diversos pensadores da educação. Tal é o caso de Rui Canário (apud Mosé), que acredita que os saberes de várias gerações deveriam ser valorizados dentro de uma teia de relações sociais rica, na qual cada um pode aprender com o outro. Para ele, nossa sociedade tem se tornado uma "multidão solitária", desumanizada e violenta. Nessa perspectiva, um ensino que não está minimamente preocupado com as relações humanas tende a reforçar essa tendência de isolamento dos indivíduos.

Não podemos desconsiderar que de fato as transformações no mundo social e do trabalho não aceitam mais as respostas que a escola tem para oferecer e que, para compreender esse novo contexto, é de fundamental importância que se mude a relação com o conhecimento. Contudo, parece claro que o mundo contemporâneo exige uma educação que extrapole os limites do espaço físico da escola. Exige-se que aquele que aprende seja ouvido e que sua opinião seja levada em consideração. Nesse sentido, a escola não deve prender-se a grades curriculares, mas a temas, assuntos e questões mais urgentes. Uma dessas questões é, sem dúvida, o modo como temos dialogado com as diferenças e, como podemos, com as nossas diferenças, sermos ouvidos na busca por uma maior 
igualdade. É nesse sentido que alguns pensadores irão buscar, como alternativa à polarização, uma transformação da escola.

Embora tenhamos apresentado aqui dois polos radicais que disputam os rumos da escola e o sentido da educação, não é de se imaginar que, em regra, o debate se reduza a eles. Muito pelo contrário, uma ampla maioria de pensadores e pesquisadores da educação, bem como de educadores, visa uma transformação da escola sem que isso signifique abandonar o projeto de uma educação escolar questionadora e libertadora, mas que também qualifique intelectualmente os alunos. É por acreditar nessa possibilidade de transformação que o debate continua vivo e inúmeras reflexões se realizam no campo da educação. Essas reflexões têm por objetivo melhorar a prática dos professores, repensar os currículos, usar a avaliação em prol da aprendizagem, etc. Tudo isso tendo em vista aquele que aprende, levando em conta as suas singularidades, ou seja, aquilo que ele incorpora em sua inserção em um determinado contexto social, sabendo que é a partir desses conhecimentos que ele já carrega que ele irá aprender. Paulo Freire $^{27}$, inclusive, com a ideia de valorizar o conhecimento local e os saberes prévios dos alunos, contribuiu enormemente para a superação dos modelos tradicionais de escola. A ideia de transformação da escola deve muito a ele no Brasil.

É importante acentuar novamente que essa polarização em torno da legitimidade da educação escolar institucionalizada não esgota a questão. Existe uma terceira abordagem, na qual podemos incluir a maior parte dos pesquisadores e educadores que se propõem buscar uma educação transformadora por meio da escolarização. De acordo com esses autores, o caminho seria o de repensar todo um conjunto de medidas que incluem, por exemplo, metodologias de ensino e de avaliação, a elaboração do próprio currículo escolar, revendo quais saberes ele têm privilegiado. Em outras palavras, por intermédio do autoquestionamento e da confrontação com vertentes críticas do pensamento educacional, tornar a escola permeável às transformações necessárias. Considera-se que a escola ainda seja uma instituição legítima dentro de nossa tradição - que, aliás, começa a experimentar agora uma maior escolarização com muitas dificuldades.

Diante da questão que se coloca, podemos mencionar, por exemplo, a concepção de Canário (2006) de que de tempos em tempos a escola se vê diante

${ }^{27}$ Cf. FREIRE, Paulo. Pedagogia do Oprimido. Rio de Janeiro: Paz e Terra, 2014. 
de uma crise na qual sua legitimidade é questionada. Diante dessa crise e na tentativa de superá-la é que ela se autocompreende e se altera. Caso a escola não reconheça essa crise e não a supere, ela mesma corre o risco de ser considerada cada vez mais uma instituição superada, perdendo assim sua legitimidade dentro da sociedade. Numa leitura hermenêutica, aquilo que a escola ensina dentro de seus currículos é passível de ganhar e perder sua legitimidade dentro de uma tradição. Mesmo que, por acaso, ela tente conservar sua prática e o conhecimento que dissemina, ela nunca conseguiria fazê-lo por completo, uma vez que o sentido daquilo que ela ensina encontra-se em constante transformação dentro da tradição na qual ela se insere.

Evidentemente, podemos aí nos perguntar em que medida é possível por sob revisão o modo como atua a instituição escolar, fazendo com que ela deixe de ser algo que hoje ela é e passe a ser algo diverso. Quando pensamos sobre a escola, não podemos imaginar que ela se limite a um espaço físico de um prédio onde pessoas se encontram com objetivos meramente educativos, orientadas por um conjunto de legislações. Ela existe como espaço físico, mas também como algo que se dá numa tradição, como um conjunto de comportamentos. Esse é um ponto que coloca também em evidência o fato de que quando se fala de escola não se está falando apenas de uma instituição monolítica. Quando falamos sobre "a" escola, talvez falte uma referência absoluta para o termo. Em outras palavras, existem diversas escolas, que atendem também comunidades escolares diversas. Contudo, ainda nos casos em que se reconheça que a mudança seja urgente e necessária, certamente essa mudança não será impulsionada apenas pela força de uma justificação racional, por mais convincente que ela seja. Como observa Gadamer, a tradição é capaz de determinar a existência de instituições e comportamentos com tal força que, na maior parte do tempo, a eles aderimos de modo quase automático sem sequer nos darmos conta de sua essência histórica. Contudo, como nos alerta Gadamer:

É evidente que a expressão que utilizo, às vezes, dizendo que importa aderir à tradição, favorece a mal-entendidos. Não significa uma preferência pelo tradicional, ao qual deveríamos nos submeter cegamente. A expressão "adesão à tradição" significa, antes, que a tradição não se esgota no que sabemos de nossa própria tradição e de qual temos consciência, de tal modo que pudéssemos suspendê-la mediante uma consciência histórica adequada. A mudança do vigente é uma forma de adesão à tradição não menos que a defesa do vigente. A tradição se dá propriamente numa constante mudança. A "adesão" a ela impõe-se como 
formulação de uma experiência, em virtude da qual nossos planos e desejos sempre se adiantam à realidade, como se não tivessem ligação com essa. (GADAMER, 2004, p.312)

Assim, para além daquilo que nos colocamos como tarefa "em nossos planos e desejos", como fala Gadamer, existe o acontecer da tradição ao qual estamos vinculados necessariamente. Isto significa dizer que mesmo quando desejamos mudar ou preservar algo, sempre o fazemos dentro dos limites daquilo de que somos capazes de estabelecer algum afastamento. Isso não significa de modo algum uma limitação, mas antes o reconhecimento de que não nos deslocamos para fora dessa tradição como se nossos anseios por mudança "não tivessem ligação com essa”. Na verdade, já sempre nos adiantamos a essa "realidade", projetando uma nova "realidade", a partir de um conjunto de mudanças que desejamos ver acontecerem.

Isso significa dizer que não somos subjetividades solitárias que se colocam diante de uma mesma realidade que se impõe objetivamente para nós revelando seus problemas e contradições. Essa situação garante que possamos assumir posições e elaborar projetos conjuntos a partir de nossas angústias e anseios é o fato de contarmos que outras pessoas, possam compartilhar do significado daquilo que comunicamos.

\section{2. \\ Sobre o planejamento do futuro ${ }^{28}$ na educação}

No ano de 1965, Gadamer escreveu um ensaio sobre o progresso que as ciências da natureza haviam alcançado e a expansão de seu caráter tecnicista para todos os âmbitos da vida social. O autor constatou que esse era contexto em que, pela primeira vez, começava-se a pensar em uma ordem mundial. No entanto, não no sentido de reconhecer uma ordem já existente, mas de planejar e criar uma nova ordem. Assim, a despeito de haver ou não um consenso com relação a quais seriam os objetivos a serem alcançados e qual seria a ordem justa, o "especialista em economia e sociedade" ganhava uma fundamental importância como operador desse planejamento:

\footnotetext{
${ }^{28}$ GADAMER, Hans-Georg. Sobre o planejamento do futuro (1965) in Verdade e Método II complementos e índice. Tradução de Enio Paulo Giachini. 2. ed. Petrópolis: Vozes, 2002.
} 
Só agora o pensamento científico, à base de nossa civilização, apoderou-se de todos os ambitos da práxis social. A investigação científica do mercado, a condução científica da guerra, a ciência da política externa, o controle científico da natalidade, a ciência para a condução da vida humana etc. conferem ao especialista em economia e sociedade um lugar central. (GADAMER, 1997, p.183)

Isso, no entanto, não elimina o fato de que "o conceito de ordem mundial supõe necessariamente uma diferenciação de conteúdo" (idem), e que esse conteúdo se altera quando escolhemos qual ordem deve prevalecer. Um exemplo que o autor evoca é o da economia. Mesmo em se tratando do âmbito econômico, no qual se pode mais facilmente chegar a uma representação factual de ordem, não há consenso sobre qual ordem deva prevalecer. Isso porque não há como pensar em economia sem que se tenha claro o que se pretende alcançar em termos sociais mais amplos. As escolhas no campo da economia, portanto, dão-se no interior de uma determinada concepção de mundo e de um determinado projeto de mundo em consonância com essa concepção. Essas decisões implícitas, ou explícitas, determinam se, por exemplo, é preferível adotar uma economia de mercado, na qual as empresas possam lucrar livremente "em prol do crescimento generalizado do bem-estar ou se devemos preferir, por motivos político-sociais, uma economia estatal e, portanto, burocratizada, apesar de seu menor grau de eficiência” (GADAMER, 1997, p.184). Esse é um dilema que dividiu o mundo até poucas décadas atrás, e que ainda persiste. Assim, podemos ver que nem mesmo a economia deveria ser considerada em uma perspectiva puramente matemática, posto que ela não é da ordem de um conhecimento absolutamente racional. Gadamer deixa nítido que há na economia também um lado político que deve ser disputado na construção da chamada ordem econômica mundial. O primado desse horizonte político mais fundamental deixa nítido que o consenso é algo que efetivamente nunca se pode alcançar. E é por chamar a nossa atenção para o primado aberto da prática que a hermenêutica é tão interessante para pensarmos a educação.

Voltando para o campo da educação, precisamos, entretanto, admitir que quando pensamos em um planejamento para o futuro, podemos admitir que exista também um aspecto racionalizável da ação a respeito do que é possível ainda conservar algum sentido de consenso. O crescimento da oferta de ensino, a busca por melhores resultados nas avaliações e o nível de escolarização da população ao menos no que se refere aos anos de estudos - é algo com relação ao que se 
pode estabelecer alguma relação objetiva. Contudo, quando realizamos a leitura desses dados, vemos que o processo de democratização não trata simplesmente de colocar um número maior de pessoas nas escolas. Existe um nível político que é o da escolha, por exemplo, sobre qual projeto de educação desejamos empenhar nossos esforços. O campo da educação é, sobretudo, um campo de questionamentos sobre o próprio sentido da educação. Por esse motivo, a inclusão dos alunos na escola e até mesmo o aumento da escolaridade da população não podem ser tomados como um valor em si. As disputas políticas estão presentes desde as deliberações sobre a natureza da instituição que vai oferecer a educação se será a iniciativa pública ou privada - até a escolha dos saberes privilegiados pelo currículo escolar, passando pelas metodologias de ensino, o reconhecimento e a legitimação da autoridade do professor e o modo como a escola se abre para compreender e dialogar com as diferenças trazidas pela comunidade que recebe.

A falta de consenso sobre o que queremos para o futuro e sobre em que estamos empenhando nossos esforços gera inclusive múltiplas interpretações na leitura dos primeiros resultados obtidos com a democratização do ensino no Brasil. Se para alguns a escola pública está perdendo sua qualidade, haja vista os resultados das avaliações institucionais de escala nacional e internacional, para outros, o desempenho insuficiente dos alunos nas avaliações não pode ser tomado como um fator isolado para medir a qualidade das escolas. A educação escolar está passando por um importante processo de transformação e, apesar da falta de investimento adequado, hoje ela se encontra mais atenta em buscar as melhores condições para atender a um público que antes ela não atendia ${ }^{29}$.

Com isso, mais uma vez caímos numa questão insolúvel: a falta de um consenso mínimo sobre qual deva ser nosso projeto de educação escolar. A constatação de que vivemos uma crise na educação, como já falamos, torna ainda mais evidente essa falta de consenso. Quando se pensa em saídas para a crise, vertentes diversas apontam para caminhos que muitas vezes são muito conflitantes. A própria ideia de crise é disputável em última instância. Como é possível, então, sair desse cabo de forças? Tomando como referência o que nos diz Gadamer a respeito da possibilidade de encontrar um caminho para a ordem

${ }^{29}$ Cf. CANDAU, Vera Maria. Educação Intercultural e Práticas Pedagógicas. In: Relatório Parcial da Pesquisa Direitos Humanos, Educação, Interculturalidade: construindo práticas pedagógicas, set de 2013. 
mundial, vemos que ele coloca os seguintes questionamentos e aponta para a seguinte conclusão:

Será possível pensar a ideia de uma ordem política determinada que não suscite ideias contrárias? Será possível pensar ideias políticas de ordem que não favoreçam a uma ou a outra das potências políticas existentes, de tal modo que o seu favorecimento implique o desfavorecimento da outra? Será que a existência desses antagônicos interesses de poder constitui uma desordem? Não serão eles a própria essência da ordem política? (...) Todas essas representações específicas sobre uma ordem formam, porém, o tecido da política mundial. Determinadas por tantos pontos de vista diversos, parece impossível que determinada ideia política de ordem consiga alcançar unanimidade geral. (GADAMER, 1997, p.185 e 186)

A impossibilidade de se alcançar um consenso não pode ser compreendida como a impossibilidade de caminhar em alguma direção. Muito pelo contrário, a multiplicidade de posições, que só se revela no diálogo, desnaturaliza algumas posturas essencialistas acerca do que deva ser a educação. Somente quando se coloca algo em questão é que a identidade de cada uma dessas posições se revela para si mesma e para o outro. Uma das características fundamentais dos regimes democráticos, inclusive, é a possibilidade de haver essa multiplicidade de posições. Assim, as divergências sobre qual projeto para a coletividade deva prevalecer não é o que impossibilita o diálogo, mas sim aquilo que o requisita.

Gadamer vai mais além e questiona se é mesmo possível e desejável a busca por uma ordem, por um planejamento racional, no que tange à organização das "formas de vida dos povos, cunhadas pela religião, usos e costumes da tradição" (ibid., p.186). Ele compreende que essa questão, contudo, por si só, configura-se inclusive como uma afronta à ciência, tamanha a fé, muitas vezes injustificada, que nosso tempo deposita nela. Para o autor, a questão se torna mais evidente quando observamos que a resistência das tradições morais e religiosas perde cada vez mais espaço diante do poder das narrativas cientificistas. Qualquer pensamento fora dessa lógica fica cada vez desvalorizado:

Parece que hoje esse tipo de resistência está desaparecendo e abrindo caminho para as possibilidades técnicas de nossas descobertas científicas. O especialista oferece as possibilidades implícitas em sua ciência. Quando se deve decidir sobre a facticidade dessas possibilidades, a consciência pública apela novamente para a ciência. (GADAMER, 1997, p.187)

Por mais que estejamos experimentando hoje uma atitude negacionista com relação àquilo que acreditávamos ser verdades inabaláveis alcançadas pelo método científico, vemos que mesmo esse discurso negacionista se vale das 
mesmas estratégias narrativas, formulações e palavras chave utilizadas pelos cientistas, funcionando como uma espécie de ciência alternativa, que os cientificistas denunciam como pseudociência. Dito de outra forma, o vocabulário e o gesto continuam a serem os mesmos no campo da disputa discursiva. Isto revela mais uma vez, não uma desconfiança crítica, mas uma apropriação narrativa perigosa e problemática. Diante de tal fenômeno, podemos ainda nos questionar se ele não é fruto de uma frustração gerada justamente lá onde o método não alcançou os resultados. Lá onde a vida prática se mostrou complexa e imprevisível demais para ser equacionada, ou seja, quando mesmo tendo se planejado, controlado os fatores de risco, implementado as medidas cabíveis não se alcançou os resultados projetados.

Gadamer não está evidentemente negando o poder explicativo das ciências, nem mesmo tentando prescrever o que ela pode ou não fazer. $\mathrm{O}$ que o autor tenta nos alertar aqui é que existe uma dimensão da vida que escapa a toda e qualquer objetificação. O que faz com que algumas culturas se desenvolvam de determinado modo, com que algumas pessoas busquem respostas na fé religiosa ou até mesmo modos de vida alternativos é algo que não pode ser explicado totalmente. Nem mesmo se espera que as respostas encontradas tenham fundamentos racionalizáveis.

É justamente aí que a educação encontra seu lugar de atuação, uma vez que ela pode ser um lugar privilegiado para o diálogo. Contudo, a escolha política do modo como ela irá atuar dentro da sociedade deve ter claro para si em que medida ela está aberta a dialogar com as diferenças. Até mesmo a escolha das metodologias de ensino requisita uma ampliação dos horizontes compreensivos e uma sensibilidade daquele que se dispõe a educar e a reconhecer a natureza de seu trabalho, o que é diferente de buscar "o bom funcionamento como um valor em si” (GADAMER, 1997, p.189).

\footnotetext{
A base do ideal de administração é uma ideia de ordem que não comporta nenhum conteúdo específico. O objetivo declarado de toda administração não é o saber sobre que tipo de ordem deve dominar, mas saber que tudo deve ter uma ordem. (ibid., p.188)
}

Portando, um planejamento de futuro sem um conteúdo definido, baseado apenas em medidas administrativas pontuais tende a mascarar e reproduzir a exclusão e a cegueira às diferenças. Uma vez que a ideia de que se deve 
estabelecer a ordem pela ordem e que, portanto, as "coisas devem estar no seu devido lugar" acaba por passar ao largo das desigualdades que foram produzidas ao longo da história. O reconhecimento da existência de perspectivas concorrentes e da tensão entre elas, em todo e qualquer planejamento, é o que requisita o diálogo nas disputas do campo político.

Até mesmo dentro de uma sala de aula, a ideia de ordem não pode ser tomada como um valor em si. Um "bom funcionamento" de uma sala de aula não deve se reduzir ao mero cumprimento de protocolos. Quanto mais uma aula envolve os seus participantes, menor será a possibilidade de que ela seja replicada da mesma forma em dois grupos diferentes. Isso porque, mesmo quando se pretende abordar a mesma questão, para além do que possa ter sido planejado pelo professor, cada grupo trará para o diálogo pedagógico suas próprias concepções prévias e o debate a partir delas fará com que cada aula ganhe um formato único.

Acerca disso, Gadamer, mais uma vez, recorre aos gregos para caracterizar duas dimensões do saber. Para ele, aquilo que nos diálogos platônicos foi caracterizado como um "saber objetivo", também pretendia alcançar uma universalidade, algo que se aproxima hoje de uma ordem que poderia ser obtida por meio de uma administração perfeita. Segundo Gadamer, "os gregos chamavam-na de tékhne, o saber a respeito do que é passível de ser produzido e feito, capaz de alcançar sua própria perfeição" (1997, p.189). A tékhne é, contudo, um saber sobre o uso apropriado dos recursos corretos e da sucessão metódica das fases de produção de algo. Ainda de acordo com a interpretação gadameriana de Platão, a tékhne é um saber específico e, por isso, "não existe em vista de si mesma", ou seja, ela se coloca ao lado de outras estruturas de meios e fins e requisita "a superior de um saber que conhece o emprego correto de todo saber específico" (idem). Essa tékhne superior seria a política. Desse modo, o político seria o "especialista dos especialistas". Aquele que encontraria o lugar apropriado para o uso de cada tékhne. Evidentemente, Gadamer estava atento à diferença existente entre a polis grega e o mundo atual. Contudo, ainda assim, resguardada as proporções, ele afirma que "o mundo administrado de maneira perfeita corresponderia exatamente ao ideal da polis" (1997, p.190). Esse ideal, contudo guarda dentro de si contradições que não se resolvem facilmente: 
O fato de que, na totalidade de sua existência, o homem possa tornar-se um objeto a ponto de ser considerado produto em todas as relações de sua vida social, que possa ainda existir um especialista que "ele" mesmo não é, para administrar cada "homem" junto com todos os outros e que esse especialista seja ele mesmo administrado por sua própria administração, tudo isso provoca evidentes confusões. (GADAMER, 1997, p. 190)

Somente a distinção aristotélica entre tékhne e phronesis $^{30}$, de acordo com Gadamer, seria capaz de clarificar essa confusão. Isso porque Aristóteles reconheceu o primado da dimensão da vida prática, que é iluminada e orientada pelos pontos de vista moral e político, as quais constituem o ser ético do homem. A phronesis, que desempenha um papel importante na "filosofia prática" aristotélica, não seria apenas um exercício da racionalidade prática, mas também uma virtude. Ela permite uma relação interpretativa com as coisas, de modo mais próximo uma vez que, para ser bem sucedida, ela precisa estar de acordo com o ethos. O ethos comporta os traços históricos e culturais de cada grupo. Desse modo, Gadamer conclui que a expressão "filosofia prática" serve para indicar que "para os problemas práticos não convém fazer-se um uso de determinado tipo cosmológico, ontológico e metafísico" (GADAMER, 2004, p.353). A phronesis, então, não pode também ser confundida com a episteme, que é o conhecimento das ciências. Ela deve ser compreendida como uma virtude nela mesma, e não como um instrumento para atingir a virtude na medida em que ela se revela no agir daqueles que conseguem encontrar a medida certa das coisas a cada circunstância e, com isso, agir com prudência.

\begin{abstract}
Mesmo na suposição utópica de uma física da sociedade, não nos livraríamos da confusão indicada por Platão quando estilizou o homem do Estado, isto é, o agente político, como um especialista mais gabaritado. Este saber do físico da sociedade, se posso chamá-lo assim, bem pode possibilitar a existência de um técnico da sociedade capaz de produzir tudo o que imagina, mas permaneceria alguém que não sabe o que se deve realmente fazer com o que ele mesmo sabe. Aristóteles refletiu profundamente sobre essa confusão. Chamou, por isso, o saber prático, que trata de situações práticas concretas, de "outro tipo de saber". (GADAMER, 1997, p.191)
\end{abstract}

A crítica de Gadamer, então, incide sobre um desenvolvimento teóricopolítico, orientado por bases técnicas que não leva em conta a dimensão histórica e social, e que por isso, acaba por promover inúmeras distorções. Gadamer,

${ }^{30} C f$. FERREIRA, Adriana M. R. Gil. Hermenêutica e educação: aproximações. Dissertação (Mestrado) -Pontifícia Universidade Católica do Rio de Janeiro, Departamento de Educação, 2011. p 89-96 
contudo, afirma que "o que defende não é um irracionalismo opaco, mas a clareza da razão que sabe encontrar o factível a cada vez, num sentido prático-político" (idem), que tem uma lida interpretativa aberta com as diferentes situações, observando suas especificidades e encontrando nelas mesmas as medidas para as ações.

É exatamente nesse ponto que o pensamento de Gadamer sobre a compreensão, tradição e horizontes históricos se aproxima do pensamento de Aristóteles. A investigação sobre a phronesis e sua dimensão interpretativa revela a implicação política e ética de toda a compreensão, o que realça também a dimensão prática de sua filosofia hermenêutica. A hermenêutica de Gadamer preconiza um indivíduo que compreende na medida em que está vinculado a um específico horizonte histórico e que age no mundo de forma interpretativa. Dessa forma, o que orienta a sua ação ética é esse mesmo saber prático e não uma estrutura universal de sua razão. O que orienta, em última instância, as ações individuais no campo prático da vida - sem que na maioria das vezes se reflita sobre essas orientações - são as convicções políticas e morais que incorporamos em nossa tradição.

O que é factível não é simplesmente o possível ou, dentro do que é possível, simplesmente o mais vantajoso. Mas toda possível vantagem ou preferência de um sobre o outro mede-se por um determinado critério, que alguém se impõe ou que lhe é imposto. Trata-se do cerne do que na sociedade é válido, das normas que, cristalizadas em convicções políticas e morais, orientam toda educação e autoformação, e mesmo a educação para a objetividade científica. (GADAMER, 1997, p.193)

Desse modo, quando desnaturalizamos esses critérios, reconhecemos a sua historicidade e os vemos ao lado de outros critérios que também foram construídos em tempos e contextos diferentes, regidos por interesses e convicções diferentes, temos, portanto, uma perspectiva mais ampla sobre como agimos. Isso, contudo, não irá invalidar tais ações, nem significará que não estamos mais condicionados por nosso horizonte histórico de formação. Muito pelo contrário, essa ampliação abre caminho para que nos responsabilizemos por nossas posições e possamos exercitar, ao menos, algum autoquestionamento. Na educação, isso se reflete nos posicionamentos que adotamos e no reconhecimento de que não basta um "saber técnico para estarmos a caminho de um futuro esplêndido" 
(GADAMER, 1997, p.192), que a cada vez, nossas ações são condicionadas por aquilo que de antemão já nos parece justo de acordo com o ethos da tradição.

Quanto mais decisivamente intervir o teor dos preconceitos sociais ou políticos dominantes, tanto mais ficcional parecerá o puro especialista e com ele o conceito de uma racionalidade cientificamente segura. Em todo âmbito das ciências sociais modernas deve-se admitir que elas não conseguem dominar o nexo entre meios e fins, sem dar preferência a determinados fins. Se explorássemos a fundo os condicionamentos internos dessas implicações, acabaria se mostrando a contradição entre a verdade atemporal, postulada pela ciência, e a estruturação temporal daqueles que usam a ciência. (GADAMER, 1997, p.192)

Com isso Gadamer não está afirmando que não existe um ideal moral ou político para além do que já vigora na ordem social em que nos encontramos. Ou seja, não agimos de forma a apenas corroborar o modelo já existente. Muito pelo contrário, cada "decisão concreta do indivíduo, antes, é codeterminante para a validade universal" (1997, p.193). Isto significa que na nossa ação afirmamos, ou colocamos à prova e ressignificamos, o compreendido em nossa tradição. O exemplo que Gadamer nos traz é o da linguagem, que "sobrevive não em virtude do rígido emprego das regras, mas pela constante reformulação no uso da linguagem, em última instância, pela ação de cada indivíduo" (idem).

Assim, a educação e os projetos que fazemos se modificam a cada vez que agimos de modo interpretativo, buscando a adequação da mesma a situações concretas. Como já vimos, é a nossa ação que conserva algo como as instituições escolares em nossa tradição e, ao mesmo tempo, o que as modifica, tornando-as mais ou menos adequadas às exigências de nosso horizonte histórico. Somente assim, conseguimos também "ultrapassar o conhecimento genérico e descobrir o que é realmente factível e possível" (idem) para a escola, abrindo-nos ao diálogo com outras perspectivas de conhecimento.

A possibilidade de haver posições concorrentes sobre a mesma questão e o debate entre elas requer, contudo, um estado de equilíbrio no qual nenhuma posição anule a outra pela força simplesmente. Gadamer considerou que no "equilíbrio podemos observar a verdadeira condição da liberdade humana" (GADAMER, 1997, p.195) e que nele se conquista a liberdade de ação dos indivíduos. Por essa razão, aquele que governa, deve antes de qualquer coisa buscar o equilíbrio: 
Governar não é fazer. Governar é, antes, um adaptar-se a circunstâncias. Dois momentos, intimamente ligados, perfazem a essência do governar: a manutenção de um equilíbrio, que oscila dentro de um espaço de jogo bem delimitado, e a condução, isto é, a determinação de um direcionamento do movimento que possibilite manter esse equilíbrio oscilante. (idem)

Evidentemente, num estado de total desequilíbrio de forças, a recuperação desse estado de equilíbrio requer, sim, determinadas ações. Nesse sentido, "a intervenção incide de fora de um sistema que equilibra e regula a si próprio" (1997, p.198). Assim, a intervenção deve ter como fim proporcionar a todos a liberdade de ação e a capacidade de individualmente planejar e realizar suas escolhas dentro de suas próprias vidas. Com isso, Gadamer nos diz que:

Evidencia-se então que todo nosso planejar e fazer realiza-se dentro desse estado de equilíbrio instável, presente em todas as nossas condições de vida. Essa ideia de equilíbrio não é apenas uma das mais antigas concepções de ordem política, a partir de onde se delimita e define o grau de liberdade do sujeito ativo. Equilíbrio é uma determinação fundamental da própria vida. Nele enraízam-se todas as possibilidades indeterminadas e ainda definidas do vivo. O homem da civilização técnica e científica está tão sujeito a ele quanto o mero vivente. (...) O fator da vontade e do agir humanos só tem importância decisiva onde as forças mantêm o equilíbrio. (...) A conquista da liberdade de ação pressupõe a criação de um estado de equilíbrio. (GADAMER, 1997, 195)

Tanto na busca pelo equilíbrio, quanto na manutenção do mesmo, o confronto com situações sempre novas exigiria uma "deliberação-consigo-próprio, feita pelo indivíduo (ou também pelo grupo) diante da situação que exige uma decisão" (GADAMER, 1997, p.198). Essa é uma ideia que Gadamer também adota de Aristóteles e que é bastante diferente da busca por um critério universalmente válido nos moldes modernos, onde o indivíduo consulta uma razão interior. Isso porque essa deliberação exige que se dê a palavra ao outro na busca pelo factível ponderando-se cada possibilidade que se apresenta.

Vemos assim, a partir de Gadamer, que todo planejamento não teve tomar o ideal de ordem e bom funcionamento como valores em si. O autor crítica a crescente racionalização da vida e critica a postura de se buscar a ordem acima de tudo sem considerar a natureza daquilo a que se tenta impor tal ordem. Isso porque, existe uma dimensão da vida prática, que é atravessada por valores e crenças, que redimensionam tudo aquilo que o modelo técnico-científico busca medir com precisão. Assim, Gadamer compreende que diante da multiplicidade de perspectivas, a busca por um equilíbrio entre forças mostra-se um movimento mais fecundo. Pois, é nesse equilíbrio que é possível deliberar com o outro 
levando em conta "as diferenças insuperáveis" que "nos ligam como seres humanos" (GADAMER, 1997, p.201).

Desse modo, numa perspectiva hermenêutica, todo planejamento acerca da educação deve dialogar com as diferenças inerentes a nossa tradição, isto é, com os horizontes históricos de formação de cada uma dessas diferenças, não no sentido de equalizá-las diminuindo a tensão entre elas, mas reconhecendo afirmativamente a existência das mesmas. Somente assim, é possível compor com o diferente na busca pela superação das desigualdades e na busca do equilíbrio do qual fala Gadamer.

\subsection{1.}

\section{A ideia de tolerância em Gadamer}

Há aqui uma referência significativa que consagra a relação já mencionada de fortaleza, segurança, generosidade com a tolerância e, inversamente, a proximidade da intolerância com a fraqueza: a tolerância não é irresolução que admite o direito de outrem, porque já não confia no seu próprio direito ou poder. O homem de Estado pode proclamar a tolerância universal em matérias religiosas, por indiferença e ceticismo em face da religião, como talvez terá feito o céptico iluminista no trono da Prússia. Não o fez por fraqueza, mas pela força da sua consciência política e da confiança no poder da consciência política dos seus súbditos, que sustém o Estado. (GADAMER, 2001, p.93)

A ideia de tolerância apresentada aqui por Gadamer parece, de um modo geral, não encontrar mais ressonância em nosso tempo. Aquilo que já foi sinônimo de fortaleza, segurança e generosidade, tem ganhado hoje um caráter completamente diverso. A tolerância parece já não ter mais o papel privilegiado que tinha outrora. Ao menos no mundo ocidental, a ideia de igualdade de direitos parece já bastante disseminada para que aceitemos conviver com o fato de que alguém possa escolher ou não tolerar o outro. Nesse sentido, tolerar ressoa como um ato de quem subjuga. De alguém que, por se encontrar em posição superior de poder, pode decidir o que e quem irá tolerar ou não.

É preciso, já de partida, observar que nos Estados modernos, já não temos mais o poder concentrado nas mãos de déspotas, que do alto de seu direito (natural ou divino) permitem generosamente que seu povo decida sobre os assuntos referentes, por exemplo, à própria fé religiosa. Valores como a igualdade e a liberdade são pressupostos indiscutíveis que herdamos da Modernidade, que constituem o modo como nos entendemos hoje como sociedade. Diante da busca 
incessante pela afirmação da igualdade de direitos entre raças, gêneros e etnias, algo como tolerar o outro já não parece, a princípio, ser suficiente.

É possível, no entanto, apenas com a ideia de liberdade e de direitos iguais alcançarmos o fim dos preconceitos que sustentam as discriminações? Recorrer a essa ideia já tão difusa de que "somos todos iguais" tem sido o suficiente para conseguirmos inibir o ódio e a intolerância às diferenças? Se por um lado, constatamos que tolerar parece pouco diante dos direitos individuais conquistados nos Estados democráticos, por outro, vemos que alguns grupos em vantagem de poder ainda se sentem no direito de tolerar ou não. Como se não bastasse, atuam como déspotas pouco esclarecidos demonstrando sua intolerância de forma violenta. Assim, vista desse modo, a tolerância já não parece algo tão irrelevante. Se ao menos houvesse tolerância nossa sociedade não se encontraria em melhores condições de convivência? Não estaríamos mais próximos de poder exercer liberdades individuais? Não estaríamos livres das violências diárias sofridas por aqueles que experimentam a intolerância? Essas são questões para a qual importantes pesquisadores voltaram a sua atenção. Nesse sentido, na busca por compreender mais a fundo a ideia da tolerância e o significado das diferenças, Souza nos diz que:

\begin{abstract}
Sem dúvida, a igualdade é um valor fundamental de nossa sociedade e da qual não estamos dispostos a abrir mão. No entanto, tem crescido entre nós a consciência de que o discurso sobre a igualdade nem sempre expressa plenamente a nossa condição humana, que é marcada fundamentalmente pela diversidade. Estamos descobrindo com mais força que não somos apenas iguais, mas também diferentes. E afirmar a igualdade não significa, em hipótese nenhuma, negar as diferenças que nos caracterizam. Hoje, mais do que nunca, vivemos num espaço e tempo marcados pela efervescência das questões trazidas pela diferença. Diferença de gênero, de raça, de classe social, de orientação sexual, de identidades, de origens, de pertencimentos, de geração, de capacidade física e mental etc. Diferença que enquanto direito ficou, até bem pouco tempo, ocultada pela força do discurso sobre $\mathrm{o}$ direito à igualdade. $\mathrm{O}$ nosso mundo é compreendido, cada vez mais, como multicultural, plural e diversificado. Neste sentido, a temática da diferença tem suscitado novas questões para o campo ético e elas não podem ser ignoradas ou minimizadas. É evidente que o direito à diferença não pode ser visto como algo que se opõe ao direito à igualdade, mas também não se pode negar que afirmar o direito à diferença traz novos desafios para esta temática. (SOUZA, 2005, p.279)
\end{abstract}

Gadamer afirma que a busca pelo equilíbrio é a tarefa principal daquele que governa. Compreendemos, então, que governar seja levar adiante projetos coletivos que garantam a liberdade de cada um de fazer escolhas individuais no que diz respeito ao âmbito privado de sua vida. Assim, num estado democrático, 
que preconiza a igualdade, quando existe um desequilíbrio, faz-se necessário a intervenção. Nesse caso, podemos interpretar que é a constatação de que existe um desequilíbrio de forças - que faz com que algumas diferenças resultem em desigualdades - o que nos leva a reivindicar tais intervenções. No campo social, essas intervenções pela busca de equilíbrio se traduzem nas políticas públicas. A oferta de educação pública, laica e gratuita para toda a população poderia então ser tomada como a principal e mais abrangente dessas ações no contexto brasileiro (AZEVEDO, 2008).

A intervenção de políticas específicas que atuem em demandas que emergem da sociedade, de modo a oferecer base para a superação de desigualdades, parece a princípio um caminho justo e eficaz. Contudo, essa forma de intervenção não encontra consenso mesmo entre os que defendem a igualdade de direitos. Mais uma vez, esse debate nos coloca na já citada disputa sobre quais devem ser os limites de atuação do Estado e o quanto ele deve interferir ou não nas questões sociais. Uma vez que, em última análise, a ampliação e a diminuição da atuação do Estado implica diretamente no investimento de recursos que são obtidos através de impostos e investimentos, que são um bem de toda a sociedade.

Compreendemos, contudo que essa é uma questão que não requisita apenas uma escolha técnica sobre qual modelo seria o mais eficiente. Para compreender a posição defendida pelos diferentes grupos, é preciso ver a questão no nível das disputas políticas, como já observamos anteriormente. Voltando, portanto, às questões que se colocam no campo das tensões sociais e ainda nos orientando pelo que nos fala Gadamer, colocamos aqui mais algumas perguntas: De quais horizontes históricos se originam tais disputas? O que faz com que determinados grupos detenham mais poder que outros? Por que, mesmo num estado democrático de direitos, ainda existe grupos sociais que brigam para manter seus privilégios?

Com a emancipação ideológica da burguesia - precedida por sua emancipação política, que teve na Revolução Francesa seu grande marco - o ideal da igualdade jurídica garantida pelos direitos civis, foi colocado como um pilar central. A autoconsciência da burguesia começa a ter na indústria seu fundamento mais sólido, nas suas atividades comerciais, nas suas criações, fábricas e escritórios - como observa Gadamer (2001, p.83). Ao mesmo tempo, as modernas ciências da natureza, encontram o caminho livre para se desenvolverem 
plenamente, sem mais nenhum entrave das questões religiosas - pelo menos no plano político. Uma nova consciência científica se instaura e as pesquisas metódicas se permitem lidar com os dogmas religiosos através de explicações histórico-culturais ou psicológicas.

$\mathrm{Na}$ visão de Gadamer, nossa sociedade experimenta, portanto, um novo modelo que se manifesta como uma herança do Iluminismo: "o domínio científico da natureza e (...) uma organização racional-construtiva do mundo social" (GADAMER, 2001, p.85). Nesse modelo, “o ateísmo representa a religião estatal, de um modo análogo ao papel que, há séculos, o Cristianismo desempenhou como religião estatal da Europa" (idem). Desse modo, "o ateísmo científico e a sua organização política apresentam uma posição, perante a qual todas as diferenças das religiões - consideradas politicamente - perdem a sua seriedade.” (idem). Mais do que isso, as religiões passam a representar uma afronta à ordem racional, algo exótico e concebível apenas enquanto excentricidade individual, porém sem fundamento e incompreensível em última instância, segundo o paradigma técnicocientífico $^{31}$. Assim, Gadamer avalia que:

De acordo com este estado de coisas, também o conceito de tolerância se perfila de modo diferente. Parece-me significativo o facto de o problema da tolerância religiosa já não nos surgir como o primeiro, mas sim como o último: e que, na correta apreciação das condições estruturais em que nos movemos, se deve dedicar uma atenção particular ao papel da economia. Pergunto-me qual poderá ser o significado da tolerância nestas circunstâncias modificadas. Já não se está tão seguro do que se deva e possa ser tolerante - ou temos de dizer que tudo o que não vive da dominação dos duros dólares existe apenas graças à tolerância? Por exemplo, a cultura? (GADAMER, 2001, p.87)

De modo bastante próximo ao que Gadamer avalia, contudo sendo um pouco mais específico, Paul Ricoeur também chama a atenção para o fato de ter surgido uma nova classe social na era moderna - a classe média. Essa nova classe ainda busca assegurar-se de sua posição e defender suas aquisições. Para Ricoeur, é como se "aqueles que ultrapassaram a fronteira de abundância sentissem toda vantagem social como uma aquisição ameaçada pelo menor sinal de retrocesso,

\footnotetext{
${ }^{31}$ Temos conhecimento de que tamanha secularização, descrita por Gadamer, mesmo no contexto europeu, é algo historicamente contestável. Muito embora o desenvolvimento técnico tenha trazido uma enorme transformação na ordem social, existe o entendimento de que ele não eliminou e nem mesmo reduziu de modo significativo a influência da fé religiosa no modo como as sociedades se organizam.
} 
devendo ser defendida contra a camada social imediatamente inferior." (RICOEUR, 1977, p. 151).

$\mathrm{Na}$ esfera social, a ausência de projetos coletivos se conjuga com o apagamento daquilo que a tradição poderia transmitir às gerações futuras. Estas experimentam, então, a “experiência 'selvagem' a partir do zero” (ibid, p. 150). Isto é algo que Gadamer também observa, ao afirmar que as "tradições vinculativas" se dissolvem diante das novas gerações numa "arbitrariedade inexperiente" (GADAMER, 2001, p.87). Assim, Gadamer questiona:

Onde está hoje a autoridade da geração influente e mais velha que podia comportar-se perante os mais jovens de modo tolerante ou intolerante e como se deve perfilar o impulso emancipatório das gerações posteriores, se tudo lhes é acessível e permitido? O que impele os jovens à intolerância não é a segurança dos seus novos conceitos de valor, mas pelo contrário, a sua secreta falta de orientação. (idem).

Essa era uma questão que preocupava Gadamer e que aparece também em uma conferência intitulada Educação é Educar-se, realizada dois anos antes de seu falecimento. Em um dado momento, Gadamer toma como exemplo um colega de trabalho estadunidense, a fim de questionar como tem acontecido a educação das novas gerações no âmbito familiar de nossa sociedade, sobretudo em seus primeiros anos de vida:

Se vocês pudessem imaginar os problemas que este pai terá por ter tornado estes primeiros anos mais fáceis graças ao excesso de televisão. Naturalmente aí se está cometendo um erro fatal. Nenhuma avaliação sobre o perigo que os meios de comunicação, em um caso como este, representa para o ser humano pode ser radical o suficiente. Pois se trata acima de tudo de aprender a atrever-se a formar e expor juízos próprios. O que não é absolutamente fácil. (...) O professor exerce uma função muito modesta se pretende influir neste processo. Nos aspectos em que em casa se fracassou por completo, normalmente o professor tampouco terá muito êxito. (GADAMER, 2000, p.20-21

Walter Benjamin, em seu importante ensaio, O Narrador, também chamou a atenção para o crescente processo de extinção do diálogo pela desvalorização das experiências vividas e que poderiam ser passadas não só de uma pessoa para outra, mas de geração para geração. Para Benjamin, "é como se estivéssemos privados de uma faculdade que nos parecia segura e inalienável: a faculdade de intercambiar experiências" (BENJAMIN, 1994, p.198). O autor compreende que existe uma relação íntima entre essa crescente extinção e as transformações nos 
modos de produção. A sabedoria, que se traduz como "o lado épico da verdade" não resiste às exigências de explicações verificáveis. Também a arte de narrar não comporta explicações causais, isso porque na narrativa, toda explicação é "substituída pela exegese, que não se preocupa com o encadeamento exato de fatos determinados, mas com a maneira de sua inserção no fluxo insondável das coisas" (BENJAMIN, 1994, p.209).

O preconceito contra os preconceitos da tradição parece ter, ao fim e ao cabo, conseguido atingir sua efetiva realização. Contudo, justamente lá onde o método científico não consegue fixar seu objeto com tanta precisão, o questionamento acerca dos fundamentos não deveria se opor à experiência. No contexto em que, sobretudo nas famílias com maior poder econômico, o especialista em neuropsicologia infantil, o pediatra, o nutricionista acabam ganhando um espaço cada vez maior na formação das novas gerações, essa questão se torna muito mais evidente. Quando se confia a educação a essas especialidades, encobre-se o sentido mais genuíno de experiência na qual ela se realiza: a de um recorte amplo da história, no qual a recorrência de dados e a abrangência de conceitos garantem alguma previsibilidade nos resultados. Uma nova tradição então começa a se instaurar, na qual nada se conserva e nada se fixa, como nos fala Benjamin (2008, p.118) em seu ensaio Experiência e Pobreza.

Gadamer compreende que em nosso tempo experimentamos nada menos que um novo modo de totalitarismo: o da racionalização científica do mundo social. Nesse contexto, a tolerância ganha então um novo caráter, ela deixa de ser uma virtude e passa a ser compreendida essencialmente como prova de fraqueza.

Há algo de intransigente no ideal da racionalidade científica, ao qual ninguém que seja prudente se pode opor. A sua imposição na realidade social é, de modo característico, designada como "racionalização". Como se alterou a ênfase desta palavra, cuja proveniência de ratio, de razão, está bem à vista! "Racionalização" significa a transformação do ambiente dominável em organização abrangente e total, alicerçada no planejamento, na metódica e na exploração racionais. Tudo o que nela pode fazer falta surge como uma imperdoável negligência. (GADAMER, 2001, p.88)

Gadamer, ainda evoca a experiência com os sistemas totalitários de sua época e lembra que "o totalitarismo não é favorável à tolerância" (GADAMER, 2001, p.89). Da mesma maneira, aquilo que é extraído de uma rigorosa análise científica também não o pode ser, mesmo quando o seu objeto é fruto de camadas 
e camadas de uma multiplicidade de valores construídos e sedimentados historicamente. Mesmo lá onde a própria ciência reconhece encontrar seus limites, requisitamos respostas e as aguardamos esperançosos.

Já não há, pois, um déspota que possa ser destronado. É o anonimato do poder que a todos nos engloba. Apraz-me então chamar a atenção para o seguinte: a ideia de tolerância adquire um novo significado, justamente porque já não pode ser exigida de quem ou dos poucos que detêm o poder. No fundo, já ninguém tem o poder, todos estão a seu serviço. (GADAMER, 2001, p.92)

A ideia aqui é a de que já não há uma figura central do poder de quem se possa, por exemplo, exigir tolerância. Não estamos mais a serviço de alguém que detém o poder, de alguém que representa o poder. É esse o horizonte histórico em que se vinculam nossos preconceitos. Recorrendo às justificativas que vão desde os valores de uma já opaca moral cristã ou, então, aos recortes arbitrários de infindáveis pesquisas científicas feitas acerca do comportamento humano, pessoas se sentem habilitadas para emitirem aquilo que ainda consideram ser suas próprias opiniões. Desse modo, mesmo diante da exigência já incontestável da liberdade de pensamento, contraditoriamente, o que temos é "o conformismo geral, que não conhece uma decisão refletida própria, mas tem em vista o êxito da adaptação perante os poderes e a sua - real ou suposta - opinião" (GADAMER, 2001, p.89). Assim, o que confere o poder político à lógica de racionalização da modernidade é o reconhecimento de que ela está presente por todos os lados e que deve ser o parâmetro para a organização de toda a vida. Com isso, "a convivência tolerante não significa justamente Direito" (idem). O que significa que não se pode contar com ela. Como nos fala Gadamer, "é da essência característica da tolerância que o espaço da convivência pacífica nunca seja objeto de uma delimitação precisa", pois somente "quando estão em jogo solidariedades mais profundas - por exemplo, no Estado iluminista, o interesse político na exclusão das contendas confessionais - é que a tolerância é possível enquanto virtude" (2001, p.89). Com isso, acentuando mais uma vez sua vocação aristotélica, Gadamer parece defender que é no campo da política que se deve fundar tal convivência, uma vez que somente nele é possível assegurar uma solidariedade real:

Ora importa dizer que a tarefa política foi, desde sempre, fundar o domínio sobre o homem numa solidariedade real e num consenso efetivo. Formas de vida patriarcais podem aproximar-se por si próprias deste ideal. Em todo caso, para as formas de domínio dos Estados, todo o postulado de harmonia entre homem e 
Estado é irrealista, porquanto toda a forma de poder, não apenas a do soberano absoluto ou da tirania, se pauta pela intensificação do seu próprio poder. Daí que toda a doutrina da política e das constituições estatais tenha por meta a limitação da ânsia de poder dos que o detêm e o consenso dos dominados. (GADAMER, 2001, p.90)

Assim, todas as democracias modernas precisam preservar suas constituições, agindo na estrita observância das mesmas, no modo de um acordo fundado na vontade geral que delega o exercício do poder político aos seus representantes. Esse modelo de democracia representativa, que pressupõe eleições livres para a escolha dos representantes do povo também acabou por encontrar muitas variações e nuances no campo da política.

Paul Ricoeur compreende que esse cenário político começa a se desenhar dessa forma também pela ampliação da classe média. A princípio, o ideal democrático de fazer prevalecer a vontade da maioria só se conservou como um valor progressista "enquanto a própria maioria representou a conjunção entre explorados e a parte esclarecida da opinião ávida de mudança, de liberdade e de justiça" (RICOEUR, 1977, p.154). Quando, no entanto, aquilo que se entende como maioria, passa a ser uma classe média que se põe em defesa de suas aquisições e resistente às mudanças, o quadro passa a ser outro. Assim é que, no contexto europeu, surge algo como a reivindicação por uma democracia direta e o fim da classe política. Isto é algo que supõe a vigência da "experiência selvagem", nas palavras de Ricoeur. Essa experiência encaminharia toda uma sociedade para a "ausência de projeto coletivo, para o afrouxamento das normas e para o esquecimento das heranças" (idem). Diante disso, Ricoeur temia um furor destrutivo pela ânsia de poder.

\footnotetext{
Esquece-se, então, que a democracia política foi uma conquista muito laboriosa e bastante frágil, baseada em sutis procedimentos de discursos e em convenções complexas de arbitragem dos conflitos. Alguém já dizia: "a democracia é o procedimento". E é verdade. (RICOEUR, 1977, p. 155)
}

Segundo Ricoeur, o que se configura nas sociedades democráticas atuais é uma separação dos valores revolucionários em prioridades dentro de projetos políticos distintos. Dessa forma, como observa Souza, o que parece ter ocorrido é que:

Juntamente à fraternidade, liberdade e igualdade foram unidas e cantadas em verso e prosa como ideais revolucionários. Mais tarde foram seccionadas como ideais de 
revolucionários distintos e, por fim, opostos. A liberdade como ideal da revolução burguesa e do liberalismo político. Já a igualdade seria um ideal da revolução proletária e do pensamento socialista. Liberdade, uma reivindicação à direita. Igualdade, à esquerda. (SOUZA, 2005, p.279)

Diante de tais circunstâncias Gadamer nos leva a compreender supor que esse estado de coisas nos requisita uma reflexão acerca de nossa própria situação. Dessa forma, Gadamer questiona como algo como a tolerância é possível numa época como esta em que o espaço para a reflexão e para a busca por sentido encontra-se tão restrito. Para Gadamer, não há um déspota a ser destronado, porém, vivemos todos a serviço de um tipo de poder: o da racionalização e funcionalização de todas as áreas da vida. Com isso, o que encontramos, quando buscamos um sentido que unifique nossas experiências, são unidades fechadas e absolutamente autônomas, que pouco dialogam entre si:

\begin{abstract}
Atualmente se diria que o mero perscrutar das ciências em todas as direções, que permite a realização de suas ideias metódicas, deixa insatisfeita uma necessidade última da razão, ou seja, a de manter a unidade do todo anterior. (...) Uma das consequências da técnica é o de haver conduzido a uma tal manipulação da sociedade humana, da opinião pública, das formas de vida de todos nós que, às vezes, chega-se a perder o alento. A metafísica e a religião parecem haver oferecido melhores pontos de apoio para as tarefas de ordenação da sociedade humana que o poder acumulado pela ciência moderna. (GADAMER, 1983, p.10)
\end{abstract}

Gadamer não está, contudo, pregando a volta dos antigos dogmas. Esta é a tradição em que nos encontramos e não há como desvincularmos de nossa compreensão a sobrevivência e o questionamento de todos os preconceitos que dela herdamos. São esses mesmos preconceitos que nos conduzem no campo político. O que Gadamer parece dizer é que, nessa época de administração racional da sociedade, a tolerância já não tem mais o lugar privilegiado que tinha anteriormente. A mulher, o negro, o homossexual, os excluídos em geral, não querem mais a tolerância e a benevolência de uma espécie de soberano virtuoso, eles querem, na verdade, participar do poder que administra suas vidas, tomar parte no exercício de um poder que é impessoal. Não é em solidariedade que se apoia a administração tecnocrática da sociedade, mas no cálculo. Segundo Gadamer, é como se a época de construção desse tipo de solidariedade tivesse passado. Desse modo, a tolerância converte-se, como afirma Gadamer, numa tarefa e ao mesmo tempo a mais rara das virtudes. 


\section{3.}

\section{Experiência estética: como ela se relaciona com a ética?}

É diante de uma situação histórica de imensurável racionalização da vida social e de uma angustiante perda de sentido que algo como a experiência estética começa a se mostrar cada vez mais como uma possibilidade de orientação para a formação ética. A necessidade de resensibilização dos sentidos e a busca por uma lida mais próxima com aquilo que a metodologização da vida deixou escapar é o que tem feito estudiosos na área da educação buscarem na experiência estética a abertura para o questionamento acerca da vida ética. Isso porque, como afirma Hermann:

A educação depara-se com questões relativas ao modo de viver - a ética, portanto. Essa preocupação, originalmente filosófica, será central para a questão educacional, trazendo um diálogo interminável entre as teorias pedagógicas e a Filosofia, no sentido de dar uma direção ao processo educativo, definir quais ideias de bem historicamente são entendidas como válidas e que exigências de reciprocidade podemos nos fazer quanto ao cumprimento das normas. (HERMANN, 2010, p. 21)

Desse modo, a educação não pode se privar desse autoquestionamento, uma vez que ela se propõe a formar o ser ético dos indivíduos de acordo com aquilo que a tradição na qual se inserem compreende por agir de modo justo, questionando, inclusive, estas mesmas orientações. Assim, todo modelo de educação que não se questiona a respeito de suas próprias orientações éticas, acaba por naturalizar normas vigentes, restringindo seus horizontes e limitando os espaços para transformação. Como consequência disso temos, mais uma vez, a mera reprodução alienada e carente de sentido de práticas que dificilmente irão despertar nos indivíduos alguma reflexão acerca de sua atuação no mundo.

Hermann (2005) faz a observação de que a aproximação entre ética e estética é algo que, contudo, parece fugir do convencional, uma vez que o que acabou ocorrendo na tradição moderna foi a quase que completa segregação entre aquilo que correspondia ao âmbito moral, cognitivo e estético. Até mesmo no pensamento grego, em que havia uma convergência entre o belo e o bom, entre o sensível e o intelectual, a relação entre a ética e a estética não é algo evidente. Apensar dessa aproximação se mostrar frutífera: 
Deve-se notar, contudo, que essa relação tem, no seu desenvolvimento histórico, um caráter paradoxal, pois a estética aparece no início do pensamento como algo oposto à ética. Em Platão, o mundo sensível não produz o verdadeiro conhecimento, ao contrário, a eikasía é o primeiro grau do conhecimento e se refere a uma cópia ou simulacro da coisa sensível. Nesse sentido, a arte oculta o verdadeiro, produz uma espécie de ilusão e não pode melhorar o homem, o que leva Platão a considerar inadequado deixar com os poetas a responsabilidade pela educação. Até o século XIX, a estética fica associada ao culto da aparência, à superficialidade, o que provoca reprovação da moral burguesa. A partir dos esforços teóricos de Kant e Schiller, torna-se possível pensar a estética como um modo de sensibilidade para a vida moral. (HERMANN, 2005, p.11)

Como observa a autora, é interessante perceber que existe um entendimento de que a experiência sensível é passível de enganos, portanto, que não devemos confiar somente nos nossos sentidos, uma vez que estes são enganosos e podem nos iludir. A ideia é a de que, sem o uso do intelecto, corremos o risco de nos deixarmos levar pelas aparências e não conseguirmos perceber com clareza aquilo que pode estar por trás da experiência sensível imediata. Para Hermann, de acordo com essa ideia, a experiência sensível, deveria receber um estatuto inferior quando comparada com a razão, uma vez que não pode por si só conhecer com certeza aquilo que experimenta e, portanto, não pode jugar sua experiência como verdadeira ou falsa.

O que Hermann, em contraposição a isso, defende é a possibilidade de uma experiência estética tornar aquele que a experimenta, mais aberto para ver as coisas em seus diferentes perfis. O surgimento de uma sensibilidade filosófica mais favorável à estética tem início, segundo a autora, com Schiller, e se acentua no século XIX com Schelling, Schopenhauer e, sobretudo, Nietzsche, Heidegger e Gadamer que atribuem à arte um papel central para a elucidação da compreensão humana, mas principalmente para sua ampliação. Por isso, Hermann ressalta esse entrelaçamento entre estética e ética e aborda as potencialidades que a estética oferece à formação ética. Não temos a intenção nesse estudo de nos aprofundarmos na genealogia da tensão entre estética e ética. Por isso, nos ateremos aqui à questão de como essa temática se articula na obra de Gadamer. De acordo com a hermenêutica gadameriana:

Todos esses conceitos, como imitação, aparência, desrealização, ilusão, magia, sonho pressupõem uma relação com um ser verdadeiro, do qual se diferencia o ser estético. No entanto, o retorno fenomenológico à experiência estética ensina que esta não pensa, de forma alguma, com base nessa relação, mas, antes, naquilo que ela experimenta, vê a genuína verdade. A isso corresponde o fato de que a experiência estética, por natureza, não pode ser enganada por uma experiência 
genuína de realidade. Ao contrário disso, o que caracteriza todas as modificações da experiência da realidade é que a estas corresponde, por necessidade de sua natureza, uma experiência de engano. O que era aparente, se desvenda, o que foi desbalizado, torna-se real, o que era magia, perde sua magia, o que era ilusão, abrese à vista, o que era sonho, disso nós despertamos. Se a estética fosse aparência, nesse sentido, sua validade poderia então - tal como os horrores do sonho somente exercer seu domínio enquanto não se duvidasse da realidade do fenômeno, já que iria perder sua verdade ao despertarmos. (GADAMER, 1997, p.150)

Nesse sentido, a experiência estética não pode ser tomada como um mero engano dos sentidos, isto é, como uma ilusão que se desfaz quando descobrimos a realidade. Tampouco ela pode ser tomada como uma imitação de algo mais originário. Para Gadamer, a obra de arte, na dinâmica de sua própria apresentação é capaz de nos dizer algo verdadeiro sobre o mundo. Isso porque a experiência estética não implica a relação sujeito e objeto, em que se põem em jogo faculdades subjetivas. A experiência estética, mais precisamente, a "experiência da arte" sempre abrange intérprete e obra, de tal modo que o nosso ser histórico sempre se sobrepuja a nossa subjetividade. Portanto, como Hermann observa, Gadamer "refaz o movimento constitutivo da experiência estética, que não se esgota na subjetividade, nem na objetividade, mas se dá na e com a experiência" (HERMANN, 2010, p.49). O que se aproxima da ampliação de horizontes descrita por Gadamer, como vemos na passagem a seguir:

Pois que na consciência estética encontramos as feições que caracterizam a consciência formada: elevação à universalidade, distanciamento da particularidade da aceitação ou rejeição imediata, deixar e fazer valer aquilo que não corresponde à própria expectativa ou a própria preferência. (GADAMER, 1997, p.151)

A questão que levantamos inicialmente a respeito da formação de uma razão crítica capaz de distinguir preconceitos que nos auxiliam na compreensão dos que devem ser superados encontra na experiência estética um campo fundamental. Vemos que a aproximação de Hermann com os escritos de Gadamer tem como principal interesse o que o filósofo denominou como sendo o encontro consigo mesmo que a compreensão de uma obra de arte é capaz de promover. O que abre a possibilidade da experiência de um autoquestionamento diante da alteridade e da diferença que pode ser transposta para a educação. Como observa Hermann:

Nessa perspectiva, a experiência estética adquire outro nível conceitual por meio da hermenêutica de Gadamer, que não a entende como um acontecimento subjetivo, mas como uma práxis, em que sujeito e objeto são interligados. O conceito de experiência estética abandona a imagem de um objeto inerte, passando para os 
processos de apropriação, julgamento, emprego e transformação que se dirigem sobre esse objeto. (HERMANN, 2010, p.52)

A experiência estética pode inclusive ser comparada à experiência de mundo em geral, que não é operada por uma subjetividade, mas por nossa compreensão de mundo, construída em nossa tradição e que nos orienta desde o momento em que nos encontramos inseridos nela. Desse modo, a compreensão não pertence à subjetividade do intérprete, mas ao ser daquilo que é compreendido. As possibilidades de se compreender uma coisa estão nas próprias possibilidades interpretativas que elas liberam. Elas não são unicamente do indivíduo que interpreta, mas encontram-se difundidas no horizonte compreensivo de sua tradição e se instanciam na obra. Desse modo, Gadamer afirma que:

A obra de arte tem, antes, o seu verdadeiro ser em se tornar uma experiência que irá transformar aquele que a experimenta. O "sujeito" da experiência da arte, o que fica e persevera, não é a subjetividade de quem a experimenta, mas a própria obra de arte. (GADAMER,1997, p.175)

Justamente nesse ponto é que o intérprete e obra fundem seus horizontes e a interpretação pode então revelar algo não só da obra, mas também do próprio intérprete. Os efeitos que a obra provoca naquele que a interpreta afloram e revelam algo que está presente em sua compreensão e podem, então, culminar numa autocompreensão e num autoquestionamento. $\mathrm{O}$ incômodo ou a satisfação que a experiência artística pode provocar, tem por isso um potencial didático, pois promove naquele que a vivencia um encontro com as questões relativas ao seu modo de agir, suas crenças e seus valores, ou seja, com o seu ser ético. Esse encontro requisita que se coloquem em jogo as orientações prévias de mundo, tornado-as conhecidas para o próprio intérprete que experimenta o caráter temporal desses preconceitos e seus efeitos em nosso mundo.

Dessa forma, Gadamer considerou que é possível circundar o contexto histórico da criação artística, e a própria história de vida do autor de uma obra, para tentar encontrar o que ela expressa, contudo, ainda assim isso não é o que há de mais essencial na interpretação. Para Gadamer, a "relação estabelecida entre a obra como um mundo e o meu mundo" é onde se dá a experiência artística. Isso porque "o que acontece na interpretação da obra é uma fusão, um diálogo, um confronto de mundos" (GADAMER, 1997, 402). Assim, Gadamer descreve essa 
experiência como algo sempre original, que se dá a cada vez de um modo diverso e que se retemporaliza e se enriquece a cada vez. Toda vez em que fundimos horizontes com uma obra, ela se apresenta de um modo diverso. Por isso, Gadamer afirmou que:

\begin{abstract}
Uma vez que encontramos no mundo a obra de arte e em cada obra de arte individual um mundo, este não continua a ser um universo estranho em que, por encantamento, estamos à mercê do tempo e do momento. Nele, mais do que isso, aprendemos a nos compreender, e isso significa que suspendemos a descontinuidade e a pontualidade da vivência na continuidade da nossa existência. O que importa, por isso, é chegar a um ponto de partida, com relação ao belo e à arte que não pretenda a imediaticidade, mas que corresponda à realidade histórica do homem. (GADAMER, 1997, p.168)
\end{abstract}

Não podemos perder de vista que em Verdade e Método I a tematização da experiência com a obra de arte, contrapõe-se à concepção científica de verdade, obtida através da aplicação racional do método científico, que assegura, dentre outras coisas, a possibilidade de reproduzir em um ambiente controlado aquilo que se obtém em sua investigação. Gadamer, por sua vez, está interessado em investigar a experiência de verdade que temos no encontro com a obra. Essa experiência que escapa a qualquer tentativa de controle metódico, mas que nem por isso se mostra menos verdadeira. Por conta disso, Gadamer elabora as seguintes questões:

Será que não deve haver nenhum conhecimento na arte? Não há na experiência da arte, uma reivindicação à verdade, que sendo certamente diversa da ciência, certamente também não lhe será inferior? E será que não reside a tarefa estética, justamente em fundamentar que a experiência da arte é uma forma de conhecimento dos sentidos, que transmite à ciência os últimos dados, a partir dos quais põe-se a construir o conhecimento da natureza, certamente também diferente de todo conhecimento ético da razão e, aliás, de todo o conhecimento conceitual, mas que é contudo, ou seja, transmissão de verdade? (GADAMER, 1997, p.169)

Uma vez que a hermenêutica em sua determinação originária é “a arte de esclarecer e transmitir, através de um esforço próprio de interpretação, aquilo que os outros nos dizem, o que encontramos na tradição, e que não é compreensível de imediato" (GADAMER, 2012, p.215), a obra de arte torna-se então seu objeto. Para Gadamer, o encontro entre estética e hermenêutica reside, então, no fato da obra de arte nos dizer algo decisivo para nossa compreensão de mundo. Assim, o fenômeno da obra de arte, como experiência estética, que tornam-se objeto da 
hermenêutica. Justamente porque, como algo que nos comunica, a obra de arte encontra-se ao lado de tudo aquilo buscamos compreender. Assim, Gadamer, em diálogo com autores de diferentes tradições, empreende uma longa investigação sobre uma vasta literatura tomou o fenômeno da obra de arte como objeto. Ele faz uma detalhada exegese das reflexões sobre a estética com o objetivo principal de fazer uma crítica do subjetivismo na estética, ou como ele mesmo diz, de realizar uma "dessubjetivação da experiência". Gadamer chama a atenção sobre os efeitos de tais compreensões em nossa tradição e, colocando em jogo seus pressupostos, observa o quanto elas contribuem ou obscurecem a interpretação sobre o fenômeno.

Nesse sentido, Gadamer aproxima-se de Hegel, que compreendeu a "arte como uma das configurações do espírito absoluto", de acordo com o que se concebe a obra de arte como "uma forma de autoconhecimento do espírito, onde não entra nada de estranho, de insolúvel, nenhuma contingência do real" (2012, p.212). Segundo Gadamer, "é a própria obra de arte que se comunica a si mesma" (idem), por isso, mais uma vez, a realidade que se apresenta na obra de arte, não se restringe ao seu horizonte histórico de origem, onde o artista e o observador eram contemporâneos. A verdade que a obra pode expressar transcende seu contexto de origem. Novamente, a hermenêutica enxerga no encontro com a obra de arte um processo de integração. Assim como um texto escrito, que deseja ser compreendido para além de seu horizonte histórico de origem, também a obra de arte deve poder dizer algo naquele horizonte histórico em que se apresenta para ser experimentada. Assim, Gadamer nos diz que:

Dentre as tarefas impostas à vida humana, enraizadas nos legados da tradição, podemos contar, sobretudo com a arte, dentro de um processo de integração. Sim, é de se perguntar, inclusive, se a atualidade específica da obra de arte não consiste precisamente em criar abertura ilimitada em vista de sempre novas integrações. (GADAMER, 2012, p.212)

Por isso, a obra de arte "fala à pessoa não apenas no modo como um documento histórico fala ao historiador, por exemplo - ela fala a cada um algo como se fosse algo próprio dele, como algo presente e contemporâneo" (GADAMER, 2012, p.218). Aqui, a hermenêutica encontra então a tarefa de compreender o sentido daquilo que a obra de arte diz e, então, tornar esse sentido compreensível para si e comunicável para o outro. 
Além disso, de acordo com Gadamer, "toda a interpretação do compreensível, que busca auxiliar os outros a compreenderem, tem o caráter de linguagem" (ibid, p.216). Isto é algo que coloca mais uma vez em evidência tanto a "legitimidade do ponto de vista hermenêutico frente à experiência da arte", quanto "a questão relativa à linguagem da arte" (idem). O autor ainda afirma que:

Veremos que nisso reside uma consequência hermenêutica de longo alcance, na medida em que todo encontro com a linguagem da arte é um encontro com um acontecimento não acabado e, ela mesma, uma parte desse acontecimento. É a isso que se tem de por em relevo contra a consciência estética e contra a sua neutralização da questão da verdade. (GADAMER, 1997, p.171)

A moderna consciência estética defende, em última análise, que a experiência com a obra de arte diz respeito a vivências pessoais do sujeito e não à verdade, não a algo que se possa comunicar. Uma obra de arte, portanto, não diria algo a respeito do mundo, não apresentaria nada que transcendesse a experiência particular e individual do autor e a do receptor. Assim, Gadamer entende que a busca sobre a questão da verdade na obra de arte não poderá se dar pelo viés de uma consciência estética, ou seja, pela experiência individual e subjetiva de cada indivíduo. Também não se poderá tomar a obra de arte como um objeto acabado, que já comporta em si toda e qualquer possibilidade de interpretação. Essa busca se dará nos termos de uma experiência de abertura, algo que acontece no entre o pretenso sujeito e a obra, e que nunca se esgota totalmente. Para Gadamer, somente assim, será possível compreender melhor a verdade que nos vem ao encontro na experiência estética. A potencialidade didática desse encontro com a obra de arte, portanto, está justamente na experiência aberta que ele promove. Como nos fala Hermann:

A experiência (Erfahrung), na perspectiva hermenêutica, expressa uma vivência, pela qual aprendemos. Não se trata de um fluxo de percepções, mas de um acontecimento, de um encontro, um processo revelador que descobre a realidade como um acontecer. (HERMANN, 2010, p.115)

Essa concepção de experiência é radicalmente distinta da experiência científica, que pressupõe a busca de uma verdade universal, atemporal, e também sua reprodutibilidade pelos procedimentos metódicos. Muito pelo contrário, nessa concepção, compreende-se que esse é um processo que não pode se orientar por um ideal de completude e, embora ele possa ser comunicado, não pode ser reproduzido metodologicamente. A experiência que a obra de arte é capaz de 
promover é, por isso, sempre imponderável. Assim, como no encontro entre duas pessoas, o diálogo que se estabelece não pode ser previsto em seus resultados e nem ser objetivamente reproduzido posteriormente. Todo diálogo é um acontecimento único. Gadamer também, por isso, considerou que a própria análise da consciência da história efeitual tem a estrutura da experiência. Isso porque existe uma historicidade interna em toda experiência, que compreende os efeitos históricos e que faz a mediação entre a totalidade da tradição e o presente. A objetividade metodológica que também se intitula de experiência, por outro lado, atua exatamente no sentido de eliminar essa historicidade. Como observa Gadamer:

\begin{abstract}
O escopo da ciência é objetivar a experiência até que fique livre de qualquer momento histórico. No experimento natural-científico consegue-se isso através do modo de seu aparato metodológico. Algo parecido realiza também o método histórico-crítico nas ciências do espírito. Num e noutro caso a objetividade ficaria garantida pelo fato de que as experiências que jazem ali poderiam ser repetidas por qualquer pessoa. Tal como na ciência da natureza os experimentos têm de ser possíveis de comprovação posterior, também nas ciências do espírito o procedimento completo tem que ser passível de controle. Nesse sentido, na ciência não pode restar lugar para a historicidade da experiência. (GADAMER, 1997, p.513)
\end{abstract}

Contudo, podemos aqui nos perguntar se até mesmo nas ciências da natureza, a escolha metodológica também não requisitaria um saber histórico. $\mathrm{O}$ que orienta a escolha metodológica e possibilita seu avanço técnico é justamente a possibilidade dessa experiência, que conhece seus efeitos. Assim, é a experiência que assegura através de observações regulares que, por exemplo, "um determinado meio curativo tem um determinado efeito" (GADAMER, 1997, p.518). Desse modo, ela é capaz de encontrar regularidades e superar percepções individuais em busca de conceitos mais gerais.

Hermann chama ainda a atenção para o fato de que, na filosofia de Gadamer, o que interessa também "reter da ideia de experiência dialética é a estrutura de inversão, que traz consigo a negatividade" (ibid, p.116) Essa negatividade acontece quando, diante de uma determinada experiência, nossas concepções prévias se frustram e nos deparamos com o fato de que aquilo que havíamos antecipado em nosso juízo não parece mais tão verdadeiro. Ou seja, "nos damos conta de que não é aquilo que tínhamos pensado, não é o que havíamos suposto" (idem). Reformulamos, então, a partir dessa negatividade, 
nossos projetos prévios e novamente nos colocamos a caminho de compreender aquilo que se apresenta. Assim, Hermann nos diz que:

Quando a consciência avança nisso e faz a volta é que ela se faz consciência, ou se faz unidade consigo mesma - sabe-se a si mesma. A experiência então conhece o estranho, o outro. Nesse esquema, ela é sempre superação, porque rompe com generalidades e inércias. Não se trata também de uma experiência que ensina isto ou aquilo, mas da experiência que incide sobre nosso inacabamento. (HERMANN, 2010, p.116)

O encontro com a alteridade é o que pode enriquecer a nossa compreensão, uma vez que nesse encontro nos deparamos com a insuficiência de nossos preconceitos para compreender algo e assim aprendemos com o outro. Por isso, Gadamer afirmou que "a experiência pressupõe necessariamente que se desapontem muitas expectativas, pois somente é adquirida através disso" (GADAMER, 1997, p.525). Sobre esse processo, não temos nenhum controle, pois ele é o modo próprio como toda formação se dá. Por outro lado, não podemos negar que esse processo requisita a abertura de quem o empreende. Mesmo na experiência artística, a revisão de projetos prévios pode não acontecer. Nesse sentido, assim como em qualquer experiência de diálogo, o outro se encontrará formalmente privado de sua pretensão de dizer alguma verdade.

\subsection{1. \\ O conceito de jogo: por que Gadamer considerou o jogo como o modo próprio de ser da obra de arte?}

Jogo não significa aqui o comportamento ou muito menos o estado de ânimo daquele que cria ou daquele que usufrui e, sobretudo, não significa a liberdade de uma subjetividade que atua no jogo, mas o próprio modo de ser da obra de arte. (GADAMER, 1997, p.174)

Gadamer nos fala que é o modo de ser da obra de arte o que será para ele objeto de investigação e esse modo de ser é caracterizado como jogo. Portanto, a experiência que temos com a obra de arte é uma experiência de jogo. Primeiramente, a obra de arte não é um objeto entre outros que têm uma finalidade específica que determina seu uso. Na visão do autor, “encontra-se aí justamente o ponto em que o modo de ser do jogo se torna significante, pois o jogo tem uma natureza própria, independente da consciência daqueles que jogam.” (GADAMER, 1997, p.176). É o jogo que joga a si mesmo, ou seja, é ele 
que orienta e determina a medida correta de cada jogada. Nesse sentido, é o jogo que é jogado (sich abspielt) nisso - não há um sujeito fixo que esteja jogando ali. O jogo é a consumação do movimento como tal" (ibid, p. 177). Essa é uma afirmação que contraria qualquer ideia de subjetividade, de que somos nós que escolhemos qual movimento faremos a cada jogada e que conhecimentos prévios utilizaremos para compreender o que a obra de arte nos diz. Na leitura de Gadamer, essa escolha independe de qualquer controle ou ponderação de uma possível subjetividade do indivíduo. No momento em que nos colocamos diante de uma obra e nos dispomos a compreendê-la, o movimento do jogo se realiza por si só. Até mesmo quando consideramos que estamos recorrendo a essa ou aquela ideia para compreender, essa consideração já é tardia com relação a nossa disposição. Ela só surge como possibilidade porque o jogo faz com que ela surja.

O movimento do jogo é para Gadamer, determinado pela repetição "o movimento de vaivém é obviamente tão central para a determinação da natureza do jogo que chega a ser indiferente quem ou o que executa esse movimento". (idem). Por isso, para ele, esse movimento não pode ser determinado de antemão, assim como seus resultados. Gadamer nos fala que "todo jogar é um ser-jogado. $\mathrm{O}$ atrativo do jogo, a fascinação que exerce, reside justamente no fato de que o jogo se assenhora do jogador" (1997, p.181). Quando o jogo se realiza, aquele que se encontra no jogo tem todos os seus movimentos determinados por ele. Gadamer, entende que no jogo ${ }^{32}$ realizado pelas crianças, é esse movimento a verdadeira finalidade do jogo e não a sua solução.

Cada jogo coloca uma tarefa ao homem que o joga. Não pode igualmente abandonar-se à liberdade do colocar-se em jogo, a não ser através da transformação dos fins do seu comportamento em simples tarefas do jogo. É assim que a criança estabelece para si mesma sua tarefa num jogo com bola, e essas tarefas são tarefas do jogo, porque o verdadeiro fim do jogo não é, de forma alguma, a solução dessas tarefas, mas a regulamentação e a configuração do próprio movimento do jogo. (GADAMER, 1997, p.183)

Num espetáculo artístico, o espectador também estabelece com as cenas de uma apresentação uma relação de jogo. Diante de uma peça teatral, por exemplo, aquele que assiste realiza um constante movimento de projetar e reprojetar o

\footnotetext{
${ }^{32}$ Fazemos aqui uma observação a respeito do quão polissêmica é a palavra jogo (Spiel) em alemão. Jogar quer dizer competir esportivamente, brincar, tocar, atuar etc. Jogo é um peça de teatro, uma partida de futebol, uma brincadeira de criança etc.
} 
sentido daquilo que aparece. Assim, na experiência artística, quando bem sucedida, o jogo se assenhora daqueles que participam. Contudo, nesse caso, o jogo acontece de um modo bastante específico, como descreve Gadamer:

Mesmo um espetáculo continua sendo um jogo, isto é, tem a estrutura do jogo, estrutura de ser um mundo fechado em si mesmo. Mas o espetáculo cúltico ou profano, por mais que seja um mundo fechado em si, que o representa, é como que aberto para o lado do espectador. Somente nele é que ganha o seu inteiro significado. Como todo jogo, os atores representam seus papéis, e assim o jogo torna-se representação, mas o próprio jogo é o conjunto dos atores (Spielern) e espectadores. De fato, experimenta de modo mais próprio, aquele, e representa-se do modo como é "intencionado", àquele que não participa no jogo, mas assiste. Neles, o jogo (representação) é alçado igualmente à sua idealidade. (...) Naturalmente, isso não quer dizer que também o jogador (ator) não poderá vir a experimentar o sentido do todo em que ele, representando desempenha seu papel. $\mathrm{O}$ espectador tem somente uma primazia metódica: pelo fato de o jogo ser realizado para ele, torna-se visível que possui em si um conteúdo de sentido, que deve ser entendido e que, por isso, é separável do comportamento do jogador (ator). (GADAMER, 1997, p.186)

O espetáculo é um mundo fechado em si onde os jogadores são os atores que desempenham seus papeis. Contudo, é justamente no lado em que o espetáculo é aberto para o espectador é que o jogo alcança seu completo significado. Isso porque o espetáculo é encenado para alguém. Ele diz algo para o público. Desse modo, também o público faz parte do jogo e desempenha um papel específico. Ele não atua no jogo como os atores, mas é nesse lado aberto do espetáculo que tudo aquilo o que é intencionado pode se tornar visível de forma mais completa. Gadamer, embora considere que também os atores possam experimentar esse sentido, o espectador teria uma "primazia metódica". Podemos aqui considerar que, por sua posição privilegiada, por se encontra diante do espetáculo, o espectador teria uma melhor visão do todo. Uma vez que o espetáculo é encenado para ele, não existiria nenhuma parte oculta na narrativa. Nenhum detalhe daquilo que se apresenta, está fora de seu campo de visão.

Assim, Gadamer compreende que no momento em que o jogo se estabelece, os jogadores não são mais os protagonistas. Quem ganha vida e se apresenta é o que é jogado por eles. Isso porque “o jogo ele mesmo, é de tal maneira uma transformação que para ninguém continua a existir a identidade daquele que joga (representa). Todo mundo passa apenas a se perguntar o que vem a ser isso, o que é que isso "quer dizer"” (ibid, p.189). Nessa experiência, nos deparamos com aquilo que a obra nos diz e, então, buscamos interpretar o compreendido na obra. 
Aqui vemos que Gadamer mais uma vez coloca a questão da pergunta. No momento em que o jogo se estabelece e que ninguém (nenhuma identidade) mais encontra-se fora dele o que ocorre é um jogo de perguntas e respostas. Isso porque, para o autor "em toda experiência encontra-se pressuposta a estrutura da pergunta. Não se fazem experiências sem a atividade de perguntar." (GADAMER, 1997, p.534). Mais uma vez, Gadamer recorre ao modelo da dialética platônica e afirma que a pergunta pode colocar em curso a negatividade dialética da experiência, que culmina na sua radicalização que é o "saber que não se sabe" (idem), a famosa douta ignorância, de Sócrates. Contudo, quando perguntamos: o que isso quer dizer? O sentido de tal pergunta já tem, em grande medida uma orientação sobre o que é possível que essa coisa seja. Mesmo que essa orientação se frustre, e que tenhamos que voltar ao início, a nova orientação será readequada ao que experiência já nos deu de conhecimento sobre o que a coisa não é.

Para tornar mais claro esse jogo de perguntas e respostas que se estabelece na experiência com a obra de arte, podemos recorrer ao que Gadamer observou sobre os diálogos platônicos. Isso porque, segundo o autor, eles conseguem mostrar que "perguntar é mais difícil do que responder" (1997, p.534), diferente do que se possa comumente supor. Isso se torna ainda mais flagrante quando, os companheiros de diálogo de Sócrates, tentam lhe devolver a pergunta, reivindicando para si uma posição que supostamente seria a mais cômoda. Gadamer observa que é justamente nesse momento que eles fracassam de forma mais explicita. Gadamer cita como exemplo o diálogo entre Sócrates e Protágoras, em que Sócrates se diz incapaz de acompanhar longas respostas e pede para que Protágoras seja mais conciso. Protágoras, então, pergunta: “e a critério de quem ficará decidir sobre o tamanho de minhas respostas, ao meu ou ao teu?" (PLATÃO, PROTÁGORAS, 334e). A pergunta acaba por deixar transparecer o que Protágoras reconhece logo em seguida. Protágoras diz a Sócrates que, caso alinhe o tamanho de suas respostas às possibilidades de seus opositores, não terá sobre eles vantagem alguma. Assim, Gadamer percebe que:

Por trás desse motivo comediográfico dos diálogos platônicos não é difícil descobrir a distinção crítica entre discurso autêntico e inautêntico. Aquele que no falar só procura ter razão e não procura a clarividência das coisas, considerará certamente que é mais fácil perguntar do que dar resposta. (GADAMER, 1997, 535) 
Perguntar é colocar algo em aberto e, desse modo, todo o saber passa pela pergunta. Aquele que credita ter compreendido uma obra de arte e, por isso se coloca a falar sobre ela, ainda poderá realizar novas perguntas sobre esse compreendido e encontrar outras respostas. Nas palavras de Gadamer "o perguntado tem de pairar no ar frente a qualquer sentença constatadora e decisória" (idem). O que significa dizer que a coisa deve "aparecer" diante daquilo que falamos sobre ela. No jogo de perguntas e respostas que a dialética realiza, o perguntado deve surgir e orientar aquilo que se pode ou não dizer sobre ele.

É interessante observar que para Gadamer, esse é o modo de ser da pergunta autêntica: a que se orienta pelo perguntado e o faz surgir a cada sentença. Para o autor, existe, contudo pelo menos duas formas de pergunta inautêntica: a pedagógica e retórica. Na primeira não existe quem pergunta. Não há um verdadeiro interesse investigativo e aquele que a faz não tem em vista nenhuma abertura. Uma vez que ele já conhece de antemão a resposta que deverá encontrar, a pergunta apenas se adéqua ao já sabido. Desse modo, não há como surgir uma nova resposta. Já a pergunta retórica, para Gadamer, nem pode ser tomada de fato como uma pergunta. Nesse caso, "não somente não há quem pergunte, mas nem sequer há algo realmente perguntado" (1997, p.536).

Gadamer, também considerou que a abertura da pergunta não é sem limites. Existe para ela uma um horizonte ao qual ela se vincula e sem o qual ela não parte e nem chega a lugar algum. A pergunta revela, na verdade, que uma abertura existe e que nessa abertura cabe uma pergunta. Por isso ela deve ser colocada nessa abertura e revelar a existência de um espaço para descoberta. Revelar que algo se mostra ainda passível de questionamento. Nas palavras de Gadamer:

Entretanto, a abertura da pergunta não é ilimitada. Nela está contida uma certa circunscrição, através do horizonte da pergunta. Uma pergunta sem horizonte acaba no vazio. Ela só se torna uma pergunta quando a fluida indeterminação da direção a que aponta é colocada na determinação da direção de um "assim ou assim": dito de outra maneira, a pergunta tem de ser colocada. A colocação de uma pergunta pressupõe a abertura, mas também uma limitação. Implica uma fixação expressa dos pressupostos que estão de pé, a partir dos quais mostra-se o questionável, aquilo que permanece ainda aberto. (GADAMER, 1997, p.536)

Assim, também a colocação da pergunta também pode se mostrar arbitrária. Quando esta não encontra um terreno verdadeiramente aberto, ela parte de falsos pressupostos e se funda neles. Desse modo ela já não se orienta mais pela coisa, 
mas por aquilo eventualmente tomou como sendo uma verdade sobre ela. Fatalmente essa pergunta "tortuosa", como nos fala Gadamer, que perdeu a sua orientação inicial e seguiu pistas falsas, não obterá uma resposta na própria coisa.

Voltando ao exemplo do jogo de perguntas e respostas que se estabelece ao assistir a um espetáculo, aqui, mais uma vez, vemos que um espetáculo não realiza um falseamento da verdade, ou uma mera imitação da verdade. O espetáculo, assim como toda obra de arte, como um texto literário, nos diz algo e revela em si a sua própria abertura. Para que alcancemos aquilo que nos diz a obra, precisamos conseguir formular as perguntas adequadas a essa abertura. Por isso, mais do que nos dar respostas, a experiência estética pode nos ensinar a perceber a abertura e a colocar as perguntas de forma apropriada.

A ideia de imitação, não é de todo descartada por Gadamer, desde que não se perca de vista todo conhecimento original que existe na imitação. Não no sentido de que algo de mais verdadeiro esteja por trás de uma imitação, ou que a sustente. Na realidade, a imitação deve apresentar o que é de tal ou tal forma pelo modo como isso se apresenta. Assim, Gadamer fala que:

O conceito de imitação, porém, só consegue descrever o jogo da arte, se não se perder de vista o sentido do conhecimento, que se encontra na imitação. Aí, encontra-se o que é representado - é a relação mímica originária. Quem imita alguma coisa deixa isso ser aí o que ele conhece e como o conhece. É imitando que a criança começa a brincar, fazendo o que conhece e confirmando assim a si mesma. Também o prazer com que as crianças se fantasiam, a respeito do que já se manifesta Aristóteles, não pretende ser um esconder-se, uma simulação, a fim de que se adivinhe e se reconheça quem está por trás disso, mas, ao contrário, um representar, de tal modo que apenas o representado é. Por nada desse mundo a criança vai querer ser adivinhada por trás de sua fantasia. O que ela representa deve ser, e se há algo que deva ser adivinhado, é exatamente isso. Terá de ser reconhecido o que ali está. Dessa ponderação há algo a fixar: o sentido do conhecimento da mimesis é reconhecimento. (GADAMER, 1997, p. 191)

É curioso observar que, para Gadamer, a criança na brincadeira de imitar, confirma a si mesma aquilo que ela conhece. Na brincadeira, ela coloca em jogo o modo como compreende seu mundo, experimenta as relações de sentido que se estabelecem e as representa na imitação. Assim, aquilo "o que ela representa deve ser, e se há algo que deva ser adivinhado, é exatamente isso" (idem). Por isso, em meio à fantasia e às soluções mágicas que a brincadeira permite, na imitação da criança vemos aquilo que ela compreende de seu mundo. 
$\mathrm{Na}$ imitação, aquele que imita precisa conseguir extrair e mostrar em sua representação a essência de algo. Uma vez que "quem imita tem de deixar algo fora ou realçar algo" (ibid, p.193) e exagerar na medida em que ele o mostra. Assim, aquilo que aparece na imitação toma necessariamente uma distância do ente que ele que reproduzir ao qual ele quer se igualar e, ao mesmo tempo, um conhecimento genuíno sobre ele. Como nos fala Gadamer:

\begin{abstract}
A imitação tem pois, como representação, uma função de conhecimento característica. O conceito da imitação pode, por esse motivo bastar para a teoria da arte, enquanto o significado de conhecimento da arte continuou indiscutível. Mas isso só será válido enquanto permanecer garantido que conhecimento do verdadeiro é conhecimento da essência, já que um tal conhecimento serve à arte de uma maneira convincente. (GADAMER, 1997, p.194)
\end{abstract}

Outro aspecto importante a ser observado é que Gadamer dá uma especial atenção em como se configura a encenação. A maneira como se constrói e se realiza o espetáculo teatral, a leitura de uma poesia, a interpretação musical, a brincadeira, um jogo de futebol, por exemplo, "não pode ser separada como algo que não pertence ao seu ser essencial" (ibid, p.195). Em outras palavras, na construção do cenário de um jogo está a própria essência daquilo que se apresenta. O jogo se converte imediatamente em construto (ou configuração), pois só há um jogo em uma determinada montagem. Assim, diante de um quadro, por exemplo, o cenário que nos é apresentado abre e delimita as possibilidades do jogo. Nesse sentido, não devemos acrescentar nada do que já não esteja ali e o jogo de perguntas e respostas deve se dar a partir do que se abre na própria relação com a obra $^{33}$.

A experiência da obra de arte é, portanto, uma experiência que educa, uma experiência formadora, uma experiência que pode nos ensinar a perguntar e a encontrar na própria coisa aquilo que ela nos permite dizer. A experiência que, para a hermenêutica, tem o sentindo de tornar-se transformado pela experiência, como veremos a seguir com a ideia de diálogo e de Bildung. No que diz respeito à formação, a hermenêutica filosófica de Gadamer não está interessada no acúmulo de informações (no saber que), mas sim naquilo que acontece conosco quando empreendemos uma busca por conhecimento.

\footnotetext{
${ }^{33}$ Essa ideia fica mais clara no ensaio Platão como Portraitista, escrito em 1988. Nesse texto, Gadamer mostra como os diálogos platônicos se configuram como verdadeiros retratos (portrait) feitos por Platão.
} 


\section{4. Perspectivas para uma educação hermenêutica: a emergência do diálogo na formação}

A partir do que vimos sobre o jogo podemos aqui pensar nas situações em que professor e aluno se encontram em uma relação formal de educação. Vimos que o diálogo não é simplesmente troca de falas, mas sim algo que ocorre como condição para o fato de haver indivíduos que conversam entre si. Diante de um espetáculo, aquele que o assiste poderá ser conduzido por essa experiência de tal maneira que sua própria identidade deixa de se fazer presente e o jogo se assenhora de todos que ali se encontram. Essa situação, contudo, é compreendida pela hermenêutica exatamente como uma situação de diálogo, e nela se estabelece um jogo de perguntas e respostas. Desse modo, podemos colocar aqui as seguintes questões: mesmo no caso de professor e aluno não realizarem uma interlocução em torno de um determinado assunto, ainda assim podemos dizer que existe entre eles um diálogo? Em outras palavras quando não há um debate acerca de algo, ou um questionamento de parte a parte, podemos pensar nessa relação como também uma relação de jogo de perguntas e respostas?

Para dar início a essa reflexão, é preciso lembrar que, para Gadamer, o diálogo tem fundamentalmente uma dimensão ontológica. Como vimos, o diálogo não é uma simples troca personalista entre sujeitos que dialogam. Antes mesmo que possa haver qualquer interlocução, o diálogo precisa já ter se estabelecido de alguma forma. O diálogo é a própria condição de surgimento dos interlocutores, no caso, professor e aluno. Isso significa dizer que quando professor e aluno aparecem um para o outro enquanto tais, isto se dá porque ambos se reconhecem na medida em que partilham de alguma questão, mesmo que na forma de uma disputa. Ser professor e ser aluno já surgem como identidades dialógicas, isto é um precisa aparecer para o outro enquanto tal. Dito de outra forma, em um nível ontológico, quando o diálogo se estabelece, já se deu uma fusão de horizontes compreensivos e é ela o que possibilita que algo como professor e aluno possa aparecer um para o outro em uma determinada circunstância. Ao assumirem uma postura monológica, professor e aluno recusam aquilo que é condição e limite de seu próprio autorreconhecimento.

Por conta disso, Gadamer também considera a existência do falso diálogo e das perguntas que não são verdadeiras. Em suma, um falso diálogo numa situação 
de ensino seria aquele em que o próprio caráter dialógico da experiência educativa se encontra alienado. $\mathrm{O}$ discurso do outro não aparece mais como algo de fato relevante em uma conversação. Professor e aluno, portanto, já não se orientam mais pela abertura que requisita a fala de ambos de um para o outro. Ambos realizam suas atividades de forma alienada e independente, sem estabelecerem de fato uma relação. Nesse contexto, também as perguntas não se orientam pela abertura que elas encontrariam na experiência com as coisas em questão. Como vimos anteriormente, o professor propõe uma pergunta e apenas espera por uma resposta que seja exatamente aquilo que ele já julga saber e que já está decidido de antemão. Essa situação em que se julga que nada é possível ensinar aos outros e nada é possível aprender deles repercute, então, em uma atitude monológica. O professor faz perguntas retóricas que ele mesmo responde. Nas palavras de Gadamer:

No comportamento dos homens entre si o que importa é, como já vimos, experimentar o tu realmente como um tu, isto é, não passar por alto sua pretensão e deixar-se falar algo por ele. A isso pertence a abertura. Mas, por fim, esta abertura não se dá para aquele por quem queremos nos deixar falar; antes, aquele que em geral se deixa dizer algo está aberto de maneira fundamental. Se não existe esta mútua abertura, também pouco existe verdadeiro vínculo humano. Pertencer-se uns aos outros quer dizer sempre e ao mesmo tempo poder-ouvir-se-uns-aos-outros. Quando dois se compreendem, isto não quer dizer que um "compreenda" o outro, isto é, que o olhe de cima para baixo. E igualmente, "escutar o outro" não significa simplesmente realizar às cegas o que o outro quer. Ao que é assim se chama submisso. A abertura para o outro implica, pois, o reconhecimento de que devo estar disposto a deixar valer em mim algo contra mim, ainda que não haja nenhum outro que vá fazer valer contra mim. (GADAMER, 1997, p.532)

Sem que exista a abertura de um para o outro, não há de fato um diálogo. Ambos não ouvem um ao outro e não perguntam e respondem de modo a fazer aparecer aquilo que está em questão. É interessante a ponderação de Gadamer sobre o fato de que escutar o outro não significa seguir cegamente o que o outro nos diz. Mesmo nas relações em que o outro não responde por si e deve, por isso, seguir as orientações de um responsável, dificilmente haverá uma simples obediência. Nesse ponto, parece que o tema da autoridade reaparece. Como vimos no início desse estudo, Gadamer entende que a autoridade não deve ser confundida com uma simples imposição pelo uso da força. "A autoridade das pessoas não tem seu fundamento último num ato de submissão e de abdicação da razão, mas num ato de reconhecimento e de conhecimento" (GADAMER, 1997, 
p.419). Autoridade tem a ver com o possível reconhecimento de que o outro possui mais conhecimento sobre algo e que, por isso, seu juízo pode ser mais acertado que o nosso próprio juízo. Dessa forma, ouvimos o que o outro nos diz e nele confiamos. A abertura do aluno para o que diz o professor também passa pelo reconhecimento da autoridade nesse sentido apontado por Gadamer.

Entretanto, não podemos perder de vista que Gadamer também defende na já citada conferência dada nos seus últimos anos de vida que educação é educarse. A educação é um movimento em que o sujeito, a partir do diálogo com o outro, coloca seus preconceitos e conhecimentos prévios em jogo e com isso os transforma, os amplia, ou os substitui. Para a hermenêutica gadameriana, é assim que a educação acontece. $O$ professor não transpõe para o aluno aquilo que ele mesmo já conhece. Dessa maneira, o que o professor pode fazer é criar as condições para que o aprendizado aconteça. Mais do que educar e ensinar o outro, o professor leva o aluno a educar-se (educar a si próprio) e a aprender por si mesmo, através de suas próprias questões. Mas como exatamente ele pode fazer isso?

A afirmação de Gadamer, de que "a educação é educar-se" (2000), nos leva a pensar a experiência educativa como algo que não se pode impor ao outro e que a pretensão de objetificar o aluno através de um processo de ensino não encontra nenhum amparo no modo próprio de ser da educação. Na educação, tudo aquilo que o aluno efetivamente aprende necessita entrar em conflito com suas précompreensões, que assim passam por um processo de possibilidade de transformação. Essa possibilidade de transformação é o que compreendemos como sendo a própria educação. Este é, contudo, um processo cujos resultados, não podemos prever antecipadamente e que só é possível de se realizar através do diálogo, ou seja, desse jogo de perguntas e respostas que se estabelece entre os que se colocam em cena nas situações de ensino e aprendizagem.

O diálogo, por sua força vinculante, é o que nos requisita a todo o momento a elaboração e reelaboração de sentido, no esforço de compreendermos e de nos tornarmos compreensíveis aos outros. Evidentemente, naquele modelo de educação em que o espaço para o diálogo é restringido, as possibilidades para a aprendizagem também são menores.

Em outras palavras, ao reconhecer que é através do diálogo que o homem educa a si mesmo com o outro, Gadamer evidencia que todo o processo 
pedagógico está fundado no diálogo. Mesmo quando não temos uma efetiva dimensão disso. Portanto, uma transformação efetiva da escola passa, necessariamente, por compreendermos essa relação e abrirmos espaço para que esse diálogo aconteça. Dar a palavra a quem aprende e efetivamente ouvi-lo, para que ele possa experimentar os limites daquilo que ele conhece e buscar a sua ampliação.

Evidentemente, a formação não se restringe às experiências pelas quais o indivíduo passa no ambiente escolar. Contudo, compreendemos que os ambientes formais de educação têm a singularidade de oferecer conteúdos específicos e estabelecer alguns objetivos e metas a serem alcançadas. Existe sobre essa dimensão da formação - a formação escolar - uma expectativa de que todos saiam conhecedores de um determinado conjunto de coisas. Muitas vezes, as dificuldades que os alunos apresentam em adquirir esses conhecimentos é o que faz com que a educação se volte para si mesma e se pergunte onde se encontra o problema. Por que esses alunos não estão aprendendo? Essa indisponibilidade para o aprendizado, contudo, se mostra bastante específica em muitos casos: o aluno demonstra dificuldade de aprender aquilo que a escola ensina. Não somente os conteúdos curriculares de determinadas disciplinas que compõem a forma escolarizada do conhecimento, mas também algumas habilidades que a escola pressupõe que são necessárias para que os alunos entrem em contato com esse conteúdo. Essas habilidades vão desde a capacidade de concentração e disciplina até a habilidade de se expressar através da escrita e oralmente. Para a hermenêutica, esse conhecimento tem um caráter bastante específico dentro da Bildung (que seria um conceito de formação mais amplo). Nesse sentido, cabe aqui nos debruçarmos num detalhamento das características mais amplas do conceito de Bildung desenvolvido por Gadamer. Como avalia Davey:

Gadamer evoca o termo Bildung por um objetivo estratégico: demonstrar que ao lado do conhecimento científico e técnico existe outro corpo de conhecimento que não é resultado de provas e demonstração, mas está colocado pela tradição, recebeu a sabedoria e a experiência da prática. (DAVEY, 2006, p.30)

Ao chegar à escola, por mais que o aluno desconheça os princípios pelos quais algo como o dia e a noite se dão e, também, as sucessões da estação do ano, ele já experimenta compreensivamente esses fenômenos. Esse conhecimento prévio que o aluno traz, já se encontra permeado de algumas justificativas, que ele 
aprende dentro das suas relações familiares mais próximas, juntamente com outros valores e crenças. Estas justificativas podem ser mais ou menos adequadas às já conhecidas pelas ciências. É possível dizer, por isso, que esse saber não se encontra somente ao lado, mas também subjaz o próprio conhecimento científico, uma vez que é a partir deste saber que ele poderá elaborar novas questões e, com isso, avançar em direção a outros conhecimentos mais formais e amplamente aceitos sobre os mesmos fenômenos.

A hermenêutica gadameriana compreende a formação do indivíduo como sendo constituída de dimensões da Bildung. O termo, em alemão, compreende variados significados e pode ser empregado como formação, cultura e educação. Gadamer o descreve da seguinte maneira:

Da mesma forma, o triunfo da palavra formação sobre forma não parece só acaso. Porque em "formação" (Bildung) encontra-se a palavra "imagem" (Bild). O conceito da forma fica recolhido por trás da misteriosa duplicidade com a qual a palavra "imagem" (Bild) abrange ao mesmo tempo "cópia" (Nachbild) e "modelo" (Vorbild). (GADAMER, 1997, p.50)

Assim, sobre aquilo que geralmente é esperado pela escola, vemos que por exemplo, escrever e ler não é simplesmente desenvolver uma habilidade. Ter aprendido a escrever e ler é ter entrado em contato com certa quantidade de conhecimentos que foram acumulados e transformados ao longo de muitos e muitos séculos na humanidade. Quando um indivíduo, na sua formação, aprende a escrever, ele o faz em conformação com um modelo de escrita já vigente em sua cultura. Ele assim, se forma em acordo com uma forma, um modelo. $\mathrm{O}$ fato de ele ter adquirido essa habilidade não significa que não se faz necessário evocar as regras de escrita. Na verdade, essa aquisição significa que o indivíduo já as tornou suas de tal modo que a elas recorre como um conhecimento já adquirido. Segurar o lápis, escrever da esquerda para a direita, de cima para baixo são conhecimentos que o indivíduo adquire, ou seja, não são habilidades que ele desenvolve simplesmente. Para Davey, "ter alcançado uma compreensão de certo assunto implica que um certo corpo de conhecimento foi adquirido" (2006, p.31). Do mesmo modo, Gadamer nos fala que:

Na formação, (...) no que e através do que alguém será instruído, pode também ser inteiramente assimilado. Nesse sentido, tudo que ela assimila, nela desabrocha. Mas na formação aquilo que foi assimilado não é como um meio que perdeu sua função. Antes, nada desaparece na formação adquirida, mas tudo é preservado. A 
formação é um conceito genuinamente histórico, e é justamente o caráter histórico da "preservação" o que importa para a compreensão das ciências do espírito. (GADAMER, 1997, p.50)

Ao chegar à escola, algumas crianças já demonstrarão mais ou menos domínio sobre as habilidades que serão desenvolvidas formalmente. Isso porque elas podem ou não trazer, de seu ambiente familiar, a compreensão dessas práticas. Aqui novamente vemos que será no diálogo que seus conhecimentos prévios se revelarão. Na tentativa de realizar o que a escola propõe, o aluno coloca em jogo aquilo que previamente compreende sobre determinado assunto. Quando a escola não considera a existência desses conhecimentos prévios e não realiza um movimento em direção ao aluno buscando mobilizá-los, o campo para que esse diálogo se realize se encontrará bloqueado.

Somente no diálogo, aquele que aprende poderá compreender os limites do próprio horizonte e perceber que, para além daquilo que ele domina compreensivamente, existe muito mais a ser compreendido. E que aquilo que ele compreende na tradição em que se encontra, encontra-se, por sua vez, em meio a outros conhecimentos e outras possibilidades compreensivas. $\mathrm{O}$ horizonte compreensivo pode ser expandido justamente quando ele se funde com outros horizontes se consegue revelar a finitude de um posicionamento inicial. Essa busca tem o indivíduo que aprende como protagonista, como aquele que educa-se em diálogo com o outro:

É completamente claro que determinadas unidades do planejamento devem ser respeitadas, mas o decisivo é, contudo, que finalmente se dê ao adolescente a capacidade de suprir suas próprias lacunas de saber através de sua própria atividade. $\mathrm{O}$ educar-se deve consistir antes de tudo em potencializar suas forças lá onde você percebe seus pontos fracos e em não deixar nas mãos da escola ou muito menos, confiar às qualificações que constam nos certificados aquilo que, talvez, os pais compensariam. (GADAMER, 2000, p.40)

Dentro disso, é importante entender que a Bildung hermenêutica, como bem sinaliza Davey, tem um interesse especial não apenas naquilo que se sabe sobre algo, o "saber que", mas naquilo que ocorre com o indivíduo no processo de aquisição desses saberes. Para a hermenêutica, "apenas se expondo às experiências a que se está exposto na aquisição prática de fatos e habilidades pertinentes a uma dada disciplina, é possível se tornar um bom, ou então, mais compreensivo, praticante" (DAVEY, 2006, p.31). Mais uma vez, como no 
exemplo anteriormente utilizado, aquele que compreende as regras da língua escrita, lança mão delas sem que precise fazê-lo reflexivamente a cada vez que escreve. É como se aquele corpo de conhecimento já estivesse incorporado por sua compreensão, tal como a própria habilidade de pensar e falar. Aquele que se tornou experiente na escrita, não apenas tem um conhecimento sobre algo, mas transformou-se de tal modo na aquisição desse conhecimento que já não é possível separar essa habilidade daquilo que ele mesmo é de maneira mais vital. Assim, Davey analisa que:

Um significado de Bildung é cultura. Bildung haben pode significar ser ou tornarse culto. Ser culto supõe uma familiaridade com os estoques de conhecimentos e atitudes que constituem uma determinada cultura. No entanto, a familiaridade com esse conhecimento por si só não é capaz de permitir que uma pessoa se torne culta. Mais uma vez, é o processo de tornar-se intelectualmente e espiritualmente, temperados pelas experiências que se sofre durante a aquisição desse conhecimento, o que importa. Na medida em que atesta o transformador processo educativo através do compromisso e envolvimento, a hermenêutica filosófica incorpora uma defesa desafiadora da tradição humanista. (DAVEY, 2006, p. 32)

A experiência hermenêutica de formação tem $o$ caráter de um enriquecimento compreensivo. Neste enriquecimento compreensivo o homem se torna formado - gebildet, através da aquisição de experiência por conhecimento. Ter-se tornado gebildet é ter-se tornado mais rico de experiências hermenêuticas. O que caracteriza uma pessoa experiente é possuir algumas virtudes, como por exemplo, "uma flexibilidade de respostas para o estranho e o inesperado" (idem). A pessoa experiente é a que percebe a excepcionalidade de novas situações mais rapidamente e, ainda assim, consegue buscar respostas adequadas a estas. Por outro lado, a pessoa ungebildet, ou inculta, deixa-se levar pelo particular e com frequência não consegue encontrar por si só uma boa medida para as suas ações.

Para Gadamer, a filosofia de Hegel nos fornece uma visão bastante nítida sobre o que venha a ser tornar-se gebildet. Também teria sido Hegel "que viu que a filosofia "tem na formação, a condição de sua existência'" (GADAMER, 1997, p.51). Gadamer considera que o mesmo ocorre com as ciências do espírito, ou seja, que "o ser do espírito está vinculado essencialmente com a ideia de formação" (idem). Isso porque "o homem é assinalado pela ruptura com o imediato e o natural, o que lhe é exigido através do lado espiritual e racional de sua natureza" (idem). Assim, ele não é o que seria por natureza, ele é o que a formação o torna. Essa formação repousa em uma universalidade à qual o homem 
se eleva dentro de sua própria época, ou seja, de seu próprio horizonte histórico. Segundo Gadamer:

Elevação à universalidade não é, p. ex., ver-se restringido pela formação teórica e não significa, de forma alguma, apenas um comportamento teórico em oposição a um prático, mas cobre o todo da determinação da essência da racionalidade humana. É da essência universal da formação humana tornar-se um ser espiritual, no sentido universal. Quem se entrega à particularidade é inculto (ungebildet), $\mathrm{p}$. ex., quem cede a uma ira cega, sem medida nem postura. Hegel demonstra que, no fundo, numa tal pessoa está faltando poder de abstração: não consegue deixar de se levar em consideração e ter em vista um sentido universal, pelo qual paute sua particularidade com medida e postura. (GADAMER, 1997, p.51)

Aqui podemos perceber uma familiaridade com a ideia de horizonte como descrita pelo próprio Gadamer. Aquele que supervaloriza o que está mais próximo tem um campo de visão muito curto. Por outro lado, quanto maior é o campo de visão, mais rico de possibilidades ele é. Essa amplitude de horizontes só é possível na formação, uma vez que é ela que aproxima aquilo que é desconhecido e o torna conhecido, transformando assim toda a compreensão. No processo de tornar-se gebildet, o indivíduo se torna mais habilidoso diante de novas situações, uma vez que ele tem mais possibilidades de respostas a elas.

Muito embora o termo Bildung precise ser esclarecido em suas equivocidades, o fato de o conceito de Bildung ser amplo e equívoco deve ser considerado em seu aspecto positivo. Davey também sugere que exista um paralelo entre Bildung e fusão de horizontes - Bildung seria uma co-fusão, ou seja, uma fusão ou um entrelaçamento de determinação mútua entre diversos elementos. Como observa Davey, "embora a hermenêutica filosófica não seja um sistema filosófico, os diferentes elementos que estão dentro de seu raciocínio se encontram sistematicamente conectados" (2006, p.33).

Aqui, não podemos perder de vista que a Bildung é um processo que não se finaliza. Ainda que seja possível reconhecer algumas acumulações que se consolidam na formação: como a própria língua falada e demais elementos da cultura na qual o indivíduo se forma, por ser um processo formativo e transformativo (dialógico), ele é um processo que nunca se completa totalmente. Podemos dizer, que a formação se dá na mesma dinâmica do encontro hermenêutico, como bem coloca Davey:

Na medida em que as partes envolvidas no encontro hermenêutico emergem do seu pensar diferenciado sobre elas mesmas, Bildung é transformativo. Bildung é, em 
parte, o processo de começar a entender o que nós temos entendido de modo diferente. Bildung é formativo quando traz algo a ser a partir do encontro. Isto forma a civilidade hermenêutica entre aquele que é submetido a todos os outros para tornar-se diferente para ele mesmo, e quem sabe que eles são dependentes uns dos outros abrindo potencialidades de entendimento de que não estavam presentes. (DAVEY, 2006, p33)

É possível pensar, a partir dessa potencialidade transformativa da formação, no fato de que com frequência a formação escolar é acusada de não dialogar com aquilo que os alunos experimentam em seus contextos de vida e de não ouvir aquilo que os alunos já trazem de experiência, e que esse encontro entre os que estão presentes no ambiente escolar, muitas vezes não resulta em um entendimento ou pelo menos, em uma abertura de um para o outro. O que é possível de se pensar, a partir da ideia de Bildung, é que só há uma efetiva transformação dos preconceitos e uma ampliação do conhecimento quando existe diálogo, na medida em que há um pôr-se em questão. A educação escolar, então, não é capaz de propiciar essa transformação quando ela não é capaz de promover a abertura para o diálogo. Por vezes, torna-se claro que os conteúdos escolares não interferem na dimensão ética das relações, como se estes conhecimentos fossem de fato apenas uma moeda de troca na educação bancária descrita por Paulo Freire $^{34}$. Os diversos "saberes que" memorizados pelos alunos ganham o caráter de conteúdos depositados pelo professor, e que mais adiante são cobrados nas avaliações em troca da certificação. Podemos levantar aqui a hipótese de que um dos fatores que tenha levado a esse distanciamento entre os conteúdos e a dimensão prática da vida tenha sido a própria tentativa de se buscar uma universalidade para o conhecimento, ou seja, a tentativa de afastar o conhecimento científico do relativismo ao mesmo tempo em que se buscava uma neutralidade. Em resposta a essa questão, Davey nos diz que:

\footnotetext{
A hermenêutica filosófica argumenta que rejeitar os apelos de uma compreensão histórica e estética em nome de um modo abstrato de conhecimento despojado da influência da tradição e da subjetividade, é agir (talvez inconscientemente) em nome do niilismo. Como temos argumentado, a hermenêutica filosófica não busca remover a subjetividade da compreensão, mas tornar-se consciente das objetividades presentes dentro dela. Como são as formações culturais e os padrões de interpretação que constituem tais objetividades, é adequado que a Bildung deva ter um lugar de destaque na reflexão da hermenêutica filosófica. (DAVEY, 2006, p.41)
}

\footnotetext{
${ }^{34}$ FREIRE, Paulo. Pedagogia do Oprimido. Rio de Janeiro: Paz e Terra, 2014
} 
Assim, não se trata de uma completa formação, ou seja de uma Bildung, quando não está clara a dimensão ética do conhecimento a partir do qual se forma. Nesse sentido a escola só pode de fato ser um ambiente que promova uma transformação, quando ela é capaz de reconhecer "objetividades" dentro das "subjetividades". Muito embora objetividade e subjetividade sejam conceitos controversos, podemos concedê-los aqui sob uma perspectiva hermenêutica. Reconhecemos que cada indivíduo se forma de um modo sempre singular, contudo, ele sempre o faz a partir de um horizonte histórico da tradição. Essa singularidade, portanto, continua sempre a revelar novos elementos desse horizonte partilhado, no qual ele se formou, isto é, desse construto, desse cenário onde ele joga. Esses elementos são, em certa medida, reelaborados na apropriação individual, na participação no jogo, porém, eles preservam em sua essência, aquilo que é compartilhado pelos indivíduos que se encontram nessa mesma tradição.

Gadamer considera que em uma tradição existem aqueles preconceitos, "cuja superação representa a inquestionável tarefa de toda razão crítica" (GADAMER, 1997, p.416). As questões que se colocam acerca disso são, por exemplo: “em que pode basear-se a legitimidade de preconceitos?" (idem) Em que medida eles se diferenciam uns dos outros? Ora, diante do que apresentamos nesse estudo, percebemos que aquilo que os diferencia pode se revelar em um maior grau de evidência com a distância temporal e com o conhecimento da história e de seus efeitos. Contudo, ainda assim, não podemos ignorar que, mesmo aqueles preconceitos que reiteradamente já foram colocados em suspenso, não desaparecem simplesmente de uma tradição. Nesse caminho, a escola é chamada a formar a tal "razão crítica" da qual fala Gadamer, na esteira da tradição filosófica, além disso, a tarefa dessa razão hermenêutica nunca pode se realizar por completo. Por vezes, ela é compreendida como mais uma coisa a ser trabalhada pela escola, para além de todas as atribuições que ela já tem. Contudo, esta parece ser uma maneira equivocada de compreender a relação entre formação e conhecimento. A formação de uma razão crítica não deve se colocar ao lado de todo conhecimento, mas sim como condição da própria formação. A capacidade de manter-se aberto ao que o outro nos diz e de, a cada vez, se colocar em questão a partir disso, é o que se espera de uma pessoa que conseguiu tomar para si a tarefa de sua formação: 
Também é importante lembrar que Bildung e tornar-se gebildet é uma prática, é a formação da capacidade, da habilidade de se manter aberto para o que é o outro no outro para ganhar a noção sobre si mesmo. Bildung, portanto, tem uma clara dimensão ética. (DAVEY, 2006, p.41)

O que fica claro a partir do que vemos é que todo conhecimento tem suas implicações éticas na formação do indivíduo e que isso só se revela quando não encobrimos sua dimensão histórica. Em outras palavras, a educação precisa se manter aberta para pôr em questão quais são as implicações éticas daquilo que ela compreende como conhecimento. Ela também não deve perder de vista o que aquilo que o seu currículo compreende traz de questões para aqueles que nele se formam. Somente uma educação que se configure como o exercício dessa abertura seria capaz de formar tal razão. 


\section{Conclusão}

O combate aos preconceitos tem se mostrado como um dos grandes desafios colocados em nossa sociedade. A busca pela igualdade entre todos os indivíduos e, ao mesmo tempo, o reconhecimento de suas diferenças é uma luta incessante. A escola, então, é convidada a se engajar nessa luta, justamente por ser vista como o lugar que pode servir tanto à reprodução de preconceitos, quanto a superação dos mesmos. Essa exigência de que a escola se posicione não se dá por acaso: ela se dá exatamente quando alcançamos a percepção de que a escola não tem conseguido promover de forma satisfatória a formação de uma grande parcela de indivíduos que passaram a frequentá-la com as políticas de democratização do ensino.

Para além da dificuldade em atender aqueles que mais facilmente eram excluídos dos sistemas de ensino - o que ficou ainda mais evidente no contexto de democratização do acesso - existe a ideia de que a educação, num sentido mais amplo, encontra-se em crise e que, por isso, as instituições de ensino precisam rever os paradigmas que as têm sustentado. Vemos, contudo, que as necessidades cotidianas que envolvem manter o fluxo contínuo de um grande e diversificado grupo de alunos faz com que, em muitos casos, a escola se distancie de reflexões mais profundas acerca de sua própria tarefa de educar. Esse distanciamento, contudo, tem reflexos no modo como ela lida com todo e qualquer conhecimento. Assim, a tarefa de combater preconceitos, acaba por entrar no bojo de suas atribuições sem que nem mesmo haja um aprofundamento acerca do que significa, afinal, assumir essa tarefa. O que reforça, sobretudo, a necessidade de uma formação teórica contínua de todos que atuam na educação. Como nos fala Gadamer, "o bom funcionamento não pode ser tomado como um valor em si”. O fato de a escola estar seguindo bem seus protocolos pode inclusive encobrir muitos de seus problemas. Nesse cenário, é notório que as instituições de ensino que reconhecem, incentivam e conseguem garantir o espaço de formação de seus professores e funcionários têm conseguido importantes avanços em promoverem uma educação que se mantém se aberta a refletir acerca de seu sentido.

Entendemos que diante de um contexto de profundas transformações, faz-se necessário voltar ao questionamento sobre como temos compreendido alguns 
conceitos. Desse modo, cabe então o esclarecimento conceitual acerca do que é, afinal, o preconceito. Com o objetivo de debater essa questão, o presente trabalho teve como tema norteador as contribuições que a hermenêutica de Gadamer pode oferecer para pensarmos sobre como atuam os preconceitos nos processos de formação, sobretudo no contexto escolar. Acreditamos que o modo como o filósofo apresenta a formação do horizonte compreensivo dos indivíduos e sua possibilidade de expansão e transformação através do diálogo representa uma virada na forma como temos entendido o significado dos preconceitos desde a Aufklärung. Entendemos que esse debate pode ampliar a visão de educação escolar iluminista, pela qual temos nos guiado fundamentalmente, que crê que o problema dos preconceitos é unicamente o preconceito entendido como uma forma negativa de discriminação.

Para dar início ao nosso estudo, fizemos um levantamento bibliográfico do autor, além de uma contextualização e apresentação de sua principal obra: Verdade e Método I. Vimos que sua obra é escrita em diálogo com os pensadores com quem Gadamer conviveu durante sua vida e também dos quais se aproximou através de seus estudos. Após essa breve apresentação, que compõe a introdução deste trabalho, dividimos nossos estudos em duas seções. Na primeira, nos dedicamos ao estudo dos conceitos que fundamentam a filosofia de Gadamer. Embora nossa intenção fosse tratar do preconceito e do diálogo, vimos que não seria possível abordar esses temas sem que houvesse também um aprofundamento naquilo que Gadamer pensou acerca de questões como a compreensão, a tradição, a autoridade e a distância temporal, por exemplo. Isso porque, mesmo que a hermenêutica de Gadamer não se compreenda como um sistema filosófico, como ressalta Davey, "os diferentes elementos que estão dentro de seu raciocínio se encontram sistematicamente conectados" (2006, p.33). Sendo assim, impossível pensar preconceito e diálogo isoladamente.

Apresentamos, então, num primeiro momento, como Gadamer chega à ideia de que os preconceitos são constitutivos da compreensão enquanto modo de ser do ser humano. Com isso, chegamos à questão que passou a guiar todo o nosso estudo. Uma vez que Gadamer considera que nossa compreensão se constitui fundamentalmente dos preconceitos herdados de nossa tradição, como a educação seria capaz de formar essa "razão crítica", a qual se refere o filósofo, capaz de superar inumeráveis preconceitos ilegítimos? 
Considerar "o preconceito contra o preconceito" como um problema cultivado pelo pensamento moderno, não significa, de modo algum, fazer uma apologia do preconceito, ou mesmo admitir que os indivíduos não possam ser responsabilizados pelos preconceitos herdados de sua tradição. Bem diferente disso, Gadamer nos auxilia a justamente colocar novamente à luz o horizonte histórico da formação de tais preconceitos dentro de uma tradição. O que pode nos dar mais elementos na busca pelos meios de confrontar aqueles preconceitos que já se mostraram ilegítimos, mas que ainda permanecem orientando muitas de nossas concepções e práticas.

Em seguida, apresentamos como Gadamer caracteriza o conceito de diálogo e como nossos preconceitos se manifestam durante sua realização do diálogo. Vimos que, para Gadamer, estarmos vinculados à coisa sobre a qual nos referimos no diálogo revela o nosso pertencimento a um horizonte comum mais amplo, que nos garante uma comunidade de preconceitos fundamentais. Esses preconceitos, que compartilhamos uns com os outros, nos fornece uma compreensão formada com relação às coisas, o que, na maioria das vezes, não é fruto de um questionamento explícito. No diálogo, no entanto, percebemos a existência de uma tensão entre familiaridade e estranheza com relação ao que nos diz o outro. Isso nos leva a concluir que esse horizonte, no qual se funda a nossa tradição, não é uma unidade inquestionável e autoevidente de sentido. No diálogo verdadeiro, quando existe a real abertura para o que nos diz o outro, colocamos em jogo nossos preconceitos e experimentamos a ampliação dos limites de nossa própria compreensão.

Terminamos essa primeira parte com uma leitura gadameriana da Alegoria da Caverna de Platão. Consideramos interessante apresentar essa leitura justamente por que ela subverte uma visão mais comum da relação pedagógica e nos leva a pensar essa relação como uma fusão ao invés de uma transição de um "não saber" para um "saber”. Para Gadamer, existe uma ignorância inerente ao saber, uma vez que aquilo que sabemos não é algo acabado. Assim, não existe um acúmulo de conhecimentos e um progresso na superação de preconceitos. O que há, ou deve haver, é um exercício de manter-se aberto a colocar em jogo tudo o que já era conhecido a cada vez.

Iniciamos a segunda parte do trabalho voltando ao contexto em que se insere a questão que guiou nossos estudos, que é o contexto da experiência 
educacional. Problematizamos duas tendências que se polarizam dentro dos debates no campo da educação. Essas tendências são mais facilmente identificáveis quando existe uma radicalização dos discursos e quando os argumentos são levados às suas últimas consequências. Desse modo, buscamos localizar onde melhor caberiam as contribuições trazidas pela hermenêutica de Gadamer. Concluímos que Gadamer melhor se insere ao lado daqueles que se propõem a repensar a educação, sem renunciar à sua legitimidade institucional. As contribuições de Gadamer se dão no sentido de colocar luz sobre concepções, como a de indivíduo, racionalidade, tradição, autoridade e diálogo, que parecem ter reaberto suas possibilidades interpretativas no momento atual. Essa nossa percepção parece se confirmar logo adiante, quando vemos que Gadamer adota, no campo político, uma postura conciliadora das diferenças, ao mesmo tempo em que preserva sua tensão sem almejar equalizá-las.

Ao longo do nosso trabalho construímos o entendimento de que educação de caráter hermenêutico seria aquela capaz de promove um autoquestionamento e uma autocompreensão que rompa com os dogmatismos que impedem que o indivíduo cultive a abertura que o seu constante processo de formação requisita. Algo que necessariamente requisita o diálogo com o outro, uma vez que somente na tensão entre o conhecido e aquilo que nos interpela como diferente que é nossos preconceitos se mobilizam e se transformam.

Esse cultivo da abertura é algo que também se mostra necessário para que a experiência estética se realize. A experiência estética, para a hermenêutica de Gadamer, não é operada por uma subjetividade, nem, tão pouco, simplesmente imposta pelo objeto artístico. Ela se funda na relação entre o indivíduo que interpreta e o ser do interpretado. Na interpretação de uma obra, também existe um diálogo, ou uma fusão de horizontes, capaz de revelar algo não só da obra, mas também de quem a interpreta. Desse modo, a experiência estética pode culminar numa autocompreensão e um autoquestionamento.

Vimos que o modo como a hermenêutica compreende a experiência estética nos permite encontrar em tal experiência, sua dimensão ética, uma vez que o diálogo com a obra de arte revela-se como um encontro com questões relativas à nossas crenças, valores e modo de agir, ou seja, com nosso ser ético. A experiência estética, por isso, também revela seu caráter pedagógico, uma vez que educação para Gadamer é algo que o indivíduo realiza sobre si em diálogo com o 
outro. Na experiência estética, o outro que mobiliza nossas orientações prévias de mundo é a obra de arte. Contudo, como bem observa Hermann, "Não se trata também de uma experiência que ensina isto ou aquilo, mas da experiência que incide sobre nosso inacabamento". (2010, p.116). Esse inacabamento significa algo positivo, no sentido de que ainda estamos nos transformando pelas experiências, que ainda somos tocados e mobilizados por elas.

A experiência da obra de arte é, portanto, uma experiência que educa, pois revela, muitas vezes, a insuficiência do que sabermos. Nesse encontro com a experiência estética, vimos que aquilo que nos diz a obra de arte só se revela no jogo de perguntas e respostas. Elaborar as perguntas adequadas é uma tarefa que exige também alguma compreensão prévia acerca do que é perguntado. Existe um horizonte ao qual a pergunta se vincula e pelo qual ela se orienta, em outras palavras, quanto mais amplo o horizonte do indivíduo, maior será suas possibilidades interpretativas.

Por fim, vimos que no que diz respeito à formação, a hermenêutica filosófica de Gadamer não está interessada no acúmulo de informações (no saber que), mas sim naquilo que acontece conosco quando empreendemos uma busca por conhecimento. Para Gadamer, esse é o sentido de uma formação compreendida como Bildung.

Acreditamos que é exatamente essa a contribuição que Gadamer pode oferecer para a educação e esse é um tema que merece ainda ser explorado por todos aqueles que buscam transformar a escola em um local que promova um amplo encontro das diferenças e que permita a ampliação dos horizontes compreensivos daqueles que nela se encontram. Somente assim será possível forma a tal razão crítica, capaz de superar preconceitos que limitam a compreensão. 


\section{Referências Bibliográficas}

AZEVEDO, Janete Maria Lins. A Educação como Política Pública. 3. ed. Campinas: Autores Associados, 2008.

BENJAMIN, Walter. Obras Escolhidas - Magia e Técnica, Arte e Política. São Paulo: Brasiliense, 1994.

BICCA, Luiz. Racionalidade Moderna e Subjetividade. São Paulo: Edições Loyola, 1997.

.Luiz. A unidade entre ética, polítca e história na filosofia prática de Kant. Porto Alegre: L\&PM, 1987.

BRAIDA, Celso R.. Aspectos semânticos da hermenêutica de Schleiermacher. In: Róbson R. dos Reis; Ronai P. da Rocha. (Org.). Filosofia hermenêutica. Santa Maria: Ed. UFSM, 2000, v., p. 23-38.

BRASIL. Leis, Decretos. Constituição da República Federativa do Brasil - 1988. Brasília, 2006. Disponível em: < http://www.senado.gov.br/sf/legislacao/const/con1988

/CON1988_30.06.2004/CON1988.pdf > Acesso: 11 fev. 2020.

Disponível

Lei de Diretrizes e Bases da Educação Nacional - 1996.

$<\mathrm{ftp}$ //ftp.fnde.gov.br/web/siope_web/lei_n9394_20121996.pdf> Acesso:

11 fev. 2020.

BRIGHENTI, J; BIAVATTI, V. e SOUZA, T. Metodologias de ensinoaprendizagem: uma abordagem sob a percepção dos alunos. Revista GUAL, Florianópolis, v. 8, n. 3, p. 281-304, set. 2015.

BRITTO, Fabiano de L. Identidade Cultural e Formação Individual: a Alemanha do século XIX e a Fundação da pedagogia mederna. Educação \& Sociedade, Campinas, v. 33, n. 118, p. 217-233, jan.-mar. 2012.

Carta das Cidades Educadoras. Gênova. Disponível em: http://www.edcities.org/rede-portuguesa/wpcontent/uploads/sites/12/2018/09/Carta-das-cidades-educadoras.pdf Acesso em: 02 de março de 2020.

CANÁRIO, Rui. A escola tem futuro?: das promessas às incertezas. Porto Alegre : Artmed, 2006. 
CANDAU, Vera Maria. Educação Intercultural e Práticas Pedagógicas. In: Relatório Parcial da Pesquisa Direitos Humanos, Educação, Interculturalidade: construindo práticas pedagógicas, set de 2013.

CAYGILL, Howard. Dicionário Kant. Tradução de Álvaro Cabral. Rio de Janeiro: Jorge Zahar, 2000.

CHARLOT, Bernard. Da relação com o saber às práticas educativas. São Paulo: Cortez, 2013.

CUNHA L. A. O Desenvolvimento Meandroso da Educação Brasileira: entre o estado e o mercado. Educação \& Sociedade, out 2007, v.28, n. 100, p.809-829.

CURY, C. R. J.. O Público e o Privado na Educação Brasileira: posições e tendências. Cadernos de Pesquisa. São Paulo, Fundação Carlos Chagas, n. 81, p. 33-43, 1992.

DAVEY, Nicholas. Unquiet understanding: Gadamer's philosophical hermeneutics. Albany, NY: SUNY, 2006.

DAVIS, N. O Público, o Privado e o Estatal no Pensamento Educacional Brasileiro. Revista da Faculdade de Educação da UFF, n.8, 2003.

DI CESARE, Donatella. Gadamer: a Filosophical portrait. English translation by Insiana University Press, Bollmington, Indiana, 2013.

ESTEBAN, Maria Teresa. Avaliação e fracasso escolar: questões para debate sobre a democratização da escola. Rev. Lusófona de Educação n.13 p.123-134, 2009.

FERREIRA, Adriana M. R. Gil. Hermenêutica e educação: aproximações. Rio de Janeiro. Dissertação de Mestrado. Departamento de Educação. 127, 2011.Pontifícia Universidade Católica do Rio de Janeiro.

FREIRE, Paulo. Pedagogia do Oprimido. Rio de Janeiro: Paz e Terra, 2014.

GADAMER, Hans-Georg. A Idéia do Bem Entre Platão e Aristóteles. Tradução de Tito Lívio Cruz Romão. São Paulo: Editora WMF Martins Fontes, 2009.

. Hermenêutica em retrospectiva: Heidegger em retrospectiva. 1. ed. Tradução de Marco Antônio Casanova. Petrópolis: Vozes, 2007.

. Verdade e Método II. Tradução de Enio Paulo Giachini. 2. ed. Petrópolis: Vozes, 2002. 
. Elogio da Teoria. Tradução de João Tiago Proença. Lisboa: Portugal. Edições 70, 2001.

La Educación es Educarse. Tradução de Francesc Pereña Blasi. Barcelona: Paidós, 2000.

. Verdade e Método I. Tradução de Flávio Paulo Meurer. 3. ed. Petrópolis: Vozes, 1997.

GIL-FERREIRA. P.C. Golpismo e conservação: conflito de identidades ou identidade como conflito, in Sobre o Conceito de Golpe, Congresso, UFRJ, Rio de Janeiro, 06 de julho de 2016.

Realidade à Verdade: a critica de Martin Heidegger à fundamentação metafísica da verdade proposicional. Rio de Janeiro. Dissertação de Mestrado (Departamento de Filosofia) 2009. 217p. Universidade do Estado do Rio de Janeiro.

GRONDIN, Jean. (org.) O Pensamento de Gadamer. Tradução de Enio Paulo Giachini. - São Paulo: Paulus, 2012.

HEIDEGGER, Martin. Ser e Tempo I. Tradução de Márcia de Sá Cavalcante. Petrópolis: Vozes, 2001.

HERMANN, Nadja. Autocriação e horizonte comum: ensaios sobre educação ético-estética. ljuí : Ed. Unijuí, 2010.

Ética e Estética: a relação quase esquecida. Porto alegre: EDIPUCRJ, 2005.

Hermenêutica e Educação. Rio de Janeiro: DP\&A, 2002.

KANT et al. O que é Esclarecimento?; tradução Paulo Cesar Gil Ferreira; revisão Marco Antonio Casanova. - 1, Ed. - Rio de Janeiro: via Verita, 2011.

KANT, Immanuel. Sobre a Pedagogia. Tradução de Francisco Fontanella. $5^{\text {a }}$ ed. Piracicaba: Editora UNIMED, 2006.

Crítica da Razão Pura. In: KANT, Immanuel. Os Pensadores. São Paulo: Abril S.A. 1980.

Crítica da Razão Prática. Fonte Digital/ Digitalização da edição em papel da Edições e Publicações Brasil Editora S.A., São Paulo, 1959.

KAHLMEYER-METENS, Roberto. 10 Lições Sobre Gadamer, Petrópolis: Vozes, 2017.

LÖWY, Michael. A filosofia da história de Walter Benjamin. Palestra feita pelo autor em 28 de janeiro de 2002 na sede do Instituto de Estudos 
Avançados da USP. Disponível em: http://www.scielo.br/pdf/ea/v16n45/v16n45a13.pdf Acesso em 21 de janeiro de 2020.

OLIVEIRA, R. de P. Da Universalização do Ensino Fundamental ao Desafio da Qualidade: uma análise histórica. Educação \& Sociedade, vol.28, n¹00, pp. 661-690, 2007.

PALMER, Richard E. Palmer. Hermenêutica. Edições 70, LDA, Lisboa, Portugal, 2015.

PLATÃO. A República. Tradução Maria Helena da Rocha Pereira. 9. ed. Lisboa: Fundação Calouste Gulbbenkian, 2001.

Protágoras. Tradução de Carlos Alberto Nunes. Editora da Universidade Federal do Pará. 2002.

RÉE, Jonathan. Heidegger História e verdade em Ser e Tempo. Tradução de José Oscar de Almeida, Karen Volobuef. - São Paulo: Editora UNESP. 2000.

RIBEIRO, Djamila. O que é lugar de fala?. Belo Horizonte: Letramento, 2017.

RICOEUR, Paul. Interpretação e ideologias; organização, tradução e apresentação de Hilton Japiassu. Rio de Janeiro, F. Alves, 1977.

ROHDEN, Luiz. Filosofar com Gadamer e Platão - Hermenêutica filosófica a partir da Carta Sétima. 1.ed. São Paulo: Annablume Clássica, 2018.

SAMPAIO, M. das M. F. Aceleração de Estudos: uma intervenção pedagógica. Em Aberto, Brasília v. 1, n.71, p. 57-73, jan. 2000.

SAVIANI, D. Democracia, educação e emancipação humana: desafios do atual momento brasileiro. Psicol. Esc. Educ. vol.21, n.3 p.653-662. 2017.

. O paradoxo da educação escolar: análise crítica das expectativas contraditórias depositadas na escola. In: SAVIANI, D. O Lunar de Sepé Campinas: Autores Associados (p. 85-99) 2014.

SCHMIDT, Lawrence K. Hermenêutica; tradução de Fábio Ribeiro, 3.ed. - Petrópolis, RJ: Vozes, 2014.

SOUZA, Marcelo Gustavo Andrade de Tolerar é pouco? Por uma filosofia da educação a partir do conceito de tolerância. Rio de Janeiro, 2006. 315p. Tese (Doutorado em Ciências Humanas - Educação) Pontifícia Universidade Católica do Rio de Janeiro. 
VELASCO, Luiz Antonio Nolasco. Histórias de Cuspe e Giz. Seropédica, 2016. 116p. Dissertação (Mestrado) - Programa de Pós-Graduação em Educação, Contextos Contemporâneos e Demandas Populares. Universidade Federal Rural do Rio de Janeiro. 